\title{
Public and reputational sanctions: The case of cartels
}

\author{
Franco Mariuzzo $^{\mathrm{a}, \mathrm{b}}$, Peter Ormosi ${ }^{\mathrm{a}, \mathrm{c}}$, Zherou Majied ${ }^{\mathrm{d} 1}$ \\ ${ }^{a}$ Centre for Competition Policy, University of East Anglia, Norwich NR4 7TJ, UK \\ ${ }^{\mathrm{b}}$ School of Economics, University of East Anglia, Norwich NR4 7TJ, UK \\ ${ }^{\mathrm{c}}$ Norwich Business School, University of East Anglia, Norwich NR4 7TJ, UK \\ ${ }^{\mathrm{d}}$ Rayyan Al-Iraq Group, Baghdad, Iraq
}

January 29, 2020

\begin{abstract}
In this article, we revive an old debate in the law and economics literature: the relative role of public and reputational sanctions in deterring misconduct. We propose an empirical framework, which accounts for public sanctions (in our case cartel fines) and a more direct measure of reputational sanctions, harnessing recent developments in opinion mining. We use the intensity and the sentiment of media exposure of misconduct as a measure of reputational effect and thus approximation of the reputational sanction. As a demonstration, we combine an event study approach, sentiment analysis, and econometric techniques on a sample of 339 listed cartel member firms, prosecuted by the European Commission between 1992 and 2015. Our results offer evidence that in the context of cartels, public and reputational sanctions act as substitutes: where there is a reputational penalty, increasing this penalty reduces the effect of the public sanction. One the other hand, in the absence of a reputational punishment, the effect of the cartel fine steps in.
\end{abstract}

Key words: Cartels, event study, public sanctions, reputational sanctions, sentiment analysis

JEL Classification: L4, K4

\section{Introduction}

Most illegal behaviour faces two types of sanctions: a public sanction, fines imposed directly by an administrative body or the court; and a reputational sanction, which materialises indirectly through market mechanisms. The law and economics literature that studies reputational and public sanctions seems to

\footnotetext{
${ }^{1}$ Zherou Majied is a computer scientist, who worked at an original version of this paper during his master thesis at the University of East Anglia.

${ }^{\dagger}$ Paper presented at the $6^{\text {th }}$ EIEF-Unibo-IGIER Workshop on Industrial Organization, CCP Seminar Series, and 2019 CRESSE conference. The authors would like to thank Inna Danylyuk, Adam Halsey, Holly Hancock, Sam Leyshon-Garner, and Elena Mengo for valuable research assistance. A special thank to Morten Hviid, Antonios Karatzas, Evgenia Motchenkova, Andreas Stephan, and Catherine Waddams for their constructive comments. Finally, we are grateful for the comments from the journal's editorial and reviewer team, which significantly improved this paper.
} 
agree that reputational sanctions can deter corporate misbehaviour, inasmuch as the offenders internalise the social cost of the offences; and concords on the point that public sanctions are needed when the harm caused by the offence is not internalised.

An important upshot of previous literature is that reputational sanctions tend to work in contractual relationships, particularly, in repeated purchase settings. Klein and Leffler (1981), Shapiro (1983), and Lott Jr (1988) provide theoretical models where customers of a business change their custom in response to a breach in their contractual agreement. The literature distinguishes between 'related-party' and 'third-party' crimes to refer to behaviour that affects contractual parties (for example some cases of fraud, as in Karpoff and Lott Jr, 1993) and behaviour that impacts third parties (for example environmental violations, as in Karpoff et al., 2005). The credibility of the reputational sanction derives from the change in purchasing patterns that accompanies a variation in beliefs about the offence. In this case, some, or all costs of the damages caused by the misbehaviour can be internalised by the offending firm through its repeated contracting with customers, suppliers, employees, and investors. Reputational sanctions should be sufficient where the only damaged party is a customer of the unlawful business and the total amount of the damages are internalised by the offender. The above literature argues that in this setting public sanctions would only be required to the extent the reputational sanction does not encompass the total social cost of the offence.

Empirically, Peltzman (1981), Karpoff and Lott Jr (1993), Alexander (1999), Karpoff et al. (2008) studied how markets react to fraudulent or misleading behaviour. Jarrell and Peltzman (1985) and Mitchell and Maloney (1989) examined the reputational impact of product recalls (faulty products). Both of these behaviours are related-party conducts. Jones and Rubin (2001) and Karpoff et al. (2005) looked at environmental violations (a third-party offence). Their findings are in line with the theory: reputational sanctions are effective mostly in related-party offences, but less so in third-party offences, where therefore more reliance on public sanctions is warranted. Armour et al. (2017) provide further empirical evidence to 
this distinction.

One of the key difficulties in these previous empirical works is that too often reputational sanctions (and largely their determinants) are difficult to directly observe and measure, and this complicates the empirical evaluation of their effectiveness. To overcome this, previous works have used an indirect measure of this reputational impact by decomposing the share price effect of various corporate wrongdoings into: the effect of the public sanction, a readjustment effect (without the wrongdoing, profits are expected to be lower), and a residual which can be associated to reputational loss (see for example: Peltzman, 1981, Karpoff and Lott Jr, 1993, Alexander, 1999, Karpoff et al., 2008). This has been driven by the intuition that reputation is an intangible asset, the value of which is expressed as a component of the share price valuation of the business. In this setting, reputational loss is manifested by a stock price drop because the share price valuation reflects investors' expectations of loss in future profits at lower levels of reputation. This might entail expectations that future sales will drop, or that firms will have to spend on correcting measures (extra advertising or price drops) to mitigate the reputational damage.

In comparison to these previous works, we provide a more direct way to approximate the magnitude of the reputational effect. Recent developments in opinion mining and natural language processing allow us to extract the opinion in the media coverage of corporate offences, and to study the relationship between share price valuation and opinion (Van de Kauter et al., 2015). To the best of our knowledge, no such analysis has been conducted to investigate the relative effectiveness of public and reputational sanctions on firms' behaviour. The context of illegal cartels gives us an ideal ground to test our approach. When the regulator discovers a cartel, this information is not automatically distributed to all related parties (especially not to atomistic consumers). Various information channels are in action to pass the news on the cartel conduct to the public, and because without this information there would be no reputational impact, we posit that the reputational effect is directly related to the sentiment and the intensity of the information. 
Our proposal offers a workable, and easy-to-implement way to study reputational and public sanctions (in our case cartel fines). ${ }^{2}$ Information on public sanctions are directly obtained from administrative and court decisions, and reputational sanctions are approximated by the intensity and the sentiment of media exposure of the misconduct. We estimate the effect of these measures on the market valuation of offending firms. In this, we borrow from the work of Aguzzoni et al. (2013), which we use as a benchmark study, who employ a similar event study approach to estimate the impact of the public fine on firm valuation. Compared to theirs, we use an updated dataset, which includes the cases that were announced between the completion of their study and our own data collection. We first partly replicate their event study estimates of the effect of the public sanction. Our estimates, conducted independently of Aguzzoni et al. (2013) confirm their results. But then, as our main contribution, using our approximation of reputation, we also estimate the effect of reputational sanctions, and study the interaction between these and the public sanction, and how they impact on the cumulative abnormal rate of return of shares.

One of the main advantages of this approach is that data on the public, and our measure of private sanction are freely available. To demonstrate this, we use a publicly available dataset on EU cartels assembled by the European Commission (Commission), which we merge with a database on news articles that document and describe the illegal cartel (and cartel members) behaviour. We do a count of news sources per cartel member as indicator of exposure of each cartel member to the news, and then quantify the opinion of each news' item using sentiment analysis. Loss or gain in market valuation is used as a proxy for the deterrence power of these two types of sanctions.

Our approach also provides an opportunity to look at the relative role of public and reputational sanctions in deterring misconduct. Based on the premise that businesses are averse to falling market valuation, we assume that sanctions with larger negative effect on market valuation act as stronger deterrent. We then estimate the relative effect of public and reputational sanctions on firms' market valuation. If the

\footnotetext{
${ }^{2}$ For the purposes of this paper we look at a specific form of public sanctions, administrative fines, and therefore we use the two terms interchangeably.
} 
two are substitutes (complements), the marginal effect of public sanctions on firm performance will be reduced (augmented) by the effect of higher reputational sanctions. This follows the same logic as a number of previous theoretical models, such as in Karpoff and Lott Jr (1993). ${ }^{3}$ Ganuza et al. (2016) also offer a theoretical take on substitutability and complementarity between legal and reputational sanctions. Although their attention is on product liability, their model is highly relevant to us, as it is fundamentally a simplified version of the collusion model by Green and Porter (1984). They describe the conditions in which public and private sanctions are substitutes, and when they are complements. Moreover, they highlight the importance of public sanctions in circumstances where reputational sanctions are less effective (such as when the informational asymmetry is severe, the firms surplus from future trade is not large, or the time horizon of many market participants is not long) - in which cases the role of the legal system in encouraging trade becomes more relevant, perhaps essential.

Part of our results confirm the findings of Aguzzoni et al. (2013): cartel members are financially more hurt at detection than at decision, and fines have an impact on firm valuation in the proximity of the decision. The remaining results are new. Our main findings show that fines play a key role on a narrow window around the decision, while reputational sanctions reflect value losses on a larger time period. Using three different methods (estimating marginal effects, direct testing, and regression trees), we also offer support to previous theoretical findings, such as Ganuza et al. (2016), that the sentiment of media coverage and the fine imposed on the cartel act as substitutes (one's respective effect intensifies when the other's magnitude diminishes).

The paper proceeds with a description of the institutional setting. Section 3 introduces the various types of data sources needed for the study. In Section 4 we present the methodologies. Section 5 discusses the results and looks at whether public and reputational sanctions are substitutes or complements in deterring

\footnotetext{
${ }^{3}$ Iacobucci (2014) demonstrates in a theoretical setting that the size of the public sanction affects the size of the reputational sanction and larger fines are associated with larger reputational punishment. This is intuitive, as public attitude is likely to be influenced by news on the magnitude of sanction, which is perceived as directly proportional to the seriousness of the offence.
} 
misconduct, and offers a set of robustness checks. Section 6 concludes with a more general discussion.

\section{European cartels - institutional setting}

In the European Union the principal body in charge of investigating cartels is the European Commission (at national level the member state competition authorities enforce anti-cartel laws). The investigation can start following: (a) a complaint, (b) the opening of an own-initiative investigation, or (c) a leniency application from one of the participants to a cartel. After an initial investigative phase, the Commission decides whether to conduct an in-depth investigation - which typically starts with a dawn raid of the suspected cartel members' offices. This is the first point at which the fact of the investigation is publically announced. However, there is some possibility that investors anticipate the investigation even before this date. For example, it is not uncommon that a US cartel investigation is followed by an investigation in the EU.

Once the Commission reached its decision, it consults the national competition authorities, and then the final decision is adopted by the full College of Commissioners. The parties to the case are informed directly of the decision, and at the same time the Commission issues a press release on key details of the decision, which includes the amount of the fine imposed on each infringing firm. If the cartel was reported by one of its members (leniency application), the fine can be reduced for this particular firm. Similarly to Aguzzoni et al. (2013) our study focuses on these two main announcements, the start of the investigation, and the final decision, and their effect on firms' share prices.

Cartels are related party offences as it is the customer who directly suffers the harm, and therefore, based on previous literature, we would expect reputational sanctions to have a deterrent effect. ${ }^{4}$ However, when it comes to cartels, interestingly, the academic discussion on the optimum amount of fines typically circumvents the issue of reputational sanctions. Most discussion is limited to the optimal magnitude of the

\footnotetext{
${ }^{4}$ The literature on cartel deterrence in general is plentiful. In a comprehensive review, Marvao et al. (2018) take account of the relevant literature on the deterrent effect of various anti-cartel policies with a particular focus on leniency programmes.
} 
administrative or criminal fine, or the possibility of custodial sentences (see Polinsky and Shavell, 1984, Souam, 2001, Allain et al., 2015, among others). For monetary sanctions the argument is that, they should account for the total social cost of the cartel. Karpoff and Lott Jr (1993) argue that in the case of fraud this would lead to over-deterrence because it ignores the effect of reputational sanctions. For cartels, there seems to be an understanding that too high sanctions on cartel activity do not jeopardise pro-competitive conduct that could be mistaken for cartel activity; therefore, over-deterrence is not an issue. The law and economics literature on private sanctions would argue that neither public nor reputational sanctions should be studied individually on their own. Size and gravity of determinants of reputational sanctions are driven by the magnitude of public sanctions - in which case the public sanction acts as a signal to the gravity of the offence - i.e. without public sanctions, reputational sanctions would not be effective (Iacobucci, 2014). On the other hand, the effectiveness of public sanctions may depend on the presence of reputational sanctions and on the underlying environment. This would mean that for public sanctions to be effective they would have to be administered as part of a cocktail with reputational sanctions, and the relative dosage would depend on the context of the case.

\section{Data}

Our data is based on cartels that were prosecuted by the European Commission. The data consists of information on cartel characteristics and the list of companies that participated in the cartel activities. For the population of listed (public) cartel members we collated information on share prices and market performance, along with their capitalisation, before and after the Commission's detection and decision cartel dates. Finally, to gain insight on the possible reputational damage, we put together a dataset of media articles (newspapers, magazines and news agencies). We describe each piece of data source separately. 


\subsection{Cartel data}

We collected information on cartel characteristics, and dates of detection and decision for 150 European cartels convicted by the Commission during the period 1992-2015. The information is retrieved from public documents available on the Commission's website. ${ }^{5}$ The documentation includes cartels that operated in final or intermediary manufacturing and service industries. The sources that we have accessed are nonconfidential versions of decisions adopted by the Commission, including: summary decisions published in the Official Journal of the European Union - EUR-Lex, reports from the Hearing Officer, opinions of the Advisory Committee, Commission's press releases on adoptions of decisions and, where available, Commission memos on inspections, statements of objections or Court judgements.

Table 1: Cartel summary statistics

\begin{tabular}{lccccc}
\hline Variables & $\mathrm{N}$ & mean & $\mathrm{sd}$ & $\min$ & $\max$ \\
\hline & & & & & \\
cartel characteristic: & & & & & \\
convicted (year) & 150 & 2006 & 5.71 & 1992 & 2015 \\
coverage (market share) & 68 & 0.83 & 0.19 & 0.11 & 1 \\
detected (year) & 121 & 2002 & 6.31 & 1983 & 2014 \\
duration (years) & 103 & 7.77 & 6.29 & 0 & 34.8 \\
ring-leader (dummy) & 92 & 0.27 & 0.45 & 0 & 1 \\
size (N. members) & 103 & 7.34 & 8.13 & 2 & 76 \\
& & & & & \\
cartel type (non-exclusive): & & & & & \\
bid rigging & 109 & 0.18 & 0.39 & 0 & 1 \\
market share allotment & 109 & 0.63 & 0.48 & 0 & 1 \\
price fixing & 109 & 0.84 & 0.36 & 0 & 1 \\
quota allotment & 109 & 0.34 & 0.46 & 0 & 1 \\
N. cartels & 150 & & & & \\
Notes: This table shows summary statistics of cartel attributes. \\
The bottom panel describes types of cartels (categories are non- \\
exclusive).
\end{tabular}

A summary of cartel characteristics is offered in Table 1, which reveals a few things about missing observations. In particular, it was not possible to retrieve full information on the market coverage of the cartel, and on the existence of a ringleader for a number of cartels. For 29 cartels, we could not find any

\footnotetext{
${ }^{5}$ See http://ec.europa.eu/competition/elojade/isef/index.cfm [webpage last consulted September 2019].
} 
information on their characteristics. Nonetheless, for the cartels we have information on, we note that, on average, they lasted less than 8 years, were composed of about 7 firms, and covered $83 \%$ of the market. Over $80 \%$ of cartels involved price fixing, and two thirds of cartels had market share agreements. We only have information on the type of the cartel for 109 cases. $^{6}$

\subsection{Cartel member (firm-level) data}

Along with the cartel characteristics, we gathered details on the firms that participated in the cartel activity. The documentation provides information on the name of the firms that took part in the cartel, the fine that was charged before leniency was applied, the percentage of leniency reduction, and the new fine calculated after the leniency discount. An example of the information that is available is provided in Table 2 for the Air Cargo cartel, labelled in the Commission's documents as Airfreight cartel (convicted in 2010). Fourteen firms belonged to that cartel, of which Lufthansa (and its subsidiary Swiss Airlines) received full immunity from fines, as it was the first to apply for leniency and help with the cartel investigation.

Table 2: Airfreight cartel: Firm fines (in million Euros)

\begin{tabular}{llccc}
\hline Cartel & Firm & Fine before & \% of leniency reduction & Fine after \\
\hline Airfreight & Air Canada & 24.75 & 15 & 21.04 \\
Airfreight & Air France & 228.65 & 20 & 182.92 \\
Airfreight & British Airways & 115.60 & 10 & 104.04 \\
Airfreight & Cargolux & 94.00 & 15 & 79.90 \\
Airfreight & Cathay & 71.40 & 20 & 57.12 \\
Airfreight & Japan Airlines & 47.60 & 25 & 35.70 \\
Airfreight & KLM & 158.95 & 20 & 127.16 \\
Airfreight & LAN Chile & 10.28 & 20 & 8.22 \\
Airfreight & Lufthansa & 0 & 100 & 0 \\
Airfreight & Martinair & 59.00 & 50 & 29.50 \\
Airfreight & Qantas & 11.10 & 20 & 8.88 \\
Airfreight & SAS & 82.55 & 15 & 70.17 \\
Airfreight & Singapore Airlines & 74.80 & 0 & 74.80 \\
Airfreight & Swiss International Airlines & 0 & 100 & 0 \\
Total & & 978.66 & & 799.45 \\
\hline Notes: The table shows an example of fines and leniency applied to the Airfreight cartel.
\end{tabular}

The full dataset of cartel members accounts for 767 firms - $13 \%$ of these are recidivist but in industries

${ }^{6}$ Our sample excludes settled cases, as for most of the analysed period, settlement was not an option. 
that differ from the industry where the same firm had committed another offence. Some of these firms are publicly listed, and for these we collected information on their share prices around the detection and decision date, as discussed in the next section. To ensure that firm size does not play a role in estimating the effect of fine on the market valuation of cartel members, in our regressions we use a normalised form of fine: fine over market capitalisation.

\subsection{Stock market data}

A third dataset includes cartel members' share prices, their capitalisation and corresponding market value. We downloaded daily share prices (adjusted for dividends) for all listed firms in our sample from Datastream. We also downloaded daily prices for their respective home market index, as well as the market capitalisation in their home market. ${ }^{7}$ Daily prices spanned from one year before and one year after the detection and decision dates. For a small number of companies we could not retrieve share prices prior to the detection date (because they had not become public yet), and for an even smaller number we were unable to find data before the decision date (because the companies had been de-listed or bought out by that time). This selection mechanism produced a final sample of 339 publicly listed firms, which had share prices either around the raid or around the decision (or in most cases around both periods).

\subsection{Media articles}

The last fragment of data consists of news articles on the cartel and cartel member behaviour, downloaded from Nexis $\cap$ service of the LexisNexis information solution. Nexis $\cap$ aggregates information from a huge body of international news, business articles, business-relevant websites, blogs and forums.

The Nexis search engine accepts individual words or strings, and then identifies and retrieves the articles

\footnotetext{
${ }^{7}$ We used a major, broad, capitalisation-weighted index of the local (home) market of the firm (Campbell et al., 2010). For example, for British firms we used FTSE 100, for US firms we used S\&P 500, and so on. For developing countries with no data on such indices, we used the corresponding Datastream calculated index.
} 
that contain the specified word(s). For each cartel, we collated English written news that reported and described cartel behaviour during the time window: one day before and after the cartel decision. We opted for publications in the English language only. Although we were aware of the potential biases that this choice could introduce, we made our decision based on two premises: Firstly, it would be impractical, if not impossible, to include in our search string the translated terms "cartel" and "price-fix" in all languages. Secondly, not specifying the terms "cartel" and "price-fix" to allow for all languages would generate much noise (i.e. company-related news irrelevant to the cartel conviction decision). Furthermore, these news pieces can be in languages that we do not command, and distinguishing between relevant and irrelevant news releases would be an impossible endeavour. Finally, all the cartels in our sample are of international nature and were likely to have been reported by English language news sources.

Nevertheless, we did formally test if news articles covering companies from English speaking countries were over-represented in our sample. Looking at simple descriptive statistics, we found that the mean number of articles for English firms was 10.2 (standard deviation 13.1 and sample size 70 observations), whereas the same number for non-English firms was 9.2 (standard deviation 11.2 and sample size 216 observations); the mean sentiment score was -0.77 (standard deviation 0.38) for English, and -0.72 (standard deviation 0.39) for non-English firms. For neither of these two measures there is significant difference between sample means. Furthermore, we have also found that, after controlling for cartel fixed effects, the fact that a firm is English or not, did not have a significant impact on the number of articles on that firm, or the sentiment in these articles.

We searched Nexis according to the boolean rule: "name firm1" OR "name firm2" OR ... "name firm N" AND conjugations of "price fixing" OR "cartel". Using these two terms proved to be sufficient, as the EU press release invariably refers to all our cases as cartels, therefore we did not need to separately search for more specific definitions of the type of cartel (bid rigging, market allocation etc.). To verify this, we took a 
random sample of the bid rigging cartels and included the extra search term of various conjugations of the word "rig". The press articles we found all also contained the word cartel.

To be more inclusive, when appropriate, we employed both the original name of the company and its abbreviation with the use of the Boolean OR (e.g. "British Airways" OR "BA"). The period of the search was extended from the day before the official EU press release detailing the cartel conviction decision, to the day after. By including the day before the announcement we aimed at capturing media articles that discussed the imminent decision of EU on the day before (in case of any leakage of information). With the inclusion of the day after we aimed to capture printed news sources that were late in reporting the Commission's decision, either due to time zone differences or the fact that European newspapers are normally printed in the morning, hence may miss the EU decision on the day it takes place.

With our search rule, we gathered 1,534 different news articles. As a general rule, we aimed to keep all of these entries. The only reason texts were not included was when they were irrelevant - even the Nexis search engine produced a small number of articles that were not about the cartel. We also removed articles where the cartel-related news only made up a very small part of a longer piece. These were typically articles with lists of news items, with a short (often one line) entry on each item. In this case, the cartel related part of the 'article' was not only short and uninformative but was only one of a large number of unrelated items. We deemed these not useful for our analysis and discarded them. On the other hand, where the cartel was the primary focus of an article (no matter how short) the text was included. ${ }^{8}$ Texts from the original article were copied across exactly as they were (with typing/grammatical errors left in place).

Articles typically differ in length, the number of firms they list, and in the opinion they deliver to the reader. There is also variation in length (and content), and in the number of firms (companies) that are cited. ${ }^{9}$

\footnotetext{
${ }^{8}$ Five cartels have fallen off the articles watch list: 1) Cewal, Cowac and Ukwal, 2) Quantel International, 3) Reinforcing bars (Italy), 4) Sodium Gluconate, 5) Trans-Atlantic Conference Agreement.

${ }^{9}$ Take the Banana cartel (convicted in 2008) as an example: 15 news articles covered that cartel (see Table B.1) For the Banana cartel, there is limited variation in the number of firms mentioned in texts, but this is not necessarily a pattern of other cartels.
} 
Articles may cite a single company, multiple companies or no companies at all, as it happens when articles do not mention any company name, and talk only about the cartel.

One difficulty in combining the datasets was that there was no uniform convention in naming the firms. While it was not much of a problem merging the Commission and share price datasets, it was challenging to cope with the news article data, as there, the same firm was named differently in alternative news articles. This complicated the identification of unique firms within the same cartel and the merging of news articles with the other databases. For example "British Airways", appears shortened as "BA", or with a dash "British-Airways" or in modified versions, such as "British Airway" or "BritishAirway". Additional complexity was to deal with non-English firm names, such as "Société des Industries Chimique du Fluor" or

"Novácke Chemick Zvody and 1.garantovaná". We addressed this challenge by constructing a dictionary of combinations of firm names. By finding the matching firm names, we managed to retrieve 728 observations of firms (a small proportion of which are recidivist firms) out of the original Commission's database of 767 firms. Of those firms, 339 are publicly listed and have data around either or both raid and decision periods.

\section{Methodologies}

In this section, we give an overview of the three main methodologies used in our analysis: event study, opinion mining (sentiment analysis), and regression analyses.

\subsection{Event study}

Though a key tenet of event studies, the efficient market hypothesis literature, introduced by Fama (1965) and then extended by Malkiel and Fama (1970), has been criticised by behavioural finance (Kahneman and Tversky, 1974, Shiller, 1981), its core - that information integrates into share prices immediately - 
still remains a principle widely accepted in the business, economics and finance literature. ${ }^{10}$ As a result, event studies have been used to address a wide variety of research questions. Closest to our work are those event studies that look at the market impact of corporate misbehaviour, such as environmental violations (Laplante and Lanoie, 1994, Hamilton, 1995, Graddy and Strickland, 2007), fraud (Karpoff et al., 1999, Fich and Shivdasani, 2007), or the market impact of corporate social responsibility (McGuire et al., 1988). Aguzzoni et al. (2013) conduct a set of event studies to look at the magnitude of abnormal rate of return at the time of various events in cartel investigations (announcements of dawn raids, final decisions, and appeal decisions). Given the overlap with their work, we decided to follow their approach in how we conducted our own event study. Replicating the Aguzzoni et al. (2013) paper not only gives us a solid starting point to pursue our own, different research question, but such replications have important academic value on their own right. Our choice of method is also supported by the argument that event studies are likely to perform well in short event window studies, such as ours (Kolari and Pynnönen, 2010). Finally, our interest lies not in the exact magnitude of the abnormal rate of returns, rather in the relative changes triggered by the two types of sanctions. Therefore, even if event studies provide biased results as to the magnitude of the effect of the event on abnormal rate of returns, unless the bias varies across public and private sanctions, the method should be useful for our research question.

To conduct our event study, we calculate the firm and market index returns by taking a first difference of the corresponding log share prices. We use the market model (see Brown and Warner, 1980, 1985) to obtain a counterfactual return, and then employ a standard event study methodology (MacKinlay, 1997) to compute the daily abnormal rate of returns (AR) for individual firms, and their cumulative version (CAR) over a number of different event windows.

Given that part of our data overlaps with that in Aguzzoni et al. (2013), we benchmark our results to theirs

\footnotetext{
${ }^{10}$ In a 2007 paper Kothari and Warner (2007) refers to over 500 such peer-reviewed studies. Bruner (2002) reviews over 100 published event studies on mergers and acquisitions.
} 
(see Tables B.5 and B.6 in the appendix for a throughout comparison). ${ }^{11}$ The window for CAR spans from 10 days before the detection or decision dates, to 10 days after ( 21 days in total). The null hypothesis that the cumulative abnormal rate of return (CAR) is zero is tested against the alternative that is greater than zero-this is tested based on the adjusted Boehmer, Musumeci and Poulsen's (1991) (BMP) test (see Kolari and Pynnönen, 2010). This test has the advantage of accounting for cross-sectional correlation, while being robust to serial correlation.

\subsection{Sentiment analysis}

Recent developments in text analysis contribute to the event study literature with sophisticated tools able to produce richer secondary data to study the relationship between share markets and opinion (Van de Kauter et al., 2015).

Opinion mining is the process of extracting useful information from unstructured data, such as text documents, e-mails and HTML files. Various non-exclusive techniques have been developed in the literature to study unstructured texts (see for example, Hotho et al., 2005, Gupta and Lehal, 2009, Gonçalves et al., 2010, Vijayarani et al., 2015). We use sentiment analysis (opinion mining) to understand the sentiments (or opinions) being presented in media reports. Sentiment analysis is the computational analysis of the opinion, sentiment, and subjectivity in a text. This is done by speech tagging: breaking down the semantic structure of sentences and determining which emotional words apply to a given keyword. Sentiment can be derived using a lexicon, which contains lexical units of a given language, and the sentiment associated to them.

We use a simple binary sentiment value, where words or combinations of words are assigned one of the following three polarity values: -1 for negative, 0 for neutral, and 1 for positive sentiment. A sentiment lexicon would contain, for a number of words (or combination of words), the corresponding sentiment.

\footnotetext{
${ }^{11}$ There is some misalignment in the results, because Aguzzoni et al. (2013) took the index of the market where the firm had the highest market capitalisation, whereas we have chosen the local market as we expected it to be more affected by the media coverage.
} 
There are a large number of sentiment lexicons available. ${ }^{12}$ For the purposes of this paper, we rely on two different lexicons. One of them is the word polarity dictionary composed by Hu and Liu (2004), which contains around 6800 positive and negative opinion words or sentiment words for the English language, which is also part of the R package sentimentr. This dictionary is optimised for customer product reviews, and is a fairly general set of sentiment scores. We use it as an approximation of how a layperson would interpret a general business related news item (below, we refer to this as 'general' lexicon).

On top of this, we also employ an augmented version of the same dictionary, where we use a modified dictionary in order to capture how subjectivity changes in a specific topic such as that of cartels. We did this through induction. First, we looked at the 600 most frequent tokens (words, bigrams, and trigrams ${ }^{13}$ ) in the corpus of news articles in our sample. Then the authors of this paper scored these tokens, based on their field specific knowledge of whether each of these are positive, negative or neutral. We then did the same exercise asking a team of colleagues/students at the Centre for Competition Policy, all of whom are knowledgeable in the field of competition policy and cartels. From them we received another 8 sets of sentiment scores. For each token we then took the mode of the individual sets of scores. Our cartel-specific dictionary with the 10 individual sets of scores is available online. ${ }^{14}$

We had two main reasons for using a customised lexicon. First, dictionaries, trained on general data such as product or movie reviews, are less likely to contain domain specific words that are relevant to our analysis (e.g. cartel, collusion, price fixing). Second, we wanted to reflect the difference between the assumed sentiment of a layperson (captured by the general lexicon), and someone who is familiar with the gravity of cartel behaviour (custom lexicon), when reading cartel-related news coverage. If we can show that being more aware of the seriousness of cartels (i.e. more negative sentiment scores) have a larger impact on the valuation of businesses, that would be an important policy message that improving competition

\footnotetext{
${ }^{12}$ We experimented with a number of these, results are available from the authors.

${ }^{13}$ Bigrams and trigrams are pair, or trio of consecutive words.

${ }^{14}$ https://github.com/Peterormosi/private_v_public_sanctions.
} 
culture (the public awareness of anti-competitive actions and their effects) can improve the deterrent effect of competition policy. For this purpose, in our robustness checks (Section 5.4) we also experiment with making the custom sentiment scores more skewed to assign even larger weight to very negative words.

The sentiment analysis was conducted in $\mathrm{R}$ using the packages qdap and sentimentr. A polarity (sentiment) score was calculated for each article, based on our sentiment lexicons (general and custom). ${ }^{15}$ This generated a set of article-level sentiment scores. As expected, the great majority of the articles produced a negative score. ${ }^{16}$ The density of the sentiment of firm-cartel-news articles is represented in Figure B.2. The density curves confirm that using the custom lexicon gives more negative interpretations of the same article than using the general lexicon. ${ }^{17}$

We also list the cartels that were most negatively covered by the press in Table 3 , using our own custom cartel-dictionary and the general polarity lexicon. The Car-glass, Airfreight, and the Banana cartels are among the top of the list for both dictionaries. ${ }^{18}$

\subsection{Classic regression}

In much the same way to Jarrell and Peltzman (1985), Karpoff et al. (2008), and Aguzzoni et al. (2013) we regress the cumulative abnormal rate of return (in percentage) at the time of the decision on the public sanction (fine) and on our measures of reputational sanction (media exposure and sentiment) and their interaction, among other controls.

The fine $(F)$ is our measure of public sanction, inflicted by the Commission and normalised by market capitalisation. ${ }^{19}$ We deduct leniency reductions from the figure reported by the Commission.

\footnotetext{
${ }^{15}$ The formula used for calibrating the article-level scores is given in: https://rdrr.io/cran/sentimentr/man/sentiment. html.

${ }^{16}$ We excluded the amount of fine from the analysed texts to ensure that the scores reflect the sentiment only.

${ }^{17}$ Whereas the support of our sentiment lexicon is $[-1,1]$, the support of the calibrated sentiment scores is more spread out.

${ }^{18}$ We have also experimented with the stemming technique. We exerted the stemming procedure to both the lexicon and the words from our articles. The stemming methodology brought in new challenges as we had words with the same linguistic root and parts of the speech, but completely different sentiment in the lexicon. For this reason, we found this methodology unsuitable for the purpose of our analysis.

${ }^{19}$ This normalisation follows Aguzzoni et al. (2013) and is aimed at indirectly controlling for firm size.
} 
Table 3: Most negatively presented cartels (sentiment weighted by exposure)

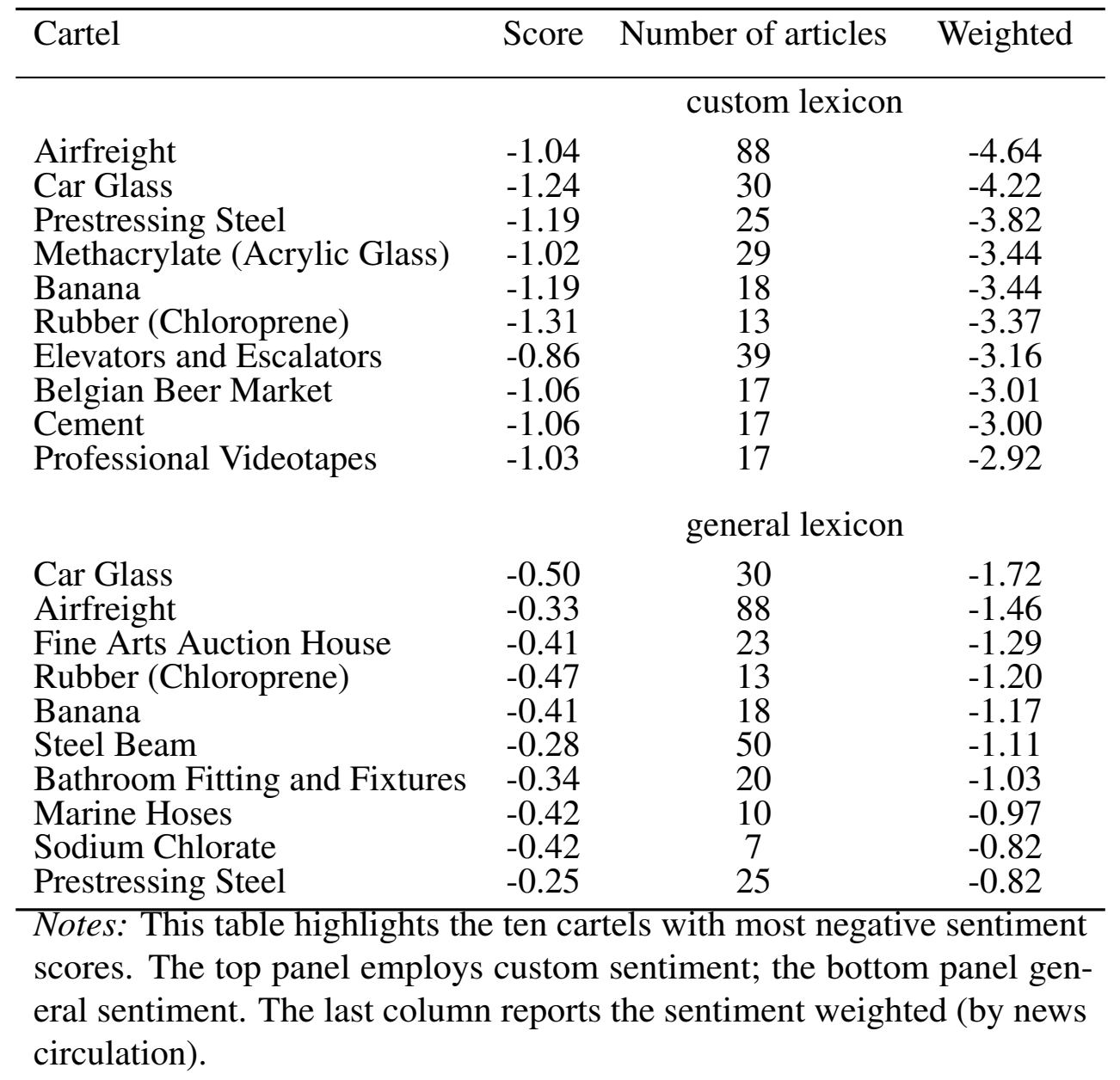

Reputational sanctions are proxied by two measures. The first one is media exposure $(E)$, which is given by the number of articles documenting a cartel member misconduct. We considered accounting for the fact that not all articles have the same exposure. For this, first we collected circulation data for each news source, where it was available. This raised a number of issues. First of all, there is no circulation data for newswires (many of the articles in the sample are newswires). Second, circulation numbers are typically only available for printed press, but most exposure is likely to happen through online news. Online circulation is not consistently reported and even where it is, these numbers are highly volatile, circulation can change dramatically within a few years. Acquiring a time series of circulation data for each news source, to match our articles was simply not possible given the lack of such data.

For this reason, we decided against including speculative circulation information in our analysis and used 
unweighted exposure. However, as a robustness test, presented in Section 5.4, we look at the geographical (country or continent) coverage of our news sources (as reported by Nexis.com). We then linked this coverage information with the corresponding population size data, and categorised geographical coverage into three groups (small, medium, and high). We used these as weights for our measure of exposure. As a further weight we also included whether the news source was from an English speaking country. The reason we did this was because many developing countries would have large populations, but it is less likely that their press is widely read outside these countries.

Finally, our second proxy of reputation is the average (by firm) sentiment of these articles $(S)$. Although intuitively it might appear that the exposure and the sentiment in news coverage are likely to be positively correlated with the magnitude of the fine, this does not seem to be the case. The pairwise correlation coefficient between the fine and exposure is -0.017 , and between fine and sentiment is -0.009 . The lack of correlation is likely due to the fact that we normalise fine to eliminate the issue that large firms by definition receive larger fines.

The econometric equation for the cartel member (firm) $j$ is:

$$
C A R_{j}=g\left(E_{j}, F_{j}, S_{j}\right)+x_{j} \beta+\varepsilon_{j}, \quad j=\{1,2,, \cdots, J\} .
$$

The row vector $x_{j}$ includes the control variables: number of cartel members, cartel duration, dummy for observations with no data on cartel duration, dummy for recidivist firm, dummy indicating whether the firm received leniency, time trend, and firm market capitalisation (proxy for firm size). The notation employed in Equation (1) suggests that the dataset is cross-section, but the presence of recidivist firms would have made a panel notation more appropriate; however, as only $13 \%$ of the firms are recidivist, we maintain the light touch cross-sectional notation. ${ }^{20}$

\footnotetext{
${ }^{20}$ For example, Atochem and Akzo appear in the original dataset 9 and 7 times, respectively.
} 


\subsection{Regression tree}

A common goal of many research studies is to classify observations into important categories but traditional econometric methods offer limited use to classify data. One of their main drawbacks, is that there are many possible "predictor" variables and this makes the task of variable selection difficult, if not impossible. In addition, the predictor variables are rarely nicely distributed and often require complex interactions or patterns, which are typically difficult to model. Classification and regression tree (CART) methods are often summoned in cases where the underlying research question is on the relative importance of the different predictors in driving an outcome variable - similar to the question we have at hand. ${ }^{21}$ In solving these problems, the regression tree approach is a simple way to represent the relationship between our measures of public and private sanctions, and the variable of interest, the percentage of cumulative abnormal rate of return at different time windows. A tree consists of a root node (node 1), containing all observations. This node is split into branches and leaves (end nodes) based on the value of predictors. The regression tree algorithm does segment the predictor space into a number of regions and within each leaf it calculates the average predicted value and percentage of the training observations within that region. The variable that determines node 1 is the most important variable for the classification.

\section{Results}

\subsection{Estimating the abnormal rate of returns}

First, we discuss the predicted abnormal rate of returns (AR) and then address the effect of reputational and public sanctions on the cumulative average abnormal rate of returns (CAAR). Table 4 displays the average AR from 10 days prior to the event, to 10 days after the event, where the event represents either the raid or the decision about the cartel conviction. The table also reports the p-value of one-tailed test $J$-statistic (the

\footnotetext{
${ }^{21}$ CART analysis is a tree-building technique, which is suitable when the outcome (dependent) variable is continuous.
} 
aforementioned BMP test).22

Table 4: Predicted abnormal rate of return at the raid and at decision (\%)

\begin{tabular}{|c|c|c|c|c|}
\hline & \multicolumn{2}{|c|}{ Raid } & \multicolumn{2}{|c|}{ Decision } \\
\hline & $\begin{array}{l}\text { Mean } \\
\text { (1) }\end{array}$ & $\begin{array}{l}\text { J p-val } \\
(2)\end{array}$ & $\begin{array}{l}\text { Mean } \\
\text { (3) }\end{array}$ & $\begin{array}{l}\text { J p-val } \\
\text { (4) }\end{array}$ \\
\hline Days to event & & & & \\
\hline-10 & 0.036 & 0.343 & -0.097 & 0.487 \\
\hline-9 & $-0.629^{a}$ & 0.002 & -0.203 & 0.173 \\
\hline-8 & 0.218 & 0.113 & 0.047 & 0.491 \\
\hline-7 & 0.241 & 0.184 & -0.109 & 0.171 \\
\hline-6 & $-0.456^{b}$ & 0.031 & -0.192 & 0.145 \\
\hline-5 & 0.101 & 0.288 & 0.034 & 0.411 \\
\hline-4 & -0.049 & 0.348 & 0.038 & 0.326 \\
\hline-3 & -0.199 & 0.487 & -0.087 & 0.156 \\
\hline-2 & 0.289 & 0.142 & -0.175 & 0.108 \\
\hline-1 & 0.180 & 0.244 & -0.157 & 0.196 \\
\hline 0 & $-0.846^{c}$ & 0.073 & $-0.348^{c}$ & 0.091 \\
\hline 1 & $-0.503^{a}$ & 0.009 & -0.193 & 0.322 \\
\hline 2 & $-0.279^{c}$ & 0.074 & 0.066 & 0.163 \\
\hline 3 & -0.061 & 0.476 & 0.065 & 0.453 \\
\hline 4 & $0.582^{c}$ & 0.071 & -0.229 & 0.187 \\
\hline 5 & -0.156 & 0.483 & -0.031 & 0.468 \\
\hline 6 & 0.234 & 0.256 & 0.016 & 0.289 \\
\hline 7 & -0.193 & 0.360 & -0.024 & 0.406 \\
\hline 8 & -0.105 & 0.288 & -0.034 & 0.326 \\
\hline 9 & -0.214 & 0.273 & -0.171 & 0.174 \\
\hline 10 & 0.109 & 0.264 & $-0.355^{c}$ & 0.075 \\
\hline
\end{tabular}

Event window

CAAR

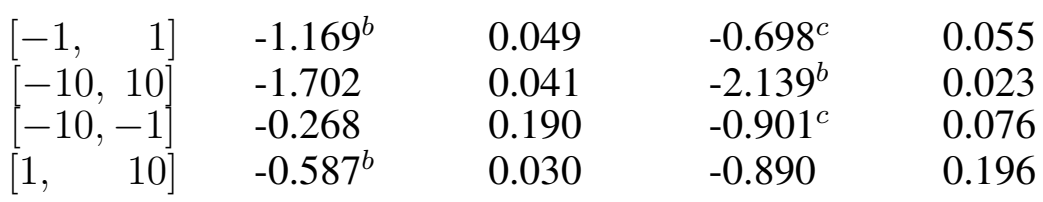

Obs. $\quad 194 \quad 315$

Notes: This table shows the average abnormal rate of return (AAR) and its cumulative version (CAAR) from ten days prior to the event to 10 days after the even, where the event is either the raid or the decision. Columns (2) and (4) document the one-tailed p-value of the BMP test (J-statistic). Significance levels: ${ }^{a} 1 \%,{ }^{b} 5 \%$, and ${ }^{c} 10 \%$.

The average AR is negative and mildly significant both at the day of the raid, and at the day of the decision.

The drop in share prices is more accentuated at the raid, $0.846 \%$, than at decision, $0.348 \%$. There are a couple of mildly significant drops in returns 6 and 9 days prior to the raid. The largest reduction occurs 9

\footnotetext{
${ }^{22}$ The abnormal rate of return estimation is conducted using the Stata package event study2, written by Kaspereit (2016).
} 
days before the raid. This is not what one would expect as raids are supposed to be secret and therefore unanticipated. Aguzzoni et al. (2013) have investigated this anomaly; ${ }^{23}$ adding to their interpretation, we believe this could be due to three effects:

1. The leniency effect: A dawn raid might be the consequence of a previous leniency application by one of the cartel members. In these cases it is likely that individuals within the confessing firm will start tipping others off that an investigation is on the horizon-especially after that firm has secured its place as first in line for immunity.

2. The domino effect: Although competition authorities typically portray cartel investigations as separate instances of enforcement success, they usually occur in waves within interconnected industries (e.g. chemicals, banking, car components). ${ }^{24}$ For example, for a large part of our sampled period (late 1990s through to around 2014), each of the chemicals cartels were dealt with in the US and in the EU. On the national level, similar examples include waves of bid-rigging cases.

3. The failed cartel effect: Many leniency applications materialise after the cartel had failed for other reasons. If this is the case, leniency applications are a race to avoid/diminish punishment (Harrington Jr, 2008). Whatever is driving this race, it will quickly be common knowledge in the industry that dawn raids are very likely or inevitable.

Consider all of these potential reasons against the fact that around $2 / 3$ of cartels are detected by leniency to make our findings even less surprising.

We do not find a sharp drop in the CAAR around the decision date, as highlighted in the third column of Table 4. This finding replicates the findings in Aguzzoni et al. (2013), and we side with their interpretation

\footnotetext{
${ }^{23}$ They dropped cases that had previously been investigated in the US or where leniency had been applied to the cartel, but found that results were even worse (i.e. more accentuated drop in prices prior to the raid) when these problematic observations were removed.

${ }^{24}$ For a concise summary, see Stephan (2008).
} 
that this is probably due to the fact that the decision adds little information to the negative anticipation of a cartel being busted, which is already well known to the market ahead of the final decision.

Anticipation of a cartel investigation is confirmed by a graphical inspection of the trend of the cumulative average abnormal rate of return captured by the dotted line in Figure 1, which shows a drop in the CAAR around the raid (calculated as sum of AAR from 10 days before the event to the each date on the horizontal axis; for example $\mathrm{CAAR}_{[-4]}=\sum_{t=-10}^{-4}=A A R_{t}$ ). The CAAR for the decision dates has a similar trend, but is smoother than CAAR for detection - with a less pronounced decline around the decision date (i.e. with larger anticipation effect).

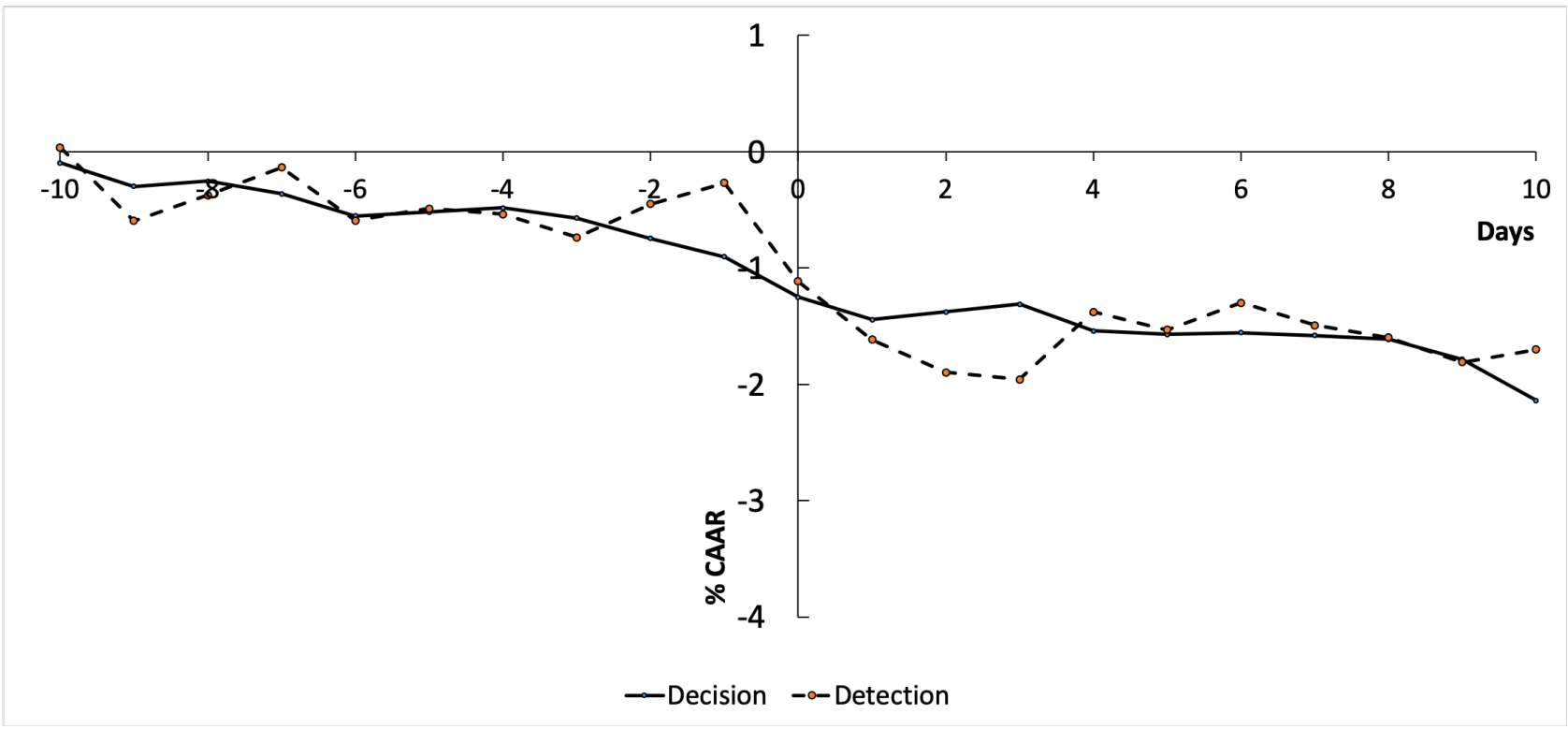

Figure 1: \% CAAR at detection (raid) and at decision. Notes: The figure shows the CAAR around the cartel detection and decision. The analysis is limited to \pm 10 days of the event.

The analysis of the CAAR displayed on the bottom panel of Table 4 shows that share prices significantly (or mildly significantly) drop around the raid. By looking at the $[-10,10]$ event window, the model predicts that the cartel decision deflates prices by $2.139 \%$, of which $-0.698 \%$ is cumulated in the immediacy of the decision ( \pm 1 day). The CAAR windows suggest that there is a mild effect on share prices in the immediacy of the decision, but of course this is an average effect. There are firms whose cumulative share prices \pm 1 
day of the decision is largely positive (top $1 \%$ cumulative abnormal price is $+9.47 \%$ ), and firms where the effect on share prices is substantially negative (bottom $1 \%$ cumulative abnormal price is $-17.87 \%$ ). The standard deviation is $4.34 \%$. This heterogeneity is further exploited in the next section.

\subsection{The impact of public and reputational sanctions}

We regress the (percentage) cumulative abnormal rate of return (CAR) for four time intervals $([-1,1]$, $[-10,10],[-10,-1],[1,10])$ against a set of control variables and the three key variables, the public fine ( $F$, normalized to market capitalization), the magnitude of media exposure of the offence $(E)$, and the calibrated sentiment of the media coverage $(S)$. The analysis is only conducted at the decision date because very few (in most cases zero) media articles were published around the raid. ${ }^{25}$ For measuring sentiment, we used our custom (domain-specific) dictionary, as explained above.

We have information on the CAR for 300 (out of 339) publicly listed firms, but 13 observations were not suitable to be included in the analysis, as, in our data, they presented a value of fine (over market capitalisation) in excess of $30 \%$, which we suspect to be a reporting error. We thus dropped these observations. There was no information on cartel duration (and other characteristics) for 35 observations. Instead of dropping these observations, we added a zero to duration and additionally included the dummy variable missing cartel duration to account for this lack of information. The number of observations we used for our estimates was therefore 287.

The regression results for the event windows $([-1,1],[-10,10])$ are reported in Table $5 .{ }^{26}$ To ease the interpretation of these results, $E, F$, and $S$ have been standardised. Columns (1)-(2) in the top panel are linear regressions of different time windows of CAR without controls, and columns (3)-(4) are the results with controls. The fine imposed on cartel members appears to negatively affect share prices in the proximity

\footnotetext{
${ }^{25}$ The time trend of the four key variables is plotted in Figure B.1 in the Appendix. The public fine is shaped as inverted U, while sentiment is a declining function, suggesting that the news articles have over time described more negatively the firm-cartel illegal cartel behaviour.

${ }^{26}$ We present more time windows in our Tables in the Online Appendix.
} 
of the decision ( \pm 1 day), whereas sentiment is key for the wider time window, with negative sentiment leading to negative abnormal return, and positive sentiment associated with positive CAR. ${ }^{27}$

Looking at these result alone, they would suggest that there is a genuine 'shock' response to announcement of a public fine in the market (similar to the findings in Aguzzoni et al., 2013). Moreover, for those cases where the media coverage is strongly negative, the market incorporates this information into the market valuation of the cartel members.

A central question in the law and economics literature is whether public and reputational sanctions are substitutes or complements in their deterrent effect. Karpoff and Lott Jr (1993) and Ganuza et al. (2016) argue that public and reputational sanctions are non-perfect substitutes in this respect. To contribute to this literature, as a next step, we looked at the interactions between our main variables of interest (shown as the bottom panel of Table 5). Through this we intend to account for possible non-linearities and answer the question on complementarity and substitutability between reputational and public sanctions.

To interpret the interaction coefficients in Table 5 it is easiest to fix one of our three variables of interest. For this we first fix the value of the sentiment score at the $5^{\text {th }}$ percentile, which is a very negative sentiment score (see Figure B.2) and look at the results with the wider event window, where we picked up a significant effect of the sentiment of media coverage. With $S$ fixed, our attention turns to how a change in exposure changes the effect of the fine. Two interaction coefficients are relevant for this, $E F$ and $E F S$. The coefficient of EFS dominates the coefficient of EF. A negative $S$ cancels out the negative sign of the $E F S$ coefficient, therefore as exposure $(E)$ increases, the negative effect of fine diminishes.

Now fix the sentiment score at its $95^{\text {th }}$ percentile, which means a positive $S$ (its non-standardised value close to zero). In this case the interaction term EFS becomes negative, the same as the sign of the

\footnotetext{
${ }^{27}$ In the appendix we reproduce the results in Table 5 by using the "general" measure of sentiment and note that the role of sentiment is less powerful (see columns 1 and 2 in Table B.3). We also replicate Table 5 by employing cartel fixed effects. Columns 9 and 10 in Table B.3 show that after controlling for cartel fixed effects most of the effects of public and reputational sanctions disappear; this mainly due to the fact that the news articles are at the cartel level and cartel member variations of sentiment and exposure are driven by the news articles documenting different firms.
} 
Table 5: Regression analysis of percentage CAR (polar custom score)

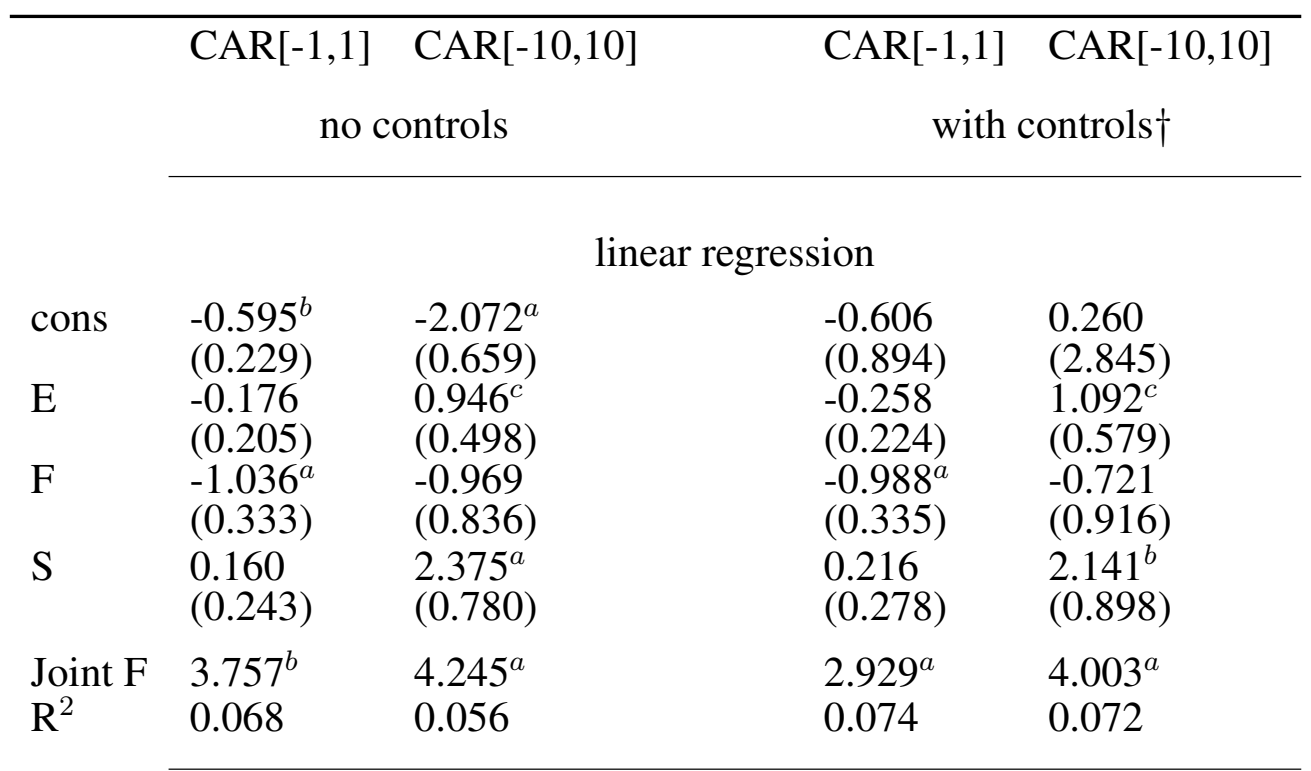

linear regression with interactions

\begin{tabular}{|c|c|c|c|c|}
\hline cons & $\begin{array}{l}-0.593^{b} \\
(0.252)\end{array}$ & $\begin{array}{c}-2.480^{a} \\
(0.698)\end{array}$ & $\begin{array}{l}-0.523 \\
(0.898)\end{array}$ & $\begin{array}{l}0.706 \\
(2.901)\end{array}$ \\
\hline $\mathrm{E}$ & -0.245 & 0.228 & -0.317 & 0.366 \\
\hline & $(0.246)$ & $(0.595)$ & $(0.282)$ & $(0.671)$ \\
\hline $\mathrm{F}$ & $\begin{array}{l}-1.203^{a} \\
(0.334)\end{array}$ & $\begin{array}{l}-1.661^{c} \\
(0.885)\end{array}$ & $\begin{array}{c}-1.147^{a} \\
(0.340)\end{array}$ & $\begin{array}{l}-1.416 \\
(0.915)\end{array}$ \\
\hline S & 0.176 & $1.775^{b}$ & 0.207 & $1.592^{c}$ \\
\hline & $(0.272)$ & $(0.813)$ & $(0.297)$ & $(0.876)$ \\
\hline $\mathrm{EF}$ & -0.241 & -1.239 & -0.232 & -1.364 \\
\hline & $(0.482)$ & (1.186) & $(0.494)$ & (1.158) \\
\hline $\mathrm{ES}$ & -0.007 & $-1.389^{c}$ & -0.047 & $-1.456^{c}$ \\
\hline & $(0.272)$ & $(0.775)$ & $(0.294)$ & (0.837) \\
\hline FS & $\begin{array}{l}-0.161 \\
(0.382)\end{array}$ & $\begin{array}{l}-0.329 \\
(1.216)\end{array}$ & $\begin{array}{l}-0.141 \\
(0.400)\end{array}$ & $\begin{array}{l}-0.230 \\
(1.199)\end{array}$ \\
\hline EFS & $\begin{array}{l}-0.732^{b} \\
(0.369)\end{array}$ & $\begin{array}{l}-2.955^{c} \\
(1.715)\end{array}$ & $\begin{array}{l}-0.683^{c} \\
(0.386)\end{array}$ & $\begin{array}{l}-2.936^{c} \\
(1.669)\end{array}$ \\
\hline Joint F & $2.421^{b}$ & $4.137^{a}$ & $2.329^{a}$ & $4.562^{a}$ \\
\hline $\mathrm{R}^{2}$ & 0.076 & 0.080 & 0.080 & 0.097 \\
\hline Obs & 287 & 287 & 287 & 287 \\
\hline
\end{tabular}


interaction term $E F$ (although this is not significant). This implies that as exposure $(E)$ of more positive news increases, the negative effect of fine also increases. Both of these effects seem more pronounced for the wider event window. How much the magnitudes of the coefficients matter? It is difficult to decide based on the coefficients alone, as we are more interested in the joint effect (and joint significance) of each relevant component of our interaction terms. Therefore for better understanding we visualise the estimates from Table 5.

In Figure 2 we plot the marginal effect of an increase in fines on the percentage cumulative abnormal rate of return, at various levels of media exposure and sentiment. As fines are standardised, a unitary increase in fines is equivalent to one standard deviation increase. Figures 2(a),(c) show the case where exposure has a very negative sentiment $\left(5^{\text {th }}\right.$ percentile) and Figures $2(\mathrm{~b})$,(d) show the marginal effects when news coverage has a neutral/positive sentiment ( $95^{\text {th }}$ percentile). The horizontal axes on each sub-figure show the level of media exposure.

These figures make it clearer what is happening in the relationship between media sentiment/exposure and the public fine. First of all, if the sentiment is negative, and exposure is very low, the marginal effect of the fine is negative (larger fine, larger loss in market valuation). Put differently, for a cartel that is normally seen negatively by the knowledgeable public (negative sentiment), if businesses are not exposed much on the media pillory, then the only thing that affects the market valuation of the misbehaving business is the amount of fine they receive. As soon as there is larger exposure of the negative sentiment, the public fine loses its effectiveness.

If the sentiment is neutral or positive (i.e. the public is not as negative about the cartel), then at low media exposure the public sanction does not seem to have a negative effect but as the exposure of neutral/positive sentiment increases, the effect of the fine becomes more negative. This result holds both in the proximity of the decision and maintains the direction in a wider window around the decision. Therefore the public 


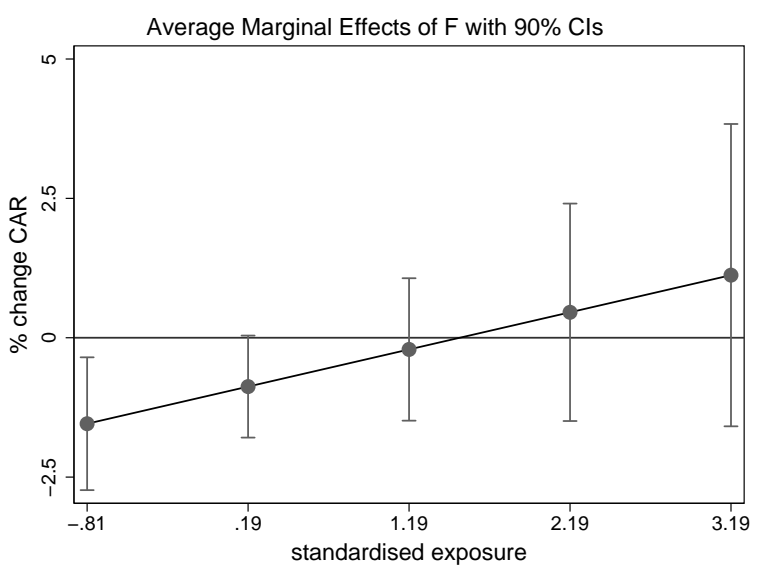

(a) Negative sentiment (CAR[-1,1])

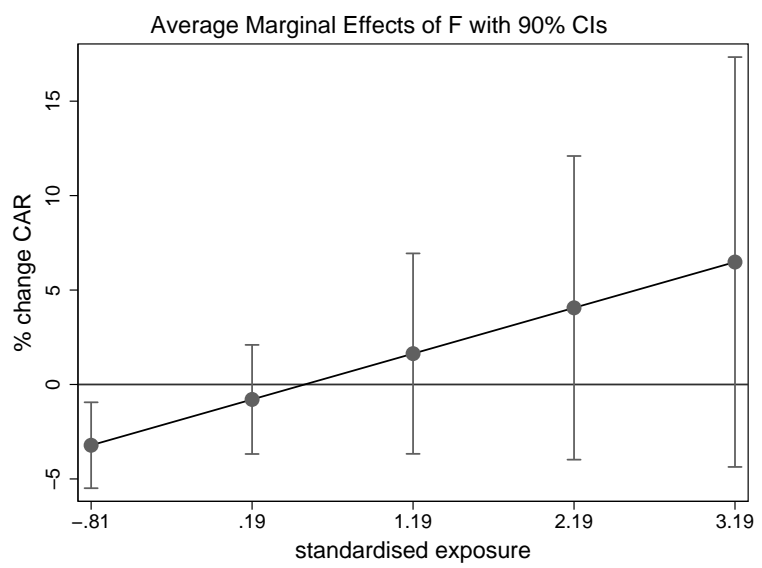

(c) Negative sentiment CAR[-10,10]

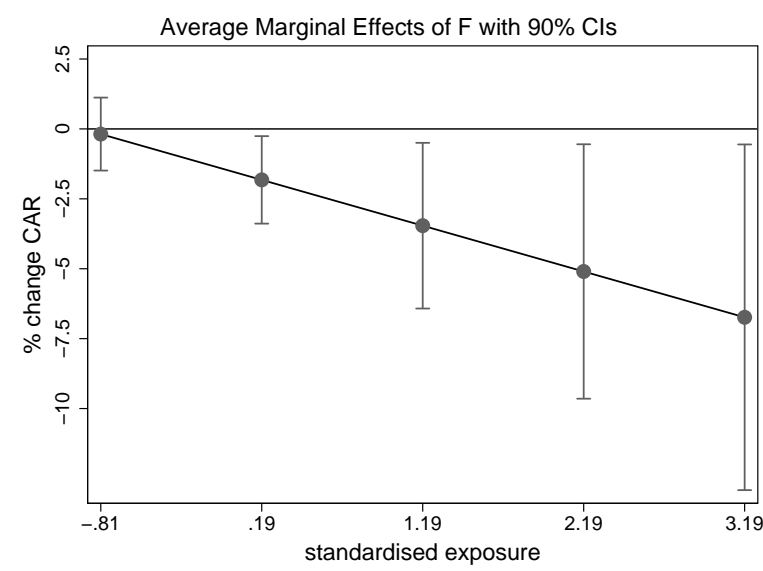

(b) Neutral/Positive sentiment (CAR[-1,1])

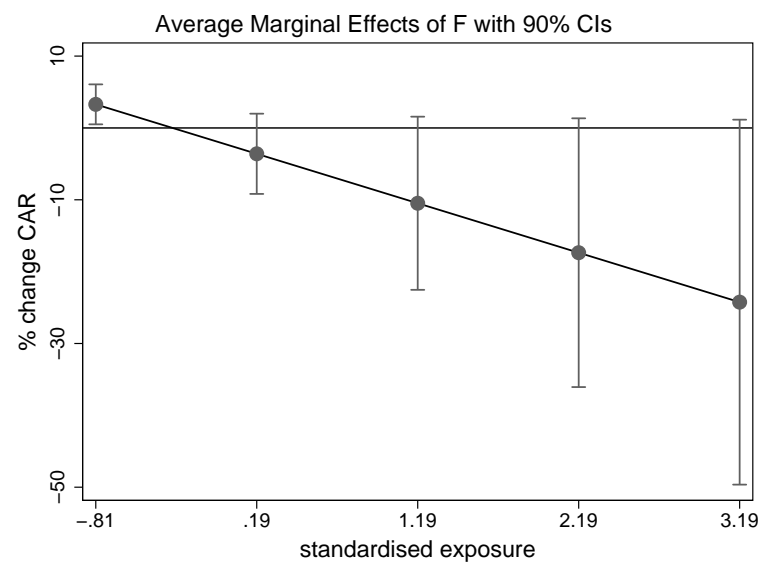

(d) Neutral/Positive sentiment CAR[-10,10]

Figure 2: Marginal effects (\% change in CAR) of a standard deviation increase in fine, plotted against media exposure. Notes: The figures show how the marginal effect of fine on CAR changes for different levels of media exposure and sentiment. The panels on the left are calculated at a negative value of sentiment $\left(5^{\text {th }}\right.$ percentile of the sentiment distribution). The panels on the right are calculated at a neutral/positive value of sentiment $\left(95^{\text {th }}\right.$ percentile of the sentiment distribution). The top panel depicts the effect on the proximity of the decision; the bottom panel depicts the effect around a wider time window.

sanction has an increasingly negative effect if the media coverage is extensive and more positive.

These results would imply that if media coverage is negative, i.e. there is a reputational penalty, then the increase of this penalty (more exposure) reduces the effect of the public sanction. One the other hand, where the sentiment is neutral, and carries no reputational punishment, then the fine steps in and its negative impact grows as the neutral/positive exposure intensifies. These findings suggest that the administrative penalty has 
a more negative effect on the market valuation of the cartel members if there is limited reputational damage, and it loses its effect where there is also reputational penalty. These imply that public and reputational sanctions are substitutes in the case of cartels, confirming the findings of studies like Karpoff and Lott Jr (1993) and Ganuza et al. (2016).

Finally, to further support our findings, we also executed a formal test, following Carree et al. (2011), who offer a simple test for cases, where the researcher seeks to establish the relationship between more than two variables (as is the case in our task). Carree et al. (2011) highlight the weaknesses of using pairwise interaction terms and offers a formal test substitutability and complementarity. We apply their test for our three variables of interest. ${ }^{28}$ We found that there is substitutability between fines and media coverage with negative sentiment in the time windows where sentiment has a significant effect $[-10,10] .{ }^{29}$

\subsection{A regression tree approach}

To dig further into the relationship between the main variables of interest, we employ a regression tree approach. In Figure B.3 in the Appendix we display the regression trees for CAR[-1,1] (a), CAR[-10,10] (b), based on the standardised variables: normalised fine, exposure and sentiment. In each regression tree, the values to the left branches are those where the inequality shown at each node is satisfied. For example, in sub-figure B.3(a) the top node assigns observations having fine $\geq 2.8$ to the left branch. In that node, for very large fines ( $\geq 2.8$, which accounts for $3 \%$ of the observations), the predicted cumulative abnormal rate of return in the proximity of the decision drops by $7.5 \%$. Similarly, if the fine belongs to the interval $[0.25,1.8]$, the predicted value is $-2.4 \%$ (9\% of the observations). Sentiment does play a role too, but only where fine is smaller than 0.25 ( $85 \%$ of our sample). In this case if the sentiment is less negative $(\geq-1.1)$ then the fine plays a role again. On the other hand, if the sentiment is more negative $(<-1.1)$

\footnotetext{
${ }^{28}$ Details of this test are provided in Section A in the Appendix.

${ }^{29}$ To run the test, we have standardised each of the original variables E, F, and S and implemented the transformation suggested by Carree et al. (2011).
} 
then the fine does not seem to play a role any more. This would also seem to support the above finding of substitutability between reputational and public sanctions. Looking at sub-figure B.3(b) we note that sentiment and exposure appear high up on the regression tree, which suggests that sentiment plays a more prominent role in the wider windows around the decision.

Another way of analysing the relationship between our main variables is to look at the importance of each predictor, i.e. how much a feature helped to construct the decision tree. We document in Table B.2 in the Appendix, the importance of fine, exposure and sentiment, and note that fine is the most important factor in determining the cumulative abnormal rate of return in the immediate proximity of the decision. For longer event windows, sentiment and exposure become more important. These results indicate that the public sanction has a dominant role when announced, but otherwise, reputational sanctions are more effective. This would seem to suggest that when the public sanction loses its impact (as we get further away from the announcement of these fines), it is replaced by the reputational sanction, i.e. public and private (reputational sanctions) act as substitutes. The same pattern is confirmed when we add additional predictors in columns (5)-(8), whose regression trees are displayed Figure B.4 in the Appendix. We read the fact that public sanctions are relevant at the decision and that reputational sanctions bite after the decision as sequential complementarity between the two sources of deterrence.

\subsection{Robustness checks}

We conducted a number of sensitivity and robustness checks for various model specifications, sub-samples, and different measures of sentiment. Most importantly, we wanted to experiment with our measure of sentiment. A summary of these results is given in Tables B.3 and B.4. The full tables, together with graphical representations of the marginal effect of our outcome measures are given in the Online Appendix.

First of all, we wanted to see if stronger sentiments (positive or negative) had any effect on abnormal returns. 
This was partly shown in Section 5.2, when comparing the results from using the general and our custom lexicon. The custom lexicon, which reflects a better understanding of the gravity of cartel offences leads to more negative sentiment scores, and as a result we find a stronger effect on abnormal rate of return. To add another step, we squared the sentiment scores, derived using our custom lexicon (and keeping their positive and negative signs), to give more weight to strongly negative and strongly positive sentiment. The idea behind this transformation was to see what would happen if reading about cartel related news triggered more extreme sentiments. Our results in columns (5) and (6) of Table B.3, show that the effect of the reputational sanction is intensified by the transformation. Not only that, but the substitutability between the public and private fines also becomes more pronounced. This has important policy implications. It confirms that competition authorities could improve the deterrence effect of their work if news on cartels were communicated in a way that unambiguously indicates the gravity of such behaviour.

Next, we looked at sources of heterogeneity. To compare if the above findings hold across different industries, we looked at manufacturing and all other industries separately. Manufacturing accounted for more than $2 / 3$ of the sample, and the other industries were each individually too small in our sample. The results, reported in columns (3) and (4) of Table B.3 show that our findings hold when the manufacturing industry is looked at separately.

We then looked at whether re-weighting the articles based on their circulation would significantly change our findings. As explained in Section 4.3, accurate circulation figures (including online and printed) were not available to us. Instead, our weights reflect the geographical coverage of each news, plus more weight for news from English speaking countries. These weights are imperfect: a publication in a developing country with large population might have large dissemination but it is unlikely to be strongly relevant for our research question. Nevertheless, we present the results in columns (7) and (8) of Table B.3. The effect of the fine, exposure and sentiment are similar to the results with the unweighted articles. The interaction 
terms are less significant, but the graphical representation in the Online Appendix shows that our story of substitutability remains.

To check for variation over time, we took the year which gave us an even split of the sample (2005) and looked at whether our findings differed in the pre- and post- samples. The estimates, shown in columns (1)-(4) of Table B.4, suggest that the results described for the full sample are qualitatively the same for both sub-samples, but are more pronounced in the post-2005 sub-sample. This is true for the impact of the fine, but also the impact of media exposure and sentiment. Our interpretation is that the market learns over time, both what it means to be fined by the Commission (end of cartel profit and a pecuniary fine), and what it means to get negative coverage in the press.

We were also interested in how the size of the cartel (number of cartel members) would affect our findings. In columns (5)-(8) of Table B.4 we show that the effect of the public fine is similar for cartels with few and for many members. However, our results suggest that the reputational effect only works for cartels with fewer members. One explanation could be that cartels with fewer members tend to be in more concentrated markets, therefore the media exposure is more discernible for each member.

Finally, we considered whether bid rigging cartels were different from the other cartels, and whether having a ringleader in the cartel had any effect on our findings. As there were not enough bid rigging or ringleader cases to focus only on them, we removed these from our sample and looked at how the results changed. Columns (9) and (10) of Table B.4 show that when bid rigging cases are removed, the effect of the public fine remains, but the reputational effect weakens, suggesting that bid rigging cases contribute more to our findings on the reputation effects. We find similar changes when ringleader cases are removed (columns (11) and (12) of Table B.4). Our interpretation is that ringleaders are more likely, where traditional cartel problems are most acute, e.g. exhibiting substantial size asymmetries (Davies and De, 2013). The large cartel members are then more likely to be covered in media reports, and be associated with increased 
reputational effects.

\section{Conclusions}

From these preliminary results, the message is that, assuming that businesses rationality respond to expected changes in their market valuation, both public and private (market-based, or reputational) sanctions are likely to act as a deterrent to corporate misbehaviour. We found evidence that public fines are effective and their effect can be enhanced over time with reputational sanctions. This would suggest that when administering a pecuniary sanction, policymakers should consider the level and content of media exposure and use of language that lays bare the gravity of the conduct. Media exposure and the disseminated information can be seen as something that can be influenced (controlled) by the regulator - for example if it wants to intensify the effect of reputational sanctions (naming and shaming). By ensuring that the public receives wider and more negative information on the discovered cartel, and by making clear the gravity of corporate misbehaviour, they can increase the reputational penalty. ${ }^{30}$

On the other hand it is also clear that without public sanctions, private sanctions would be much less effective. This is mainly true because of information asymmetry: if there was no cartel conviction, customers of a cartel would not be able to find out if there was collusion - on the other hand wherever there is a public sanction, it receives a sufficient amount of media coverage to reduce the information asymmetry. This is similar to the intuition in Baker and Choi (2013).

This offers important evidence for the debate on the deterrent effect of cartel sanctions. There are increasing voices claiming, that cartel fines may not be sufficient to deter future cartels (Bigoni et al., 2012; Allain et al., 2015; or Smuda, 2013). Moreover, González and Moral (2019) find evidence in the Spanish retail petrol market that cartel fines are followed by increased prices, with potential explanation that penalised

\footnotetext{
${ }^{30}$ Of course, if the regulator were to use the cocktail of reputational and public sanctions on a more regular basis, share prices might anticipate that. This would change the results presented in this work, possibly leading to no effect on high exposure, and larger positive effect for limited exposure - as this will be expected to be more of a rare event.
} 
firms pass on the fine to consumers. there is debate on whether cartel fines are sufficient to deter cartels. In search of improving deterrence, Harrington Jr (2017) argues for the use of structural remedies in cartel cases to corroborate deterrence. Our evidence suggests that reputational effects (something that is likely to hit cartel member where it hurts more, i.e. their future demand) is another potentially key factor to be considered in this debate.

This paper should be seen as a new approach to empirically evaluate the effectiveness of the combination of reputational and public sanctions using sentiment analysis to retrieve information on how customers and consumers are informed about the misconduct. However, there are important aspects that this work was not able to cover, but are worth studying in the future. There would be much to learn from richer information on exposure to the news. Another aspect worth researching is the different use of language for domestic companies and international companies, from which one could study the presence of a bias for domestic companies. A similar distinction can be drawn between industry specialised news, news agencies, and consumer news, as they may use different languages and trigger different sentiments. We attempted to give an answer to these questions but further work would be required for more informative results. Finally, machine learning and natural language processing methods are fast evolving and their development can help improve the quality of the sentiment analysis required for this type of work. 


\section{Appendix}

\section{A Testing substitutability and complementary}

For a general cost function with $n$ variables $f\left(x_{1}, x_{2}, \cdots, x_{n}\right)$, Baumol et al. (1982) suggests that two variables $x_{i}$ and $x_{j}$ are complements (substitutes) if and only if $\frac{\partial^{2} f}{\partial x_{i} \partial x_{j}} \geq 0(\leq 0) \forall\left(x_{1}, x_{2}, \cdots, x_{n}\right)$ - with the inequality being strict for at least one value of the variables. Building on this logic, Carree et al. (2011) show that if the function with three variables is

$$
f\left(x_{i}, x_{j}, x_{k}\right)=\alpha_{i} x_{i}+\alpha_{j} x_{j}+\alpha_{i j} x_{i} x_{j}+\alpha_{k} x_{k}+\alpha_{i k} x_{i} x_{k}+\alpha_{j k} x_{j} x_{k}+\alpha_{i j k} x_{i} x_{j} x_{k},
$$

then there is complementarity (substitutability) between variables $i$ and $j$, if and only if $\alpha_{i j}+\alpha_{i j k} x_{k} \geq 0(\leq$ $0)$, whose sign can be studied at the two extremes $\alpha_{i j}+\alpha_{i j k} \min \left(x_{k}\right) \geq 0(\leq 0)$ and $\alpha_{i j}+\alpha_{i j k} \max \left(x_{k}\right) \geq$ $0(\leq 0)$, with at least one of the two inequalities holding as strict.

Next, if the three variables are normalised to the interval $[0,1]$, then the previous inequalities simplify to $\alpha_{i j} \geq 0(\leq 0)$ and $\alpha_{i j}+\alpha_{i j k} \geq 0(\leq 0)$. A further transformation of $f$, written as econometric equation, with error term $\varepsilon \sim N\left(0, \sigma^{2}\right)$,

$$
y=\alpha_{i} x_{i}+\alpha_{j} x_{j}+\alpha_{k} x_{k}+\alpha_{i k} x_{i} x_{k}+\alpha_{j k} x_{j} x_{k}+\alpha_{i j}\left(x_{i} x_{j}-x_{i} x_{j} x_{k}\right)+\left(\alpha_{i j}+\alpha_{i j k}\right) x_{i} x_{j} x_{k}+\varepsilon,
$$

gives a simple way to test for complementarity and substitutability based on the $t$-value of the coefficients of interest $\alpha_{i j}$ and $\left(\alpha_{i j}+\alpha_{i j k}\right)$. Denoting with $t_{d}$ the one-sided critical value and with $t_{c}$ the two-sided one, then there is complementarity between variables $i$ and $j$ if and only if the $t$-values of the first coefficient of interest, $t_{1}$, and that of the second one, $t_{2}$, satisfy either $\left(t_{1}>t_{c}\right) \&\left(t_{2}>-t_{d}\right)$ or $\left(t_{1}>-t_{d}\right) \&\left(t_{2}>t_{c}\right)$. There is substitutability if either $\left(t_{1}<-t_{c}\right) \&\left(t_{2}<t_{d}\right)$ or $\left(t_{1}<t_{d}\right) \&\left(t_{2}<-t_{c}\right)$. 


\section{B Additional tables and figures}

Table B.1: News articles about the Banana cartel

\begin{tabular}{llcllc}
\hline Cartel & Source & Words & Title & N firms \\
\hline Banana & Daily Mail & 134 & Fyffes is cleared in price-fixing probe & 3 \\
Banana & Edmonton Journal & 237 & Two banana importers skinned by EU for \$82M & 3 \\
Banana & European Report & 413 & Cartels: 60.3 million euro in fines for banana cartel & 3 \\
Banana & Irish Independent & 388 & Fyffes escapes EU fine after major banana price-fixing & 4 \\
Banana & The Toronto Star & 135 & Dole, Del Monte fined for banana price fixing & 4 \\
Banana & Agence France-Presse (English) & 143 & EU squashes banana cartel & 3 \\
Banana & Associated Press Financial Wire & 244 & EU fines banana importers for cartel actions & 3 \\
Banana & Associated Press Financial Wire & 235 & EU fines banana importers for price fixing & 3 \\
Banana & Associated Press Financial Wire & 95 & EU fines banana importers for running cartel & 3 \\
Banana & Business World (Digest) & 198 & Fyffes escapes EU E60m banana fine & 3 \\
Banana & Just-food Global News & 187 & EU: Commission fines banana cartel & 3 \\
Banana & RTE News & 380 & Fyffes escapes EU banana fine & 3 \\
Banana & Associated Press International & 106 & EU fines banana importers for running cartel & 3 \\
Banana & Associated Press International & 237 & EU fines banana importers for cartel actions & 3 \\
Banana & Associated Press Online & 237 & EU fines banana importers for price fixing & 3 \\
\hline
\end{tabular}

Notes: This table lists and summarises the news about the Banana cartel. The last column records the number of firms mentioned in the news.

Table B.2: Feature importance in percentage

\begin{tabular}{lrrrr}
\hline & CAR[-1,1] & CAR[-10,10] & CAR[-1,1] & CAR[-10,10] \\
\hline & $(1)$ & $(2)$ & $(3)$ & $(4)$ \\
stdised exposure (E) & 15 & 13 & 5 & 6 \\
stdised fine (F) & 72 & 66 & 55 & 32 \\
stdised sentiment (S) & 13 & 21 & 1 & 11 \\
size & & & 4 & 7 \\
duration & & 1 & 5 \\
dummy duration & & 4 & 3 \\
dummy leniency & & 0 & 3 \\
dummy recidivist & & 8 & 1 \\
time trend & & 14 & 21 \\
mk capitalis. & & & 7 \\
\hline
\end{tabular}

Notes: This table shows-for two different time windows of CAR-the feature of importance (in percentage) of the variables included in the regression tree analysis. 
Table B.3: Regression analysis of percentage CAR (robustness checks)

\begin{tabular}{|c|c|c|c|c|c|c|c|c|c|c|}
\hline & \multicolumn{2}{|c|}{ sentim general } & \multicolumn{2}{|c|}{ manufact industry } & \multicolumn{2}{|c|}{ sentim custom square } & \multicolumn{2}{|c|}{ wght sentim custom } & \multicolumn{2}{|c|}{ sentim custom cartel FE } \\
\hline & $\begin{array}{l}\text { CAR }[-1,1] \\
\text { (1) }\end{array}$ & $\begin{array}{l}\text { CAR }[-10,10] \\
\text { (2) }\end{array}$ & $\begin{array}{l}\text { CAR }[-1,1] \\
\text { (3) }\end{array}$ & $\begin{array}{l}\text { CAR[-10,10] } \\
\text { (4) }\end{array}$ & $\begin{array}{l}\text { CAR }[-1,1] \\
\text { (5) }\end{array}$ & $\begin{array}{l}\text { CAR[-10,10] } \\
\text { (6) }\end{array}$ & $\begin{array}{l}\text { CAR }[-1,1] \\
\text { (7) }\end{array}$ & $\begin{array}{l}\text { CAR[-10,10] } \\
(8)\end{array}$ & $\begin{array}{l}\text { CAR }[-1,1] \\
\text { (9) }\end{array}$ & $\begin{array}{l}\text { CAR }[-10,10] \\
\text { (10) }\end{array}$ \\
\hline \multicolumn{11}{|c|}{ linear regression } \\
\hline cons & $\begin{array}{l}-0.595^{b} \\
(0.230)\end{array}$ & $\begin{array}{l}-2.072^{a} \\
(0.678)\end{array}$ & $\begin{array}{l}-0.459^{c} \\
(0.262)\end{array}$ & $\begin{array}{l}-2.490^{a} \\
(0.745)\end{array}$ & $\begin{array}{l}-0.595^{b} \\
(0.229)\end{array}$ & $\begin{array}{l}-2.072^{a} \\
(0.662)\end{array}$ & $\begin{array}{l}-0.595^{b} \\
(0.229)\end{array}$ & $\begin{array}{l}-2.072^{a} \\
(0.661)\end{array}$ & $\begin{array}{l}-0.595^{b} \\
(0.240)\end{array}$ & $\begin{array}{l}-2.072^{a} \\
(0.671)\end{array}$ \\
\hline E & -0.214 & 0.426 & -0.118 & $\begin{array}{l}1.393^{b} \\
(0.684)\end{array}$ & -0.167 & $\begin{array}{l}0.956^{c} \\
(0.504)\end{array}$ & $\begin{array}{l}-0.172 \\
(0209)\end{array}$ & $1.078^{b}$ & $\begin{array}{l}-0.455 \\
(0.626)\end{array}$ & 0.077 \\
\hline $\mathrm{F}$ & $\begin{array}{c}-1.037^{a} \\
(0.332)\end{array}$ & $\begin{array}{l}-0.966 \\
(0.877)\end{array}$ & $\begin{array}{c}-1.081^{a} \\
(0.366)\end{array}$ & $\begin{array}{c}-0.834 \\
(0.937)\end{array}$ & $\begin{array}{l}-1.038^{a} \\
(0.334)\end{array}$ & $\begin{array}{l}-1.007 \\
(0.837)\end{array}$ & $\begin{array}{c}-1.038^{a} \\
(0.332)\end{array}$ & $\begin{array}{c}-0.986 \\
(0.845)\end{array}$ & $\begin{array}{c}-1.157^{a} \\
(0.395)\end{array}$ & $\begin{array}{l}-1.594 \\
(0.979)\end{array}$ \\
\hline$S$ & $\begin{array}{l}0.062 \\
(0.225)\end{array}$ & $\begin{array}{l}1.102 \\
(0.696)\end{array}$ & $\begin{array}{l}0.302 \\
(0.312)\end{array}$ & $\begin{array}{l}2.541^{b} \\
(1.036)\end{array}$ & $\begin{array}{l}0.188 \\
(0.241)\end{array}$ & $\begin{array}{l}2.366^{a} \\
(0.817)\end{array}$ & $\begin{array}{l}0.154 \\
(0.248)\end{array}$ & $\begin{array}{l}2.462^{a} \\
(0.830)\end{array}$ & $\begin{array}{l}0.326 \\
(0.570)\end{array}$ & $\begin{array}{l}0.871 \\
(1.812)\end{array}$ \\
\hline Joint $F$ & $3.671^{b}$ & 1.635 & $3.380^{b}$ & $3.724^{b}$ & $3.789^{b}$ & $3.798^{b}$ & $3.742^{b}$ & $3.947^{a}$ & $3.179^{b}$ & 1.030 \\
\hline & 0.067 & 0.021 & 0.091 & 0.058 & 0.069 & 0.056 & 0.068 & 0.058 & 0.242 & 0.335 \\
\hline \multicolumn{11}{|c|}{ linear regression with interactions } \\
\hline cons & $\begin{array}{c}-0.586^{b} \\
(0.235)\end{array}$ & $\begin{array}{c}-2.491^{a} \\
(0.713)\end{array}$ & $\begin{array}{l}-0.543^{c} \\
(0.287)\end{array}$ & $\begin{array}{l}-3.141^{a} \\
(0.797)\end{array}$ & $\begin{array}{c}-0.580^{b} \\
(0.243)\end{array}$ & $\begin{array}{l}-2.542^{a} \\
(0.690)\end{array}$ & $\begin{array}{l}-0.525^{b} \\
(0.249)\end{array}$ & $\begin{array}{c}-2.452^{a} \\
(0.686)\end{array}$ & $\begin{array}{l}-0.720 \\
(0.496)\end{array}$ & $\begin{array}{l}-2.288^{b} \\
(1.157)\end{array}$ \\
\hline $\mathrm{E}$ & -0.235 & -0.503 & -0.242 & 0.863 & -0.200 & 0.157 & -0.105 & 0.282 & -0.637 & -0.020 \\
\hline & $(0.246)$ & $(0.598)$ & $(0.326)$ & $(0.760)$ & $(0.247)$ & $(0.582)$ & $(0.273)$ & $(0.630)$ & $(0.847)$ & $(2.118)$ \\
\hline $\mathrm{F}$ & $\begin{array}{c}-1.059^{a} \\
(0.349)\end{array}$ & $\begin{array}{l}-1.389^{c} \\
(0.735)\end{array}$ & $\begin{array}{c}-1.265^{a} \\
(0.350)\end{array}$ & $\begin{array}{l}-1.523 \\
(0.955)\end{array}$ & $\begin{array}{l}-1.158^{a} \\
(0.354)\end{array}$ & $\begin{array}{l}-1.833^{b} \\
(0.837)\end{array}$ & $\begin{array}{l}-1.001^{b} \\
(0.396)\end{array}$ & $\begin{array}{c}-1.439^{c} \\
(0.768)\end{array}$ & $\begin{array}{l}-1.521^{a} \\
(0.382)\end{array}$ & $\begin{array}{l}-2.704^{a} \\
(0.987)\end{array}$ \\
\hline$S$ & $\begin{array}{l}0.058 \\
(0.225)\end{array}$ & $\begin{array}{l}0.783 \\
(0.679)\end{array}$ & $\begin{array}{l}0.179 \\
(0.337)\end{array}$ & $\begin{array}{l}1.472 \\
(1.009)\end{array}$ & $\begin{array}{l}0.220 \\
(0.242)\end{array}$ & $\begin{array}{l}2.061^{a} \\
(0.731)\end{array}$ & $\begin{array}{l}0.249 \\
(0.261)\end{array}$ & $\begin{array}{l}2.093^{b} \\
(0.819)\end{array}$ & $\begin{array}{l}0.084 \\
(1.077)\end{array}$ & $\begin{array}{l}0.566 \\
(3.069)\end{array}$ \\
\hline EF & $\begin{array}{c}-0.067 \\
(0.588)\end{array}$ & $\begin{array}{l}-2.331^{c} \\
(1.303)\end{array}$ & $\begin{array}{l}-0.266 \\
(0.684)\end{array}$ & $\begin{array}{l}-1.938 \\
(1.606)\end{array}$ & $\begin{array}{l}-0.134 \\
(0.528)\end{array}$ & $\begin{array}{l}-1.424 \\
(1.215)\end{array}$ & $\begin{array}{l}0.247 \\
(0.625)\end{array}$ & $\begin{array}{l}-1.163 \\
(1.225)\end{array}$ & $\begin{array}{l}-0.476 \\
(0.602)\end{array}$ & $\begin{array}{l}-2.190 \\
(1.637)\end{array}$ \\
\hline ES & $\begin{array}{l}0.059 \\
(0.225)\end{array}$ & $\begin{array}{l}-1.671^{a} \\
(0.574)\end{array}$ & $\begin{array}{l}-0.267 \\
(0.391)\end{array}$ & $\begin{array}{l}-2.395^{b} \\
(1089)\end{array}$ & 0.057 & $\begin{array}{c}-1.393^{b} \\
(0.564)\end{array}$ & $\begin{array}{l}0.130 \\
(0.242)\end{array}$ & $\begin{array}{c}-1.239^{c} \\
(0.651)\end{array}$ & -0.373 & $\begin{array}{l}-0.580 \\
(3627)\end{array}$ \\
\hline FS & $\begin{array}{c}-0.090 \\
(0.314)\end{array}$ & $\begin{array}{c}-1.460^{c} \\
(0.797)\end{array}$ & $\begin{array}{l}-0.225 \\
(0.404)\end{array}$ & $\begin{array}{c}-0.406 \\
(1.194)\end{array}$ & $\begin{array}{l}-0.039 \\
(0.371)\end{array}$ & $\begin{array}{c}-0.129 \\
(0.874)\end{array}$ & $\begin{array}{l}0.517 \\
(0.494)\end{array}$ & $\begin{array}{l}0.084 \\
(1.127)\end{array}$ & $\begin{array}{l}-0.598 \\
(0.506)\end{array}$ & $\begin{array}{l}-1.584 \\
(1.274)\end{array}$ \\
\hline EFS & $\begin{array}{l}-0.224 \\
(0.391)\end{array}$ & $\begin{array}{l}-3.075^{a} \\
(1.109)\end{array}$ & $\begin{array}{l}-0.866^{c} \\
(0.442)\end{array}$ & $\begin{array}{l}-2.850 \\
(1.764)\end{array}$ & $\begin{array}{l}-0.476 \\
(0.352)\end{array}$ & $\begin{array}{l}-2.930^{a} \\
(1.111)\end{array}$ & $\begin{array}{l}-0.062 \\
(0.461)\end{array}$ & $\begin{array}{l}-2.444 \\
(1.577)\end{array}$ & $\begin{array}{l}-1.219^{a} \\
(0.467)\end{array}$ & $\begin{array}{l}-3.560^{b} \\
(1.488)\end{array}$ \\
\hline Joint $F$ & 1.722 & $2.487^{b}$ & $2.337^{b}$ & $3.357^{a}$ & $2.162^{b}$ & $4.170^{a}$ & $1.857^{c}$ & $4.218^{a}$ & $2.691^{b}$ & 1.575 \\
\hline $\mathrm{R}^{2}$ & 0.068 & 0.062 & 0.103 & 0.096 & 0.074 & 0.092 & 0.077 & 0.080 & 0.254 & 0.350 \\
\hline Obs & 287 & 287 & 206 & 206 & 287 & 287 & 148 & 148 & 287 & 287 \\
\hline
\end{tabular}

days. The first two columns employ the general measure of sentiment score, all other columns use the custom sentiment score; columns (3) and (4) restrict the empirical analysis to the manufacturing industry; columns (5) and (6) use employ the square of the custom sentiment score (preserving the original negative signs); columns (7) and (8) weight the custom sentiment score by the readership of the news; finally columns (9) and (10) use custom sentiment score but controls for cartel dummy variables. Significance level: ${ }^{a} p<0.01,{ }^{b} p<0.05,{ }^{c} p<0.10$. Clustered (by firm) standard error in parenthesis. $*$ Controls: number of cartel members, cartel duration, dummy for observations with no data on cartel duration, dummy for recidivist firm, dummy indicating whether the firm received

leniency, time trend, and firm market capitalisation (proxy for firm size).

\section{Table B.4: Regression analysis of percentage CAR (robustness checks)}

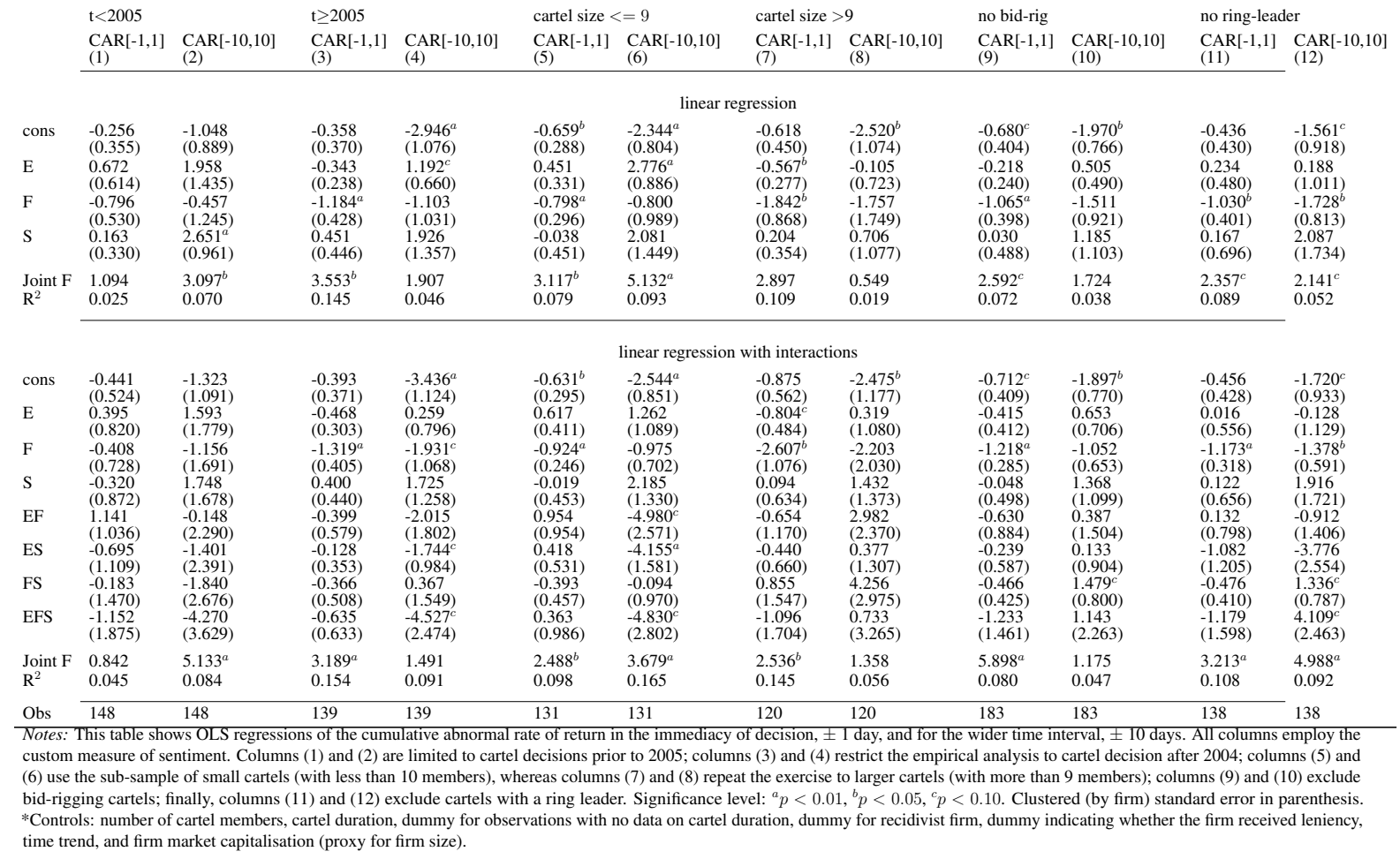


Table B.5: Cartel characteristics

\begin{tabular}{|c|c|c|c|c|c|c|c|c|c|c|c|}
\hline Cartel & size & year bust & $\begin{array}{c}\text { year } \\
\text { detection }\end{array}$ & $\begin{array}{l}\text { year con- } \\
\text { viction }\end{array}$ & $\begin{array}{l}\text { duration } \\
\text { (in years) }\end{array}$ & $\begin{array}{l}\text { ring } \\
\text { leader }\end{array}$ & $\begin{array}{l}\text { market } \\
\text { cover- } \\
\text { age }\end{array}$ & quota & $\begin{array}{c}\text { market } \\
\text { share } \\
\text { alloca- } \\
\text { tion }\end{array}$ & $\begin{array}{l}\text { price } \\
\text { fixing }\end{array}$ & $\begin{array}{l}\text { bid rig- } \\
\text { ging }\end{array}$ \\
\hline $\begin{array}{l}\text { UK Agric tractors } \\
\text { Shipowners } \\
\text { Quantel Internat }\end{array}$ & & & & & & & & & & & \\
\hline Chemin de fer & & & & & & & & & & & \\
\hline Cewal, Cowac and Ukwal & 3 & 2003 & 1991 & 1992 & 2 & & 0.81 & 1 & 1 & 0 & 0 \\
\hline Steel Beams & 18 & 1991 & 1991 & 1994 & 3 & 0 & & 1 & 1 & 1 & 0 \\
\hline Cartonboard & 19 & 1991 & 1991 & 1994 & 3 & 0 & & 1 & 1 & 1 & 0 \\
\hline PVC & 12 & 1984 & 1983 & 1994 & 3 & 0 & & 1 & 1 & 1 & 0 \\
\hline $\begin{array}{l}\text { Cement } \\
\text { Freight confer }\end{array}$ & 76 & 1992 & 1990 & 1994 & 9 & 1 & & 0 & 1 & 1 & 0 \\
\hline $\begin{array}{l}\text { Fenex } \\
\text { Ferry operators }\end{array}$ & 4 & 1991 & 1991 & 1996 & 4 & 1 & 0.11 & 0 & 0 & 1 & 0 \\
\hline $\begin{array}{l}\text { Extra d'alliage } \\
\text { TACA }\end{array}$ & 6 & 1995 & 1995 & 1998 & 4 & 0 & 0.92 & 0 & 0 & 1 & 0 \\
\hline British sugar & 4 & 1990 & 1990 & 1998 & 4 & 1 & 0.92 & 0 & 0 & 1 & 0 \\
\hline Gas switchgear & 11 & 2004 & 2004 & 2007 & 16 & 1 & 1.00 & 1 & 1 & 1 & 1 \\
\hline $\begin{array}{l}\text { Greek ferries } \\
\text { FEG \& TU }\end{array}$ & 7 & 1992 & 1992 & 1998 & 7 & 1 & 1.00 & 0 & 0 & 1 & 0 \\
\hline Steel tubes & 8 & 1994 & 1994 & 1999 & 5 & 0 & 1.00 & 0 & 1 & 0 & 1 \\
\hline FETTSCA & 15 & 1992 & 1992 & 2000 & 23 & 0 & 0.73 & 1 & 1 & 1 & 0 \\
\hline Amino acids & 5 & 1995 & 1995 & 2000 & 5 & 1 & 1.00 & 1 & 1 & 1 & 0 \\
\hline Carb de soude Solvay-CFK & & & & & & & & & & & \\
\hline SAS + Maersk Air & 2 & 1998 & 1994 & 2001 & 2 & 1 & 1.00 & 0 & 1 & 0 & 0 \\
\hline $\begin{array}{l}\text { Graphite electrodes } \\
\text { Commissions bancaires }\end{array}$ & 8 & 1997 & 1997 & 2001 & 6 & 1 & 0.85 & 1 & 1 & 1 & 0 \\
\hline $\begin{array}{l}\text { Vitamins } \\
\text { Interbrew + Alken Maes }\end{array}$ & 13 & 1994 & 1998 & 2001 & 9 & 1 & 0.91 & 1 & 1 & 1 & 0 \\
\hline Luxembourg brewing & 4 & 2000 & 2000 & 2001 & 15 & 0 & 0.85 & 0 & 1 & 0 & 0 \\
\hline Citric acid & 5 & 1998 & 1995 & 2001 & 4 & 1 & 0.60 & 1 & 1 & 1 & 1 \\
\hline Zinc phosphate & 6 & 1998 & 1998 & 2001 & 4 & 0 & 0.98 & 1 & 1 & 1 & 0 \\
\hline Commissions bancaires D & 5 & 1999 & 1999 & 2001 & 4 & 0 & 0.39 & 0 & 0 & 1 & 0 \\
\hline Carbonless paper & 11 & 1995 & 1996 & 2001 & 4 & 1 & 0.90 & 1 & 1 & 1 & 0 \\
\hline AU Banken & 8 & 1998 & 1998 & 2002 & 4 & 0 & 1.00 & 0 & 0 & 1 & 0 \\
\hline Methionine & 3 & 1999 & 1999 & 2002 & 13 & 0 & 0.60 & 1 & 1 & 1 & 0 \\
\hline Medical gases & 7 & 1997 & 1997 & 2002 & 4 & 0 & 0.87 & 0 & 0 & 1 & 0 \\
\hline Fine art auctions & 2 & 2000 & 1997 & 2002 & 7 & 0 & 0.90 & 0 & 0 & 1 & 0 \\
\hline Methylglucamine & 2 & 1999 & 1998 & 2002 & 9 & 0 & 1.00 & 0 & 1 & 1 & 0 \\
\hline $\begin{array}{l}\text { Plasterboard } \\
\text { lat }\end{array}$ & 4 & 1998 & 1998 & 2002 & 7 & 0 & 0.99 & 1 & 1 & 1 & 0 \\
\hline Graphite & 8 & 1996 & 1999 & 2002 & 5 & 1 & 0.80 & 0 & 1 & 1 & 0 \\
\hline Food flavour & 4 & 1998 & 1995 & 2002 & 10 & 0 & 0.90 & 0 & 1 & 1 & 0 \\
\hline Ronds à béton & & & & & & & & & & & \\
\hline $\begin{array}{l}\text { Sodium gluconate } \\
\text { Viandes Bovines }\end{array}$ & 5 & 1995 & 1997 & 2002 & 8 & 1 & 1.00 & 1 & 1 & 1 & 0 \\
\hline $\begin{array}{l}\text { Viandes Bovines } \\
\text { Sorbates }\end{array}$ & 5 & 1996 & 1998 & 2003 & 18 & 1 & 1.00 & 1 & 1 & 1 & 0 \\
\hline Carbon and graphite & 6 & 1999 & 2001 & 2003 & $\begin{array}{l}10 \\
11\end{array}$ & 0 & 0.93 & 0 & 1 & 1 & 1 \\
\hline Organic peroxyde & 5 & 1999 & 2000 & 2003 & 29 & 0 & 0.93 & 1 & 1 & 1 & 0 \\
\hline Tubes industriels & 6 & 2001 & 2001 & 2003 & 13 & 0 & & 0 & 1 & 1 & 0 \\
\hline CEWAL, MEWAC ... & & 1989 & 1989 & 2004 & 2 & & 0.90 & 0 & 1 & 0 & 0 \\
\hline Copper tubes & 8 & 2001 & 2001 & 2004 & 13 & 0 & 0.79 & 0 & 1 & 1 & 0 \\
\hline FR beer & 2 & 1996 & 1999 & 2004 & 0 & 0 & 0.75 & 1 & 1 & 0 & 0 \\
\hline Raw Tobacco (ES) & 4 & 2001 & 2001 & 2004 & 5 & 1 & 0.98 & 0 & 0 & 1 & 0 \\
\hline Needles & 3 & 1999 & 2000 & 2004 & 5 & 1 & 0.95 & 0 & 1 & 0 & 0 \\
\hline Choline chloride & 3 & 1998 & 1998 & 2004 & 6 & 0 & 0.76 & 1 & 1 & 1 & 0 \\
\hline MCAA & 4 & 1999 & 1999 & 2005 & 15 & 0 & 0.96 & 1 & 1 & 1 & 0 \\
\hline Thread & 10 & 1996 & 2000 & 2005 & 12 & 1 & 0.87 & 0 & 1 & 1 & 1 \\
\hline EMC & & & & & & & & & & & \\
\hline Raw Tobacco IT & 4 & 2002 & 2002 & 2005 & 6 & 0 & 0.56 & 0 & 1 & 1 & 1 \\
\hline Industrial bags & 16 & 2001 & 2001 & 2005 & 21 & 0 & 0.75 & 0 & 1 & 1 & 1 \\
\hline Rubber chemicals & 4 & 2002 & 2002 & 2005 & 6 & 0 & 0.58 & 1 & 1 & 1 & 0 \\
\hline Perborate & 9 & 2000 & 2000 & 2006 & 7 & 0 & 0.96 & 0 & 1 & 1 & 0 \\
\hline Methacrylates & 5 & 2002 & 2002 & 2006 & 6 & 1 & 0.87 & 0 & 0 & 1 & 0 \\
\hline Bitumen NL & 14 & 2002 & 2002 & 2006 & 8 & 1 & 1.00 & 0 & 0 & 1 & 1 \\
\hline Fittings & 11 & 2001 & 2001 & 2006 & 15 & 0 & 0.95 & 0 & 1 & 1 & 1 \\
\hline Butadiene Rubber & 6 & 2002 & 2003 & 2006 & 7 & & & 0 & 1 & 1 & 0 \\
\hline Alloy surcharge & & 1994 & 1997 & 2006 & 1 & & & 0 & 0 & 1 & 0 \\
\hline Elevators & 5 & 2004 & 2004 & 2007 & 9 & 0 & 0.86 & 1 & 1 & 0 & 1 \\
\hline NL beer & 4 & 1999 & 1999 & 2007 & 4 & 0 & 0.90 & 0 & 1 & 1 & 0 \\
\hline Fasteners & 6 & 1999 & 2001 & 2007 & 10 & 0 & 0.97 & 0 & 1 & 0 & 0 \\
\hline Bitumen ES & 5 & 2002 & 2002 & 2007 & 12 & 1 & 0.91 & 1 & 1 & 1 & 1 \\
\hline Videotape & 3 & 2002 & 2002 & 2007 & 3 & 0 & 0.89 & 0 & 0 & 1 & 1 \\
\hline Flat glass & 4 & 2005 & 2005 & 2007 & 1 & 0 & 0.80 & 0 & 0 & 1 & 0 \\
\hline Chloroprene Rubber & 6 & 2000 & 2002 & 2007 & 9 & 0 & 0.89 & 1 & 1 & 1 & 0 \\
\hline Nitrile Rubber & 2 & 2000 & 2002 & 2008 & 9 & 0 & 0.89 & 1 & 1 & 1 & 0 \\
\hline Removal services & 11 & 2003 & 2003 & 2008 & 19 & 0 & 0.50 & 0 & 1 & 0 & 1 \\
\hline Deep-sea transport & & & & & & & & & & & \\
\hline Sodium chlorate & 5 & 2000 & 2003 & 2008 & 5 & 0 & 0.93 & 1 & 1 & 1 & 0 \\
\hline Aluminium fluoride & 5 & 2000 & 2005 & 2008 & 1 & 0 & & 1 & 1 & 1 & 0 \\
\hline $\begin{array}{l}\text { Candle waxes } \\
\end{array}$ & 10 & 2005 & 2005 & 2008 & 13 & 1 & 0.75 & 0 & 1 & 1 & 0 \\
\hline Bananas & 3 & 2002 & 2005 & 2008 & 3 & 0 & 0.43 & 0 & 0 & 1 & 0 \\
\hline Carglass & 4 & 2003 & 2005 & 2008 & 5 & 1 & 0.93 & 0 & 1 & 0 & 1 \\
\hline Marine hoses & 6 & 2007 & 2007 & 2009 & 21 & 1 & 0.92 & 1 & 1 & 1 & 1 \\
\hline Printers (EFIM complaint) & & & & & & & & & & & \\
\hline E.On - GdF & 3 & 2005 & 2006 & 2009 & 26 & & 1.00 & 0 & 1 & 0 & 0 \\
\hline Carbide and magnesium & 8 & 2007 & 2007 & 2009 & 3 & 0 & 0.80 & 0 & 1 & 1 & 0 \\
\hline Power transformers & 7 & 2003 & 2004 & 2009 & 4 & 0 & & 0 & 1 & 0 & 0 \\
\hline Heat stabilisers & 11 & 2000 & 1999 & 2009 & 13 & 0 & 0.90 & 1 & 1 & 1 & 0 \\
\hline DRAMS & 10 & 2002 & 2002 & 2010 & 4 & 0 & 0.93 & 1 & 0 & 1 & 0 \\
\hline Bathroom fittings & 17 & 2004 & 2004 & 2010 & 12 & & & 0 & 0 & 1 & 0 \\
\hline Pre-stressing steel & 17 & 2002 & 2002 & 2010 & 18 & 0 & 0.84 & 1 & 1 & 1 & 1 \\
\hline Animal phosphates & 6 & 2003 & 2003 & 2010 & 35 & 0 & 0.69 & 1 & 1 & 1 & 0 \\
\hline Airfreight & 14 & 2006 & 2006 & 2010 & 6 & & 0.22 & 0 & 0 & 1 & 0 \\
\hline LCD & 6 & 2006 & 2006 & 2010 & 4 & 0 & 0.82 & 0 & 0 & 1 & 0 \\
\hline Consumer detergents & 3 & 2005 & 2008 & 2011 & 2 & & & 0 & 0 & 1 & 0 \\
\hline Exotic fruit & 2 & 2005 & 2005 & 2011 & 1 & 0 & 0.50 & 0 & 0 & 1 & 0 \\
\hline CRT glass bulbs & 4 & 2004 & 2009 & 2011 & 4 & 0 & & 0 & 0 & 1 & 0 \\
\hline
\end{tabular}




\begin{tabular}{|c|c|c|c|c|c|c|c|c|c|c|c|c|}
\hline Refriger compressors & 5 & 2007 & 2009 & 2011 & 4 & 0 & & 0 & 1 & 1 & 0 & $\mathrm{C} 28$ \\
\hline Freight forwarding & 15 & 2007 & 2007 & 2012 & 4 & & & 0 & 0 & 1 & 0 & H53 \\
\hline Mountings windows & 9 & 2007 & 2007 & 2012 & 7 & & & 0 & 0 & 1 & 0 & $\mathrm{C} 25$ \\
\hline Water management & 3 & 2008 & 2008 & 2012 & 2 & & & 0 & 0 & 1 & 0 & $\mathrm{C} 25$ \\
\hline $\mathrm{TV}$ and $\mathrm{PC}$ tubes & 8 & 2006 & 2007 & 2012 & 9 & & & 0 & 1 & 1 & 0 & $\mathrm{C} 26$ \\
\hline BR/ESBR recidivism & & & 2003 & & & & & & & & & \\
\hline Automotive wire & 5 & 2009 & 2010 & 2013 & 9 & 1 & & 1 & 0 & 1 & 0 & $\mathrm{C} 29$ \\
\hline Shrimps & 4 & 2009 & 2009 & 2013 & 9 & 0 & 0.85 & 0 & 1 & 1 & 0 & G46 \\
\hline Euro rate derivatives & 8 & 2008 & 2011 & 2013 & 3 & 0 & & 0 & 0 & 1 & 0 & K64 \\
\hline Yen rate derivatives & 6 & 2010 & 2010 & 2013 & 4 & 0 & & 0 & 0 & 1 & 0 & K64 \\
\hline Polyurethane foam & 4 & 2010 & 2010 & 2014 & 5 & 0 & & 0 & 0 & 1 & 0 & $\mathrm{C} 31$ \\
\hline Power exchanges & 2 & 2012 & 2012 & 2014 & 1 & 0 & & 0 & 1 & 0 & 0 & D35 \\
\hline Automotive bearings & 6 & 2011 & 2011 & 2014 & 7 & 0 & & 1 & 0 & 1 & 0 & $\mathrm{C} 28$ \\
\hline Steel abrasives & 4 & 2010 & 2010 & 2014 & 7 & 0 & & 1 & 0 & 1 & 0 & $\mathrm{C} 23$ \\
\hline Power cables & 26 & 2009 & 2006 & 2014 & 10 & 0 & & 0 & 1 & 0 & 0 & $\mathrm{C} 27$ \\
\hline Mushrooms & 3 & 2012 & 2012 & 2014 & 2 & 0 & & 0 & 1 & 1 & 0 & $\mathrm{C} 10$ \\
\hline Smart card chips & 4 & 2005 & 2008 & 2014 & 2 & 0 & & 0 & 1 & 1 & 0 & $\mathrm{C} 26$ \\
\hline Swiss Franc rate deriv & 4 & 2007 & 2011 & 2014 & 0 & 0 & & 0 & 0 & 1 & 0 & K66 \\
\hline Envelopes & 5 & 2008 & 2010 & 2014 & 5 & 0 & & 0 & 1 & 1 & 1 & $\mathrm{C} 17$ \\
\hline Parking heaters & 2 & 2011 & 2013 & 2015 & 10 & 0 & & 0 & 1 & 1 & 0 & $\mathrm{C} 29$ \\
\hline Food packaging & 10 & 2008 & 2008 & 2015 & 8 & 0 & & 0 & 1 & 1 & 1 & $\mathrm{C} 22$ \\
\hline Car battery & 5 & & 2012 & 2015 & 3 & 0 & & 0 & 0 & 1 & 0 & E38 \\
\hline Blocktrains & 3 & 2012 & 2013 & 2015 & 8 & 0 & & 0 & 1 & 1 & 0 & H49 \\
\hline Cement related products & & & 2008 & 2015 & & & & & & & & $\mathrm{C} 23$ \\
\hline Optical disc drives & 8 & 2008 & 2009 & 2015 & 5 & 0 & & 0 & 0 & 0 & 1 & $\mathrm{C} 26$ \\
\hline Gas switchgear & 2 & 2007 & 2012 & 2012 & 16 & 0 & & 0 & 1 & 0 & 0 & $\mathrm{C} 27$ \\
\hline
\end{tabular}

Table B.6: Firm charactristics and comparison with Aguzzoni et al (2013)

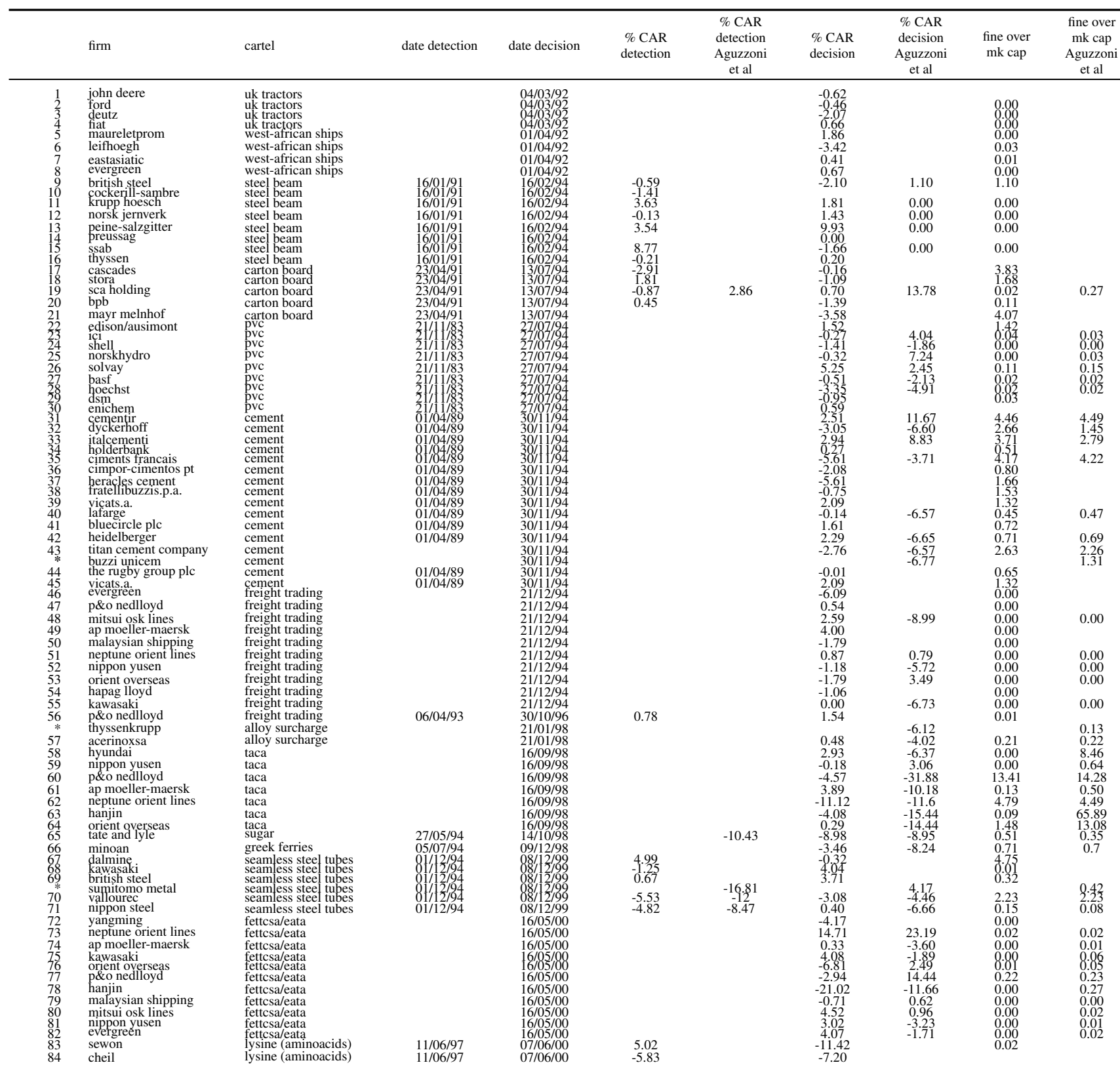




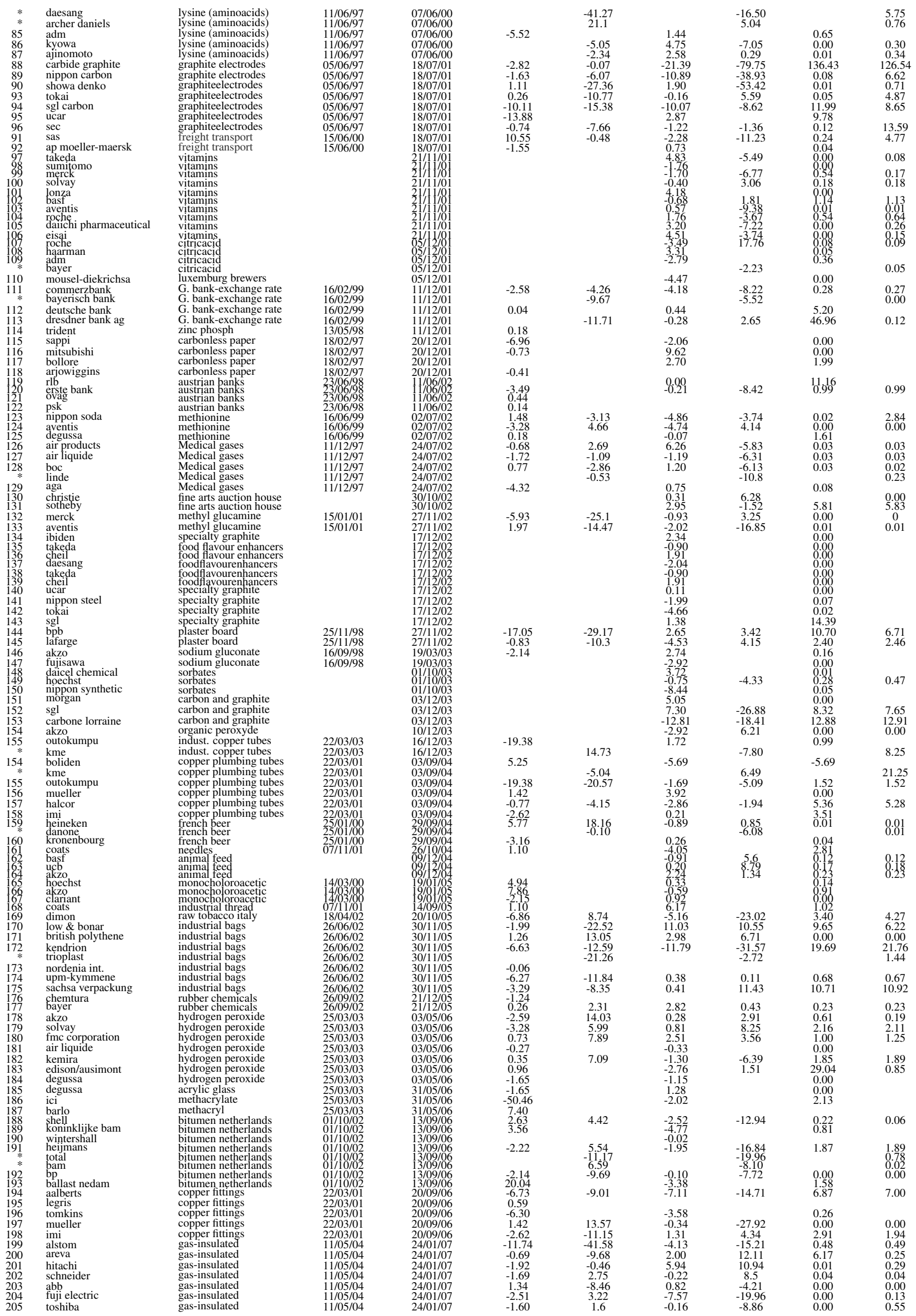




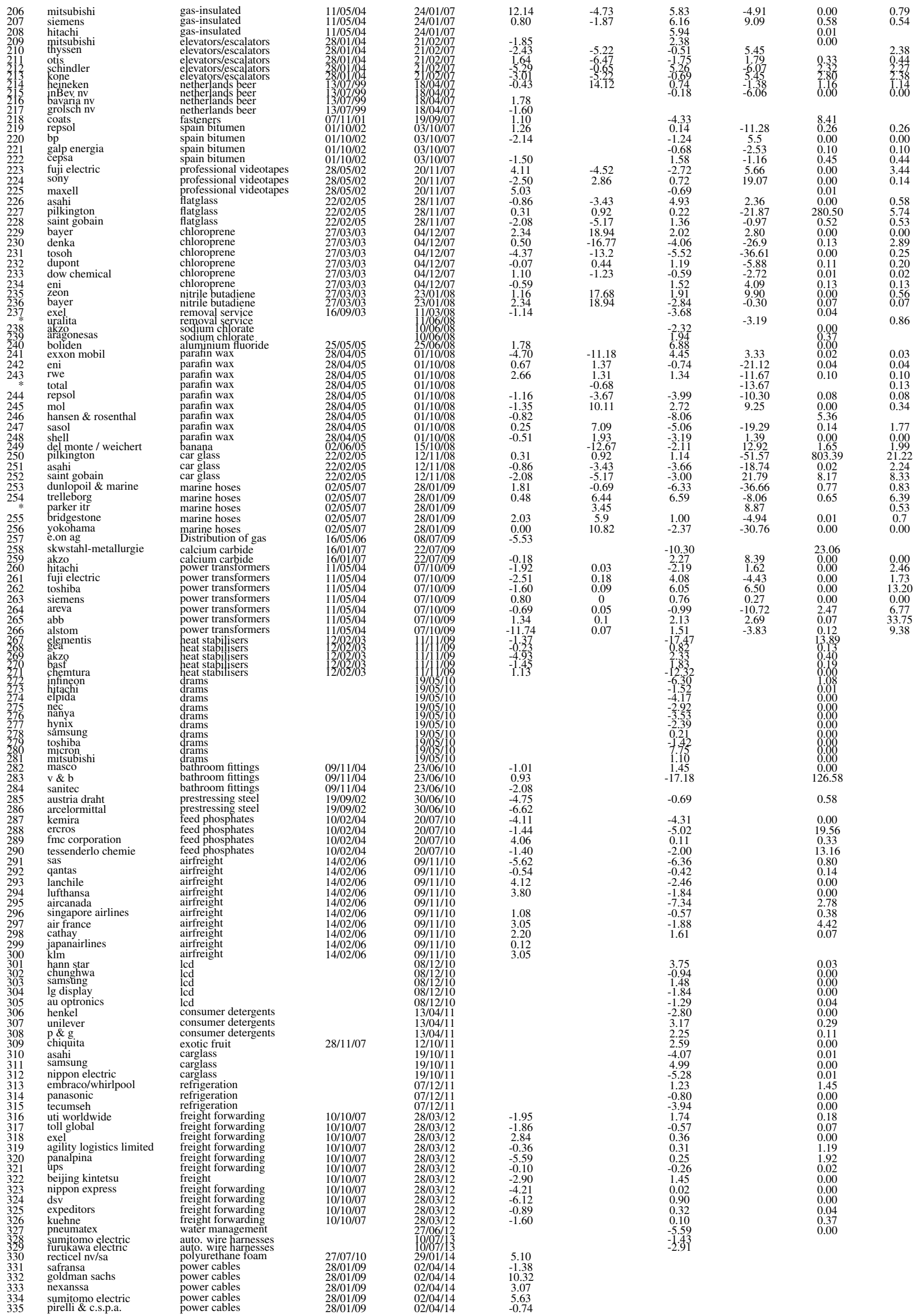




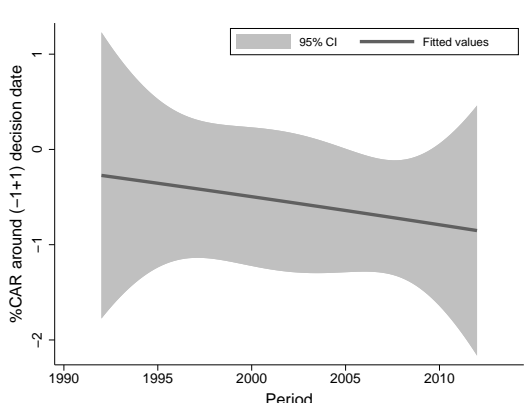

(a) $\mathrm{CAR} \pm 1$ day,

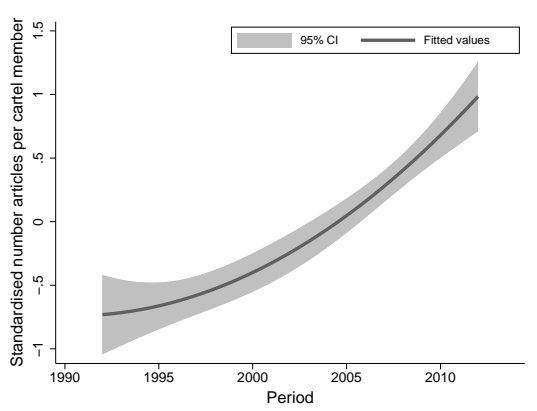

(c) Stdised news articles

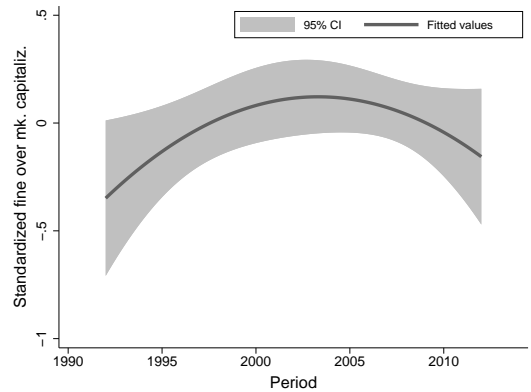

(b) Stdised $\frac{\text { Fine }}{\text { Mk capitaliz }}$

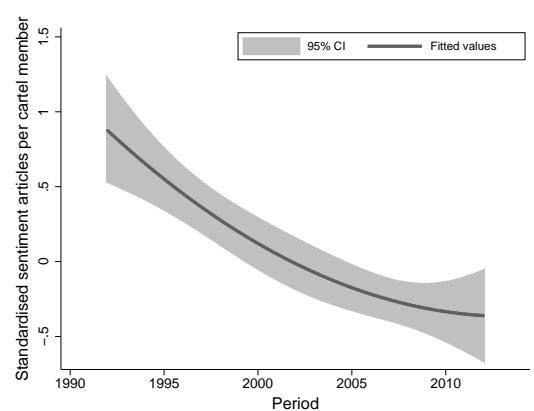

(d) Stdised sentiment

Figure B.1: Time trend of four key variables. Notes: The vertical axis shows our four main variables of interest (CAR, fine, exposure, sentiment). The plots show how these variables changed over our analysed period. 


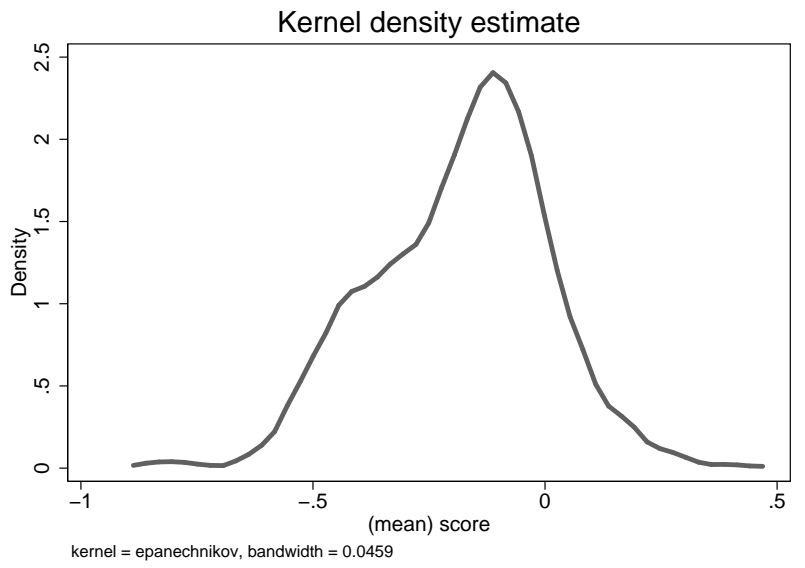

(a) Polar general

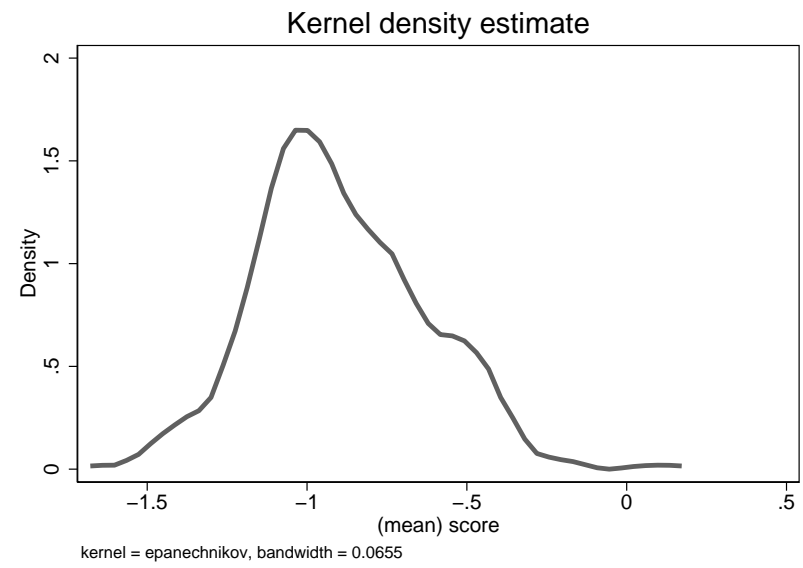

(b) Polar custom

Figure B.2: Kernel density of sentiment score. Notes: The left panel depicts the density of article-level sentiment scores based on the general lexicon; the right panel shows scores based on the custom lexicon. 


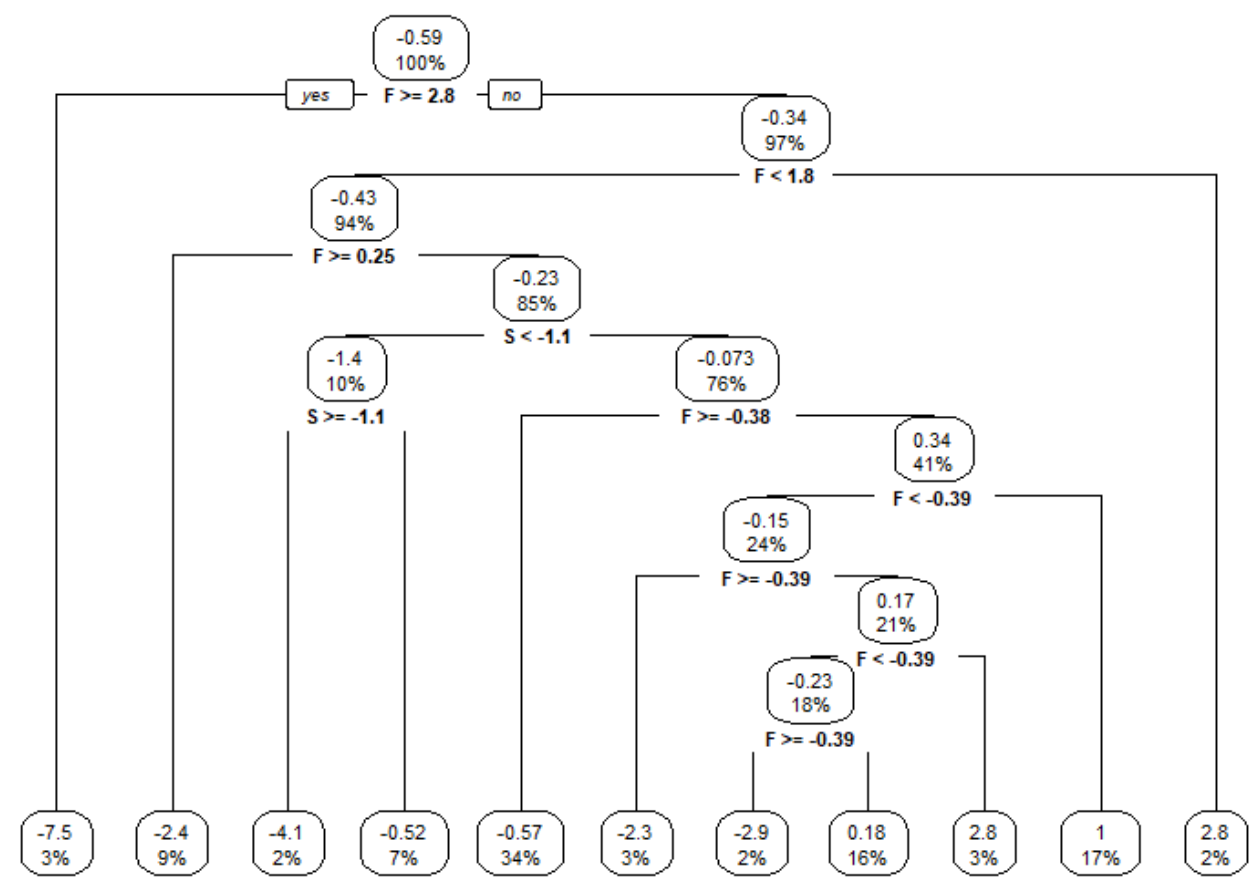

(a) CAR $[-1,1]$

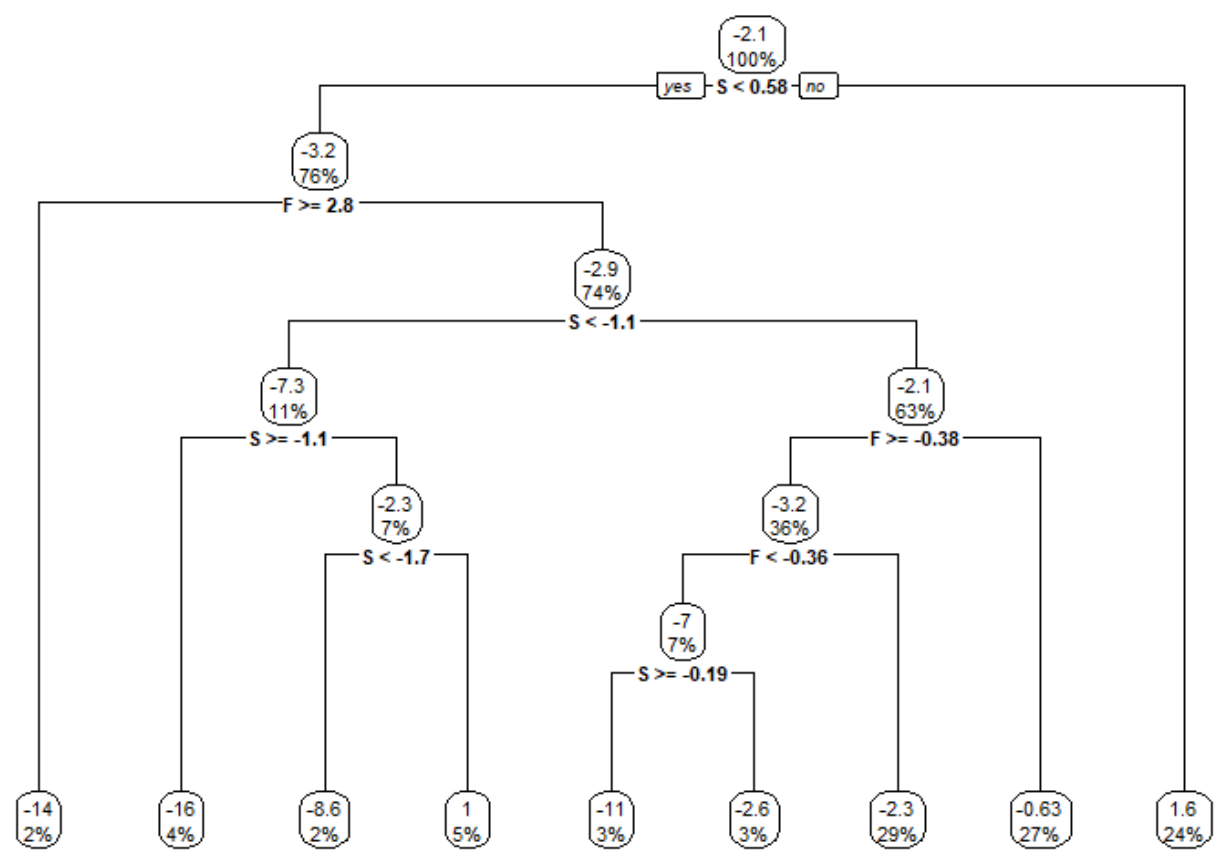

(b) CAR $[-10,10]$

Figure B.3: Regression tree including only E, F, S. Notes: The top panel highlights the effect in the proximity of the decision; the bottom panel on a wider time window. 


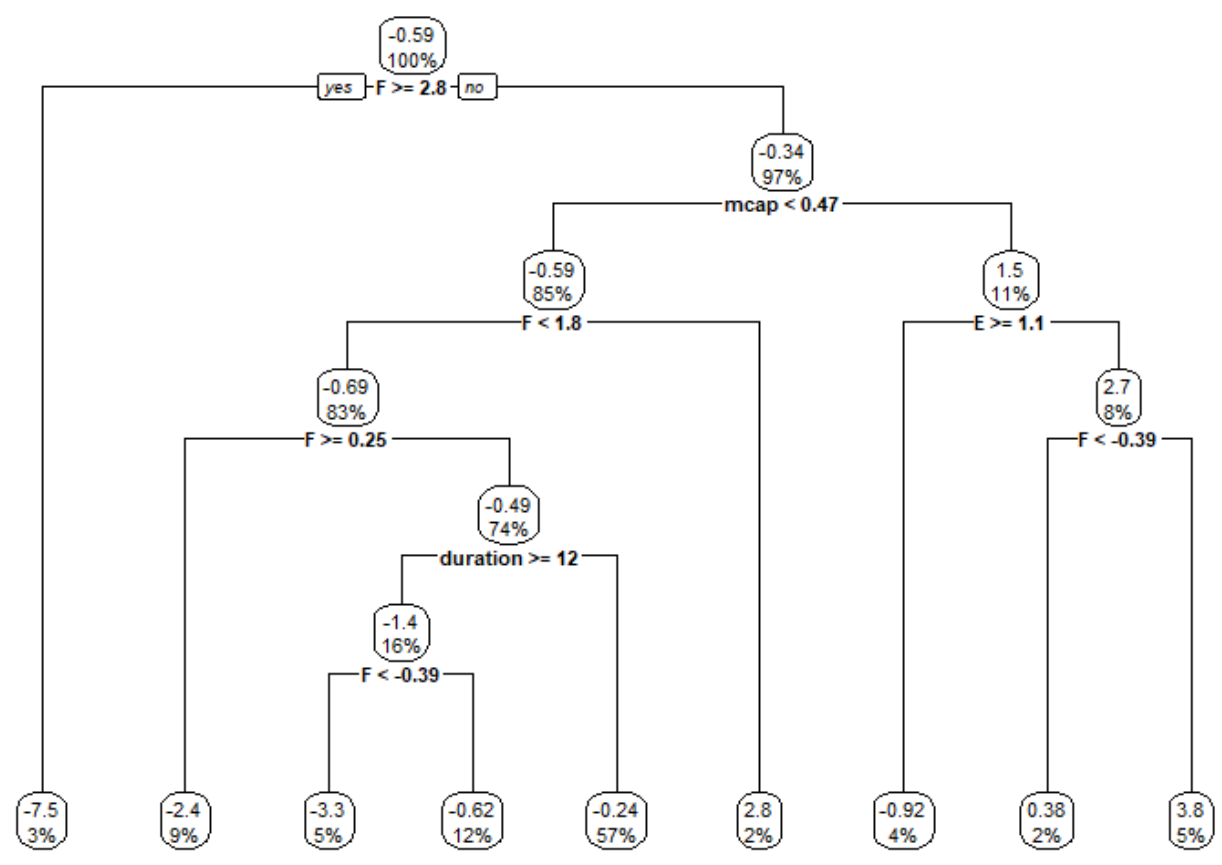

(a) CAR $[-1,1]$

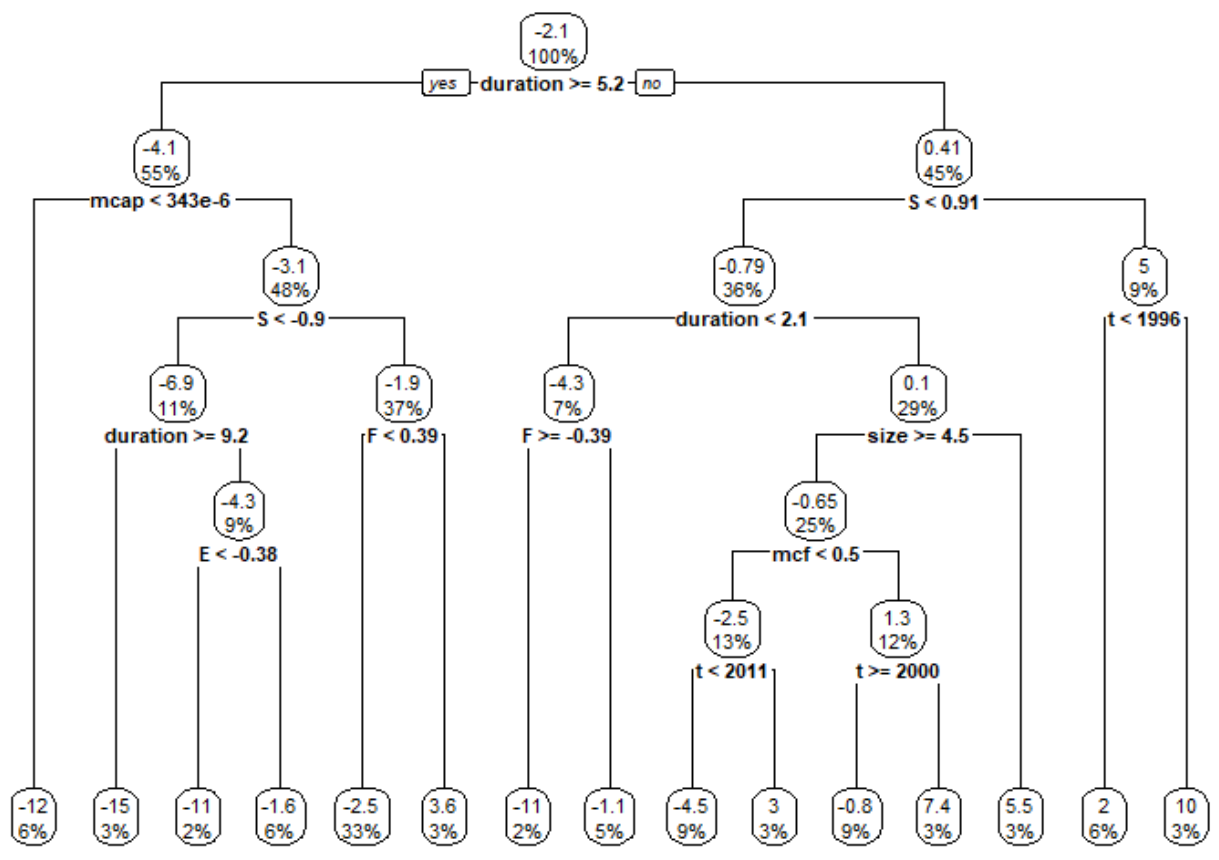

(b) CAR $[-10,10]$

Figure B.4: Regression tree including only E, F, S, time trend, and cartel and firm features. Notes: The top panel highlights the effect in the proximity of the decision; the bottom panel on a wider time window. 


\section{References}

Aguzzoni, Luca, Gregor Langus, and Massimo Motta, "The effect of EU antitrust investigations and fines on a firm's valuation,” The Journal of Industrial Economics, 2013, 61 (2), 290-338.

Alexander, Cindy R, "On the nature of the reputational penalty for corporate crime: evidence," The Journal of Law and Economics, 1999, 42 (S1), 489-526.

Allain, Marie-Laure, Marcel Boyer, Rachidi Kotchoni, and Jean-Pierre Ponssard, "Are cartel fines optimal? Theory and evidence from the European Union," International Review of Law and Economics, $2015,42,38-47$.

Armour, John, Colin Mayer, and Andrea Polo, "Regulatory sanctions and reputational damage in financial markets," Journal of Financial and Quantitative Analysis, 2017, 52 (4), 1429-1448.

Baker, Scott and Albert Choi, "Managing reputation with litigation: Why legal sanctions can work better than market sanctions," Mimeo 2013.

Baumol, William J, John C Panzar, and Robert D Willig, Contestable markets and the theory of industry structure, New York: New York: Harcourt Brace Jovanovich, 1982.

Bigoni, Maria, Sven-Olof Fridolfsson, Chloé Le Coq, and Giancarlo Spagnolo, "Fines, leniency, and rewards in antitrust," The RAND Journal of Economics, 2012, 43 (2), 368-390.

Boehmer, Ekkehart, Jim Masumeci, and Annette B Poulsen, "Event-study methodology under conditions of event-induced variance," Journal of Financial Economics, 1991, 30 (2), 253-272.

Brown, Stephen J and Jerold B Warner, "Measuring security price performance," Journal of Financial Economics, 1980, 8 (3), 205-258.

_ and _, "Using daily stock returns: The case of event studies," Journal of Financial Economics, 1985, $14(1), 3-31$.

Bruner, Robert F, "Does M\&A pay? A survey of evidence for the decision-maker," Journal of Applied Finance, 2002, 12 (1), 48-68.

Campbell, Cynthia J, Arnold R Cowan, and Valentina Salotti, "Multi-country event-study methods," Journal of Banking and Finance, 2010, 34 (12), 3078-3090.

Carree, Martin, Boris Lokshin, and René Belderbos, "A note on testing for complementarity and substitutability in the case of multiple practices," Journal of Productivity Analysis, 2011, 35 (3), 263-269.

Davies, Stephen and Oindrila De, "Ringleaders in larger number asymmetric cartels," The Economic Journal, 2013, 123 (572), F524-F544.

de Kauter, Marjan Van, Diane Breesch, and Véronique Hoste, "Fine-grained analysis of explicit and implicit sentiment in financial news articles," Expert Systems with Applications, 2015, 42 (11), 49995010 .

Fama, Eugene F, “The behavior of stock-market prices,” The Journal of Business, 1965, 38 (1), 34-105.

Fich, Eliezer M and Anil Shivdasani, "Financial fraud, director reputation, and shareholder wealth," Journal of Financial Economics, 2007, 86 (2), 306-336.

Ganuza, Juan José, Fernando Gomez, and Marta Robles, "Product liability versus reputation," The Journal of Law, Economics, and Organization, 2016, 32 (2), 213-241. 
Gonçalves, Carlos Adriano, Célia Talma Gonçalves, Rui Camacho, and Eugénio C Oliveira, “The impact of pre-processing on the classification of MEDLINE documents," in "PRIS" 2010, pp. 53-61.

González, Xulia and María J Moral, "Effects of antitrust prosecution on retail fuel prices," International Journal of Industrial Organization, 2019, 67 (102537), 1-18.

Graddy, Duane B and Thomas H Strickland, "Public information as a deterrent to environmental infractions," Applied Economics, 2007, 39 (15), 1961-1972.

Green, Edward J and Robert H Porter, "Noncooperative collusion under imperfect price information," Econometrica: Journal of the Econometric Society, 1984, pp. 87-100.

Gupta, Vishal and Gurpreet S Lehal, "A survey of text mining techniques and applications," Journal of Emerging Technologies in Web Intelligence, 2009, 1 (1), 60-76.

Hamilton, James T, "Pollution as news: Media and stock market reactions to the toxics release inventory data," Journal of Environmental Economics and Management, 1995, 28 (1), 98-113.

Hotho, Andreas, Andreas Nürnberger, and Gerhard Paaß, "A Brief Survey of Text Mining.," in "Ldv Forum," Vol. 20 2005, pp. 19-62.

Hu, Minqing and Bing Liu, "Mining and summarizing customer reviews," in "Proceedings of the tenth ACM SIGKDD international conference on Knowledge discovery and data mining" ACM 2004, pp. 168177.

Iacobucci, Edward, "On the interaction between legal and reputational sanctions," Journal of Legal Studies, 2014, 43, 189-207.

Jarrell, Gregg and Sam Peltzman, "The impact of product recalls on the wealth of sellers," Journal of Political Economy, 1985, 93 (3), 512-536.

Jones, Kari and Paul H Rubin, "Effects of harmful environmental events on reputations of firms," in "Advances in Financial Economics," Emerald Group Publishing Limited, 2001, pp. 161-182.

Jr, John R Lott, "Brand names, ignorance, and quality guaranteeing premiums," Applied Economics, 1988, 20 (2), 165-176.

Jr, Joseph E Harrington, “Optimal corporate leniency programs," The Journal of Industrial Economics, 2008, 56 (2), 215-246.

_ , "A proposal for a structural remedy for illegal collusion,” Antitrust Law Journal, Forthcoming, 2017.

Kahneman, Daniel and Amos Tversky, "Judgment under uncertainty: Heuristics and biases," Science, 1974, 185 (4157), 1124-1131.

Karpoff, Jonathan M and John R Lott Jr, "Reputational penalty firms bear from committing criminal fraud, the," Journal of Law and Economics, 1993, 36, 757.

_ D Scott Lee, and Gerald S Martin, “The consequences to managers for financial misrepresentation," Journal of Financial Economics, 2008, 88 (2), 193-215.

_, ,_, and Valaria P Vendrzyk, "Defense procurement fraud, penalties, and contractor influence," Journal of Political Economy, 1999, 107 (4), 809-842.

_, John R Lott Jr, and Eric W Wehrly, "The reputational penalties for environmental violations: Empirical evidence," Journal of Law and Economics, 2005, 48 (2), 653-675. 
Kaspereit, Thomas, "EVENTSTUDY2: Stata module to perform event studies with complex test statistics," 2016.

Klein, Benjamin and Keith B Leffler, "The role of market forces in assuring contractual performance," The Journal of Political Economy, 1981, pp. 615-641.

Kolari, James W and Seppo Pynnönen, "Event study testing with cross-sectional correlation of abnormal returns," Review of Financial Studies, 2010, 23 (11), 3996-4025.

Kothari, Sagar P and Jerold B Warner, "Econometrics of event studies," in "Handbook of empirical corporate finance," Elsevier, 2007, pp. 3-36.

Laplante, Benoit and Paul Lanoie, "The market response to environmental incidents in Canada: A theoretical and empirical analysis," Southern Economic Journal, 1994, pp. 657-672.

MacKinlay, A Craig, "Event studies in economics and finance," Journal of Economic Literature, 1997, 35 (1), 13-39.

Malkiel, Burton G and Eugene F Fama, "Efficient capital markets: A review of theory and empirical work," The Journal of Finance, 1970, 25 (2), 383-417.

Marvao, Catarina, Giancarlo Spagnolo et al., "Cartels and leniency: Taking stock of what we learnt," Handbook of Game Theory and Industrial Organization, Volume II: Applications, 2018, 2, 57.

McGuire, Jean B, Alison Sundgren, and Thomas Schneeweis, "Corporate social responsibility and firm financial performance," Academy of management Journal, 1988, 31 (4), 854-872.

Mitchell, Mark L and Michael T Maloney, "Crisis in the cockpit? The role of market forces in promoting air travel safety," The Journal of Law and Economics, 1989, 32 (2), 329-355.

Peltzman, Sam, “The effects of FTC advertising regulation," The Journal of Law and Economics, 1981, 24 (3), 403-448.

Polinsky, A Mitchell and Steven Shavell, "The optimal use of fines and imprisonment," Journal of Public Economics, 1984, 24 (1), 89-99.

Shapiro, Carl, "Premiums for high quality products as returns to reputations," The Quarterly Journal of Economics, 1983, pp. 659-679.

Shiller, Robert James, "Do stock prices move too much to be justified by subsequent changes in dividends," American Economic Review, 1981, 71, 421-436.

Smuda, Florian, "Cartel overcharges and the deterrent effect of EU competition law," Journal of Competition Law and Economics, 2013, 10 (1), 63-86.

Souam, Said, “Optimal antitrust policy under different regimes of fines," International Journal of Industrial Organization, 2001, 19 (1-2), 1-26.

Stephan, Andreas, “An empirical assessment of the European leniency notice," Journal of Competition Law \& Economics, 2008, 5, 537.

Vijayarani, S, Ms J Ilamathi, and Ms Nithya, "Preprocessing techniques for text mining-an overview," International Journal of Computer Science and Communication Networks, 2015, 5 (1), 7-16. 


\section{Online appendix}

Table C.1: Regression analysis of percentage CAR using custom sentiment score

CAR $[-1,1] \quad$ CAR $[-10,10] \quad$ CAR[-10,-1] CAR[1,10]

CAR $[-1,1] \quad$ CAR $[-10,10] \quad$ CAR $[-10,-1] \quad$ CAR $[1,10]$

no controls

with controls $\dagger$

\begin{tabular}{|c|c|c|c|c|c|c|c|c|}
\hline \multirow[b]{2}{*}{ cons } & \multicolumn{8}{|c|}{ linear regression } \\
\hline & $\begin{array}{l}-0.595^{* *} \\
(0.229)\end{array}$ & $\begin{array}{l}-2.072 * * * \\
(0.659)\end{array}$ & $\begin{array}{l}-1.110 * * \\
(0.438)\end{array}$ & $\begin{array}{l}-0.728 \\
(0.441)\end{array}$ & $\begin{array}{l}-0.606 \\
(0.894)\end{array}$ & $\begin{array}{l}0.260 \\
(2.845)\end{array}$ & $\begin{array}{l}0.075 \\
(2.014)\end{array}$ & $\begin{array}{l}0.289 \\
(2.106)\end{array}$ \\
\hline $\mathrm{E}$ & -0.176 & $0.946^{*}$ & 0.545 & 0.581 & -0.258 & $1.092 *$ & $0.785^{*}$ & 0.526 \\
\hline & $(0.205)$ & $(0.498)$ & $(0.395)$ & $(0.388)$ & $(0.224)$ & $(0.579)$ & $(0.442)$ & $(0.434)$ \\
\hline $\mathrm{F}$ & $-1.036 * * *$ & -0.969 & -0.389 & -0.034 & $-0.988 * * *$ & -0.721 & -0.394 & 0.194 \\
\hline S & $\begin{array}{l}(0.333) \\
0.160 \\
(0.243)\end{array}$ & $\begin{array}{l}(0.836) \\
2.375 * * * \\
(0.780)\end{array}$ & $\begin{array}{l}(0.583) \\
1.707 * * * \\
(0.566)\end{array}$ & $\begin{array}{l}(0.386) \\
0.397 \\
(0.552)\end{array}$ & $\begin{array}{l}(0.335) \\
0.216 \\
(0.278)\end{array}$ & $\begin{array}{l}(0.916) \\
2.141 * * \\
(0.898)\end{array}$ & $\begin{array}{l}(0.642) \\
1.442 * * \\
(0.671)\end{array}$ & $\begin{array}{l}(0.457) \\
0.368 \\
(0.575)\end{array}$ \\
\hline Joint F & $3.757 * *$ & $4.245^{* * *}$ & $3.552 * *$ & 0.798 & $2.929 * * *$ & $4.003 * * *$ & $4.230 * * *$ & $1.636^{*}$ \\
\hline $\mathrm{R}^{2}$ & 0.068 & 0.056 & 0.051 & 0.007 & 0.074 & 0.072 & 0.060 & 0.028 \\
\hline
\end{tabular}

\begin{tabular}{|c|c|c|c|c|c|c|c|c|}
\hline \multirow[b]{2}{*}{ cons } & \multicolumn{8}{|c|}{ linear regression with interactions } \\
\hline & $\begin{array}{l}-0.593 * * \\
(0.252)\end{array}$ & $\begin{array}{l}-2.480 * * * \\
(0.698)\end{array}$ & $\begin{array}{l}-1.200 * * \\
(0.479)\end{array}$ & $\begin{array}{l}-0.999 * * \\
(0.462)\end{array}$ & $\begin{array}{l}-0.523 \\
(0.898)\end{array}$ & $\begin{array}{l}0.706 \\
(2.901)\end{array}$ & $\begin{array}{l}0.664 \\
(1.985)\end{array}$ & $\begin{array}{l}-0.030 \\
(2.136)\end{array}$ \\
\hline \multirow[t]{2}{*}{$\mathrm{E}$} & -0.245 & 0.228 & 0.257 & 0.298 & -0.317 & 0.366 & 0.643 & 0.068 \\
\hline & $(0.246)$ & $(0.595)$ & $(0.444)$ & $(0.452)$ & $(0.282)$ & $(0.671)$ & $(0.490)$ & $(0.511)$ \\
\hline \multirow[t]{2}{*}{$\mathrm{F}$} & $-1.203 * * *$ & $-1.661 *$ & -0.715 & -0.176 & $-1.147 * * *$ & -1.416 & -0.708 & 0.041 \\
\hline & $(0.334)$ & $(0.885)$ & $(0.521)$ & $(0.537)$ & $(0.340)$ & $(0.915)$ & $(0.565)$ & $(0.584)$ \\
\hline \multirow[t]{2}{*}{ S } & 0.176 & $1.775 * *$ & $1.609 * * *$ & -0.053 & 0.207 & $1.592 *$ & $1.382 * *$ & -0.057 \\
\hline & $(0.272)$ & $(0.813)$ & $(0.592)$ & $(0.561)$ & $(0.297)$ & $(0.876)$ & $(0.678)$ & $(0.573)$ \\
\hline \multirow[t]{2}{*}{$\mathrm{EF}$} & -0.241 & -1.239 & -0.832 & 0.109 & -0.232 & -1.364 & -0.835 & 0.022 \\
\hline & $(0.482)$ & (1.186) & $(0.691)$ & $(0.825)$ & $(0.494)$ & (1.158) & $(0.717)$ & $(0.801)$ \\
\hline \multirow[t]{2}{*}{$\mathrm{ES}$} & -0.007 & $-1.389 *$ & -0.434 & -0.789 & -0.047 & $-1.456^{*}$ & -0.304 & $-0.966^{*}$ \\
\hline & $(0.272)$ & $(0.775)$ & $(0.505)$ & $(0.505)$ & $(0.294)$ & $(0.837)$ & $(0.567)$ & $(0.529)$ \\
\hline \multirow[t]{2}{*}{ FS } & -0.161 & -0.329 & 0.663 & -0.913 & -0.141 & -0.230 & 0.777 & -0.926 \\
\hline & $(0.382)$ & $(1.216)$ & $(0.715)$ & $(0.744)$ & $(0.400)$ & (1.199) & $(0.747)$ & (0.699) \\
\hline \multirow[t]{2}{*}{ EFS } & $-0.732 * *$ & $-2.955 *$ & -1.517 & -0.529 & $-0.683 *$ & $-2.936^{*}$ & -1.517 & -0.514 \\
\hline & $(0.369)$ & $(1.715)$ & $(1.015)$ & $(0.936)$ & $(0.386)$ & (1.669) & $(1.061)$ & $(0.885)$ \\
\hline Joint F & $2.421 * *$ & $4.137 * * *$ & $3.864 * * *$ & 1.346 & $2.329 * * *$ & $4.562 * * *$ & $4.817 * * *$ & $1.724 *$ \\
\hline $\mathrm{R}^{2}$ & 0.076 & 0.080 & 0.080 & 0.024 & 0.080 & 0.097 & 0.092 & 0.046 \\
\hline Obs & 287 & 287 & 287 & 287 & 287 & 287 & 287 & 287 \\
\hline
\end{tabular}

Notes: This table shows OLS regressions on the cumulative abnormal rate of return for the custom baseline measure of sentiment score. Significance level: ${ }^{a} p<0.01,{ }^{b} p<0.05,{ }^{c} p<0.10$. Clustered (by firm) standard error in parenthesis. $\dagger$ Controls: number of cartel members, cartel duration, dummy for observations with no data on cartel duration, dummy for recidivist firm, dummy indicating whether the firm received leniency, time trend, and firm market capitalisation (proxy for firm size). 
Table C.2: Regression analysis of percentage CAR using general sentiment score CAR[-1,1] CAR[-10,10] CAR[-10,-1] CAR[1,10] CAR[-1,1] CAR[-10,10] CAR[-10,-1] CAR[1,10] no controls with controls $\dagger$

\begin{tabular}{|c|c|c|c|c|c|c|c|c|}
\hline \multirow[b]{2}{*}{ cons } & \multicolumn{8}{|c|}{ linear regression } \\
\hline & $\begin{array}{l}-0.595^{* *} \\
(0.230)\end{array}$ & $\begin{array}{l}-2.072 * * * \\
(0.678)\end{array}$ & $\begin{array}{l}-1.110 * * \\
(0.443)\end{array}$ & $\begin{array}{l}-0.728 \\
(0.444)\end{array}$ & $\begin{array}{l}-0.693 \\
(0.905)\end{array}$ & $\begin{array}{l}-0.356 \\
(2.787)\end{array}$ & $\begin{array}{l}-0.182 \\
(1.939)\end{array}$ & $\begin{array}{l}0.082 \\
(2.095)\end{array}$ \\
\hline \multirow[t]{2}{*}{$\mathrm{E}$} & -0.214 & 0.426 & 0.247 & 0.439 & -0.279 & $1.017^{*}$ & $0.822 *$ & 0.457 \\
\hline & $(0.198)$ & $(0.511)$ & $(0.386)$ & $(0.374)$ & $(0.233)$ & $(0.575)$ & $(0.449)$ & $(0.436)$ \\
\hline \multirow[t]{2}{*}{$\mathrm{F}$} & $-1.037 * * *$ & -0.966 & -0.345 & -0.063 & $-0.993 * * *$ & -0.694 & -0.327 & 0.168 \\
\hline & $(0.332)$ & $(0.877)$ & $(0.632)$ & $(0.388)$ & $(0.332)$ & $(0.951)$ & $(0.690)$ & $(0.460)$ \\
\hline S & $\begin{array}{l}0.062 \\
(0.225)\end{array}$ & $\begin{array}{l}1.102 \\
(0.696)\end{array}$ & $\begin{array}{l}1.174 * \\
(0.632)\end{array}$ & $\begin{array}{l}-0.094 \\
(0.436)\end{array}$ & $\begin{array}{l}0.047 \\
(0.223)\end{array}$ & $\begin{array}{l}1.092 \\
(0.718)\end{array}$ & $\begin{array}{l}1.144 * \\
(0.657)\end{array}$ & $\begin{array}{l}-0.075 \\
(0.451)\end{array}$ \\
\hline \multirow{3}{*}{$\begin{array}{l}\text { Joint } \mathrm{F} \\
\mathrm{R}^{2}\end{array}$} & $3.671 * *$ & 1.635 & 1.629 & 0.557 & $2.816 * * *$ & $4.164 * * *$ & $4.281 * * *$ & $1.748^{*}$ \\
\hline & 0.067 & 0.021 & 0.027 & 0.004 & 0.072 & 0.053 & 0.056 & 0.026 \\
\hline & \multicolumn{8}{|c|}{ linear regression with interactions } \\
\hline cons & $\begin{array}{l}-0.586^{* *} \\
(0.235)\end{array}$ & $\begin{array}{l}-2.491 * * * \\
(0.713)\end{array}$ & $\begin{array}{l}-1.358 * * * \\
(0.508)\end{array}$ & $\begin{array}{l}-0.898^{*} \\
(0.456)\end{array}$ & $\begin{array}{l}-0.704 \\
(0.918)\end{array}$ & $\begin{array}{l}-0.263 \\
(2.875)\end{array}$ & $\begin{array}{l}0.086 \\
(1.913)\end{array}$ & $\begin{array}{l}-0.136 \\
(2.163)\end{array}$ \\
\hline $\mathrm{E}$ & $\begin{array}{l}-0.235 \\
(0.246)\end{array}$ & $\begin{array}{l}-0.503 \\
(0.598)\end{array}$ & $\begin{array}{l}-0.335 \\
(0.465)\end{array}$ & $\begin{array}{l}0.132 \\
(0.397)\end{array}$ & $\begin{array}{l}-0.305 \\
(0.271)\end{array}$ & $\begin{array}{l}0.002 \\
(0.654)\end{array}$ & $\begin{array}{l}0.260 \\
(0.506)\end{array}$ & $\begin{array}{l}0.031 \\
(0.464)\end{array}$ \\
\hline \multirow[t]{2}{*}{$\mathrm{F}$} & $-1.059 * * *$ & $-1.389^{*}$ & -0.634 & -0.154 & $-1.017 * * *$ & -1.090 & -0.582 & 0.071 \\
\hline & $(0.349)$ & $(0.735)$ & $(0.540)$ & $(0.385)$ & $(0.347)$ & $(0.772)$ & $(0.589)$ & $(0.436)$ \\
\hline \multirow[t]{2}{*}{ S } & 0.058 & 0.783 & 0.988 & -0.223 & 0.041 & 0.789 & 0.979 & -0.211 \\
\hline & $(0.225)$ & $(0.679)$ & $(0.621)$ & $(0.434)$ & $(0.224)$ & $(0.696)$ & $(0.644)$ & $(0.446)$ \\
\hline \multirow[t]{2}{*}{$\mathrm{EF}$} & -0.067 & $-2.331 *$ & $-2.015 *$ & -0.015 & -0.083 & $-2.543 * *$ & $-2.048 * *$ & -0.158 \\
\hline & $(0.588)$ & $(1.303)$ & (1.034) & $(0.659)$ & $(0.571)$ & $(1.288)$ & (1.031) & $(0.732)$ \\
\hline \multirow[t]{2}{*}{ ES } & 0.059 & $-1.671 * * *$ & $-1.032 * *$ & $-0.668 *$ & 0.030 & $-1.689 * * *$ & $-0.954 *$ & $-0.769 * *$ \\
\hline & $(0.225)$ & $(0.574)$ & $(0.473)$ & $(0.353)$ & $(0.227)$ & $(0.593)$ & $(0.504)$ & $(0.370)$ \\
\hline \multirow[t]{2}{*}{ FS } & -0.090 & $-1.460 *$ & -0.626 & $-0.759^{*}$ & -0.095 & -1.367 & -0.525 & $-0.765^{*}$ \\
\hline & $(0.314)$ & $(0.797)$ & $(0.562)$ & $(0.425)$ & $(0.320)$ & $(0.843)$ & $(0.592)$ & $(0.445)$ \\
\hline \multirow[t]{2}{*}{ EFS } & -0.224 & $-3.075 * * *$ & $-1.657 * *$ & $-1.211^{* *}$ & -0.218 & $-3.027 * * *$ & $-1.566^{*}$ & $-1.251 * *$ \\
\hline & $(0.391)$ & $(1.109)$ & $(0.830)$ & $(0.498)$ & $(0.393)$ & (1.097) & $(0.850)$ & $(0.513)$ \\
\hline Joint F & 1.722 & $2.487 * *$ & 1.308 & $3.351 * * *$ & $2.038 * *$ & $3.945 * * *$ & $3.212 * * *$ & $3.427 * * *$ \\
\hline $\mathrm{R}^{2}$ & 0.068 & 0.062 & 0.056 & 0.026 & 0.073 & 0.093 & 0.082 & 0.049 \\
\hline Obs & 287 & 287 & 287 & 287 & 287 & 287 & 287 & 287 \\
\hline
\end{tabular}

Notes: This table shows OLS regressions on the cumulative abnormal rate of return for the general measure of sentiment score. Significance level: ${ }^{a} p<0.01,{ }^{b} p<0.05,{ }^{c} p<0.10$. Clustered (by firm) standard error in parenthesis. †Controls: number of cartel members, cartel duration, dummy for observations with no data on cartel duration, dummy for recidivist firm, dummy indicating whether the firm received leniency, time trend, and firm market capitalisation (proxy for firm size). 
Table C.3: Regression analysis of percentage CAR using custom sentiment score and controlling for cartel dummies

CAR[-1,1] CAR[-10,10] CAR[-10,-1] CAR[1,10] CAR[-1,1] CAR[-10,10] CAR[-10,-1] CAR[1,10] no controls with controls $\dagger$

\begin{tabular}{|c|c|c|c|c|c|c|c|c|}
\hline \multirow[b]{2}{*}{ cons } & \multicolumn{8}{|c|}{ linear regression } \\
\hline & $-0.595^{b}$ & $\begin{array}{l}-2.072^{a} \\
(0.671)\end{array}$ & $\begin{array}{l}-1.110^{b} \\
(0.432)\end{array}$ & $\begin{array}{l}-0.728^{c} \\
(0.432)\end{array}$ & $\begin{array}{l}-0.679^{c} \\
(0.393)\end{array}$ & $\begin{array}{l}-2.154^{c} \\
(1.102)\end{array}$ & $\begin{array}{l}-0.659 \\
(0.889)\end{array}$ & $\begin{array}{l}-1.222 \\
(0.745)\end{array}$ \\
\hline $\mathrm{E}$ & $\begin{array}{l}-0.455 \\
(0.626)\end{array}$ & $\begin{array}{l}0.077 \\
(1.678)\end{array}$ & $\begin{array}{l}1.267 \\
(0.873)\end{array}$ & $\begin{array}{l}-0.931 \\
(1.285)\end{array}$ & $\begin{array}{l}-0.521 \\
(0.642)\end{array}$ & $\begin{array}{l}0.050 \\
(1.764)\end{array}$ & $\begin{array}{l}1.334 \\
(0.930)\end{array}$ & $\begin{array}{l}-0.992 \\
(1.359)\end{array}$ \\
\hline $\mathrm{F}$ & $-1.157^{a}$ & -1.594 & -0.707 & -0.260 & $-1.167^{a}$ & -1.568 & -0.810 & -0.120 \\
\hline & $(0.395)$ & $(0.979)$ & (0.805) & $(0.451)$ & $(0.404)$ & (1.033) & $(0.849)$ & $(0.470)$ \\
\hline S & $\begin{array}{l}0.326 \\
(0.570)\end{array}$ & $\begin{array}{l}0.871 \\
(1.812)\end{array}$ & $\begin{array}{l}0.283 \\
(0.808)\end{array}$ & $\begin{array}{l}0.179 \\
(1.320)\end{array}$ & $\begin{array}{l}0.280 \\
(0.602)\end{array}$ & $\begin{array}{l}0.903 \\
(1.845)\end{array}$ & $\begin{array}{l}0.326 \\
(0.797)\end{array}$ & $\begin{array}{l}0.207 \\
(1.358)\end{array}$ \\
\hline \multirow{3}{*}{$\begin{array}{l}\text { Joint } \mathrm{F} \\
\mathrm{R}^{2}\end{array}$} & $3.179^{b}$ & 1.030 & 0.925 & 0.282 & $2.083^{c}$ & $1.973^{c}$ & $3.574^{a}$ & 0.367 \\
\hline & 0.242 & 0.335 & 0.340 & 0.309 & 0.243 & 0.337 & 0.345 & 0.312 \\
\hline & \multicolumn{8}{|c|}{ linear regression with interactions } \\
\hline cons & -0.720 & $-2.288^{b}$ & -0.607 & $-1.614^{b}$ & -0.763 & -2.157 & -0.070 & $-2.009^{c}$ \\
\hline$F$ & $(0.496)$ & (1.157) & $(0.683)$ & $(0.782)$ & $(0.595)$ & $(1.633)$ & $(1.073)$ & $(1.092)$ \\
\hline $\mathrm{E}$ & $\begin{array}{l}-0.631 \\
(0.847)\end{array}$ & $\begin{array}{l}-0.020 \\
(2.118)\end{array}$ & $\begin{array}{l}2.145^{c} \\
(1.148)\end{array}$ & $\begin{array}{l}-2.116 \\
(1.482)\end{array}$ & $\begin{array}{l}-0.720 \\
(0.852)\end{array}$ & $\begin{array}{l}0.007 \\
(2.203)\end{array}$ & $\begin{array}{l}2.236^{c} \\
(1.199)\end{array}$ & $\begin{array}{l}-2.135 \\
(1543)\end{array}$ \\
\hline $\mathrm{F}$ & $-1.521^{a}$ & $-2.704^{a}$ & $-1.306^{b}$ & -0.460 & $-1.547^{a}$ & $-2.728^{a}$ & $-1.466^{b}$ & -0.302 \\
\hline$S$ & 0.084 & $\begin{array}{l}(0.981) \\
0.566\end{array}$ & $\begin{array}{l}(0.615) \\
1.620\end{array}$ & $\begin{array}{l}(0.667) \\
-1.918\end{array}$ & $\begin{array}{l}(0.396) \\
-0.009\end{array}$ & $\begin{array}{l}(1.044) \\
0.652\end{array}$ & $\begin{array}{l}(0.661) \\
1.674\end{array}$ & $\begin{array}{l}(0.726) \\
-1.807\end{array}$ \\
\hline & (1.077) & (3.069) & (1.684) & $(2.002)$ & (1.103) & (3.064) & (1.694) & $(2.013)$ \\
\hline EF & -0.476 & -2.190 & $-1.866^{c}$ & 0.269 & $\begin{array}{l}-0.459 \\
(0.624)\end{array}$ & $\begin{array}{l}-2.193 \\
(1.698)\end{array}$ & $-1.947^{c}$ & $\begin{array}{l}0.346 \\
(1391)\end{array}$ \\
\hline ES & -0.373 & -0.580 & 1.572 & $\begin{array}{l}(1.364) \\
-2.680\end{array}$ & $\begin{array}{l}(0.624) \\
-0.437\end{array}$ & $\begin{array}{l}1.090) \\
-0.522\end{array}$ & $\begin{array}{l}(1.011) \\
1.572\end{array}$ & $\begin{array}{l}(1.391) \\
-2.562\end{array}$ \\
\hline & $(1.422)$ & $(3.627)$ & (1.918) & $(2.493)$ & $(1.430)$ & (3.597) & (1.944) & $(2.478)$ \\
\hline FS & $\begin{array}{l}-0.598 \\
(0.506)\end{array}$ & $\begin{array}{l}-1.584 \\
(1.274)\end{array}$ & $\begin{array}{l}0.158 \\
(0.803)\end{array}$ & $\begin{array}{c}-1.588^{c} \\
(0.848)\end{array}$ & $\begin{array}{l}-0.593 \\
(0.523)\end{array}$ & $\begin{array}{l}-1.602 \\
(1.315)\end{array}$ & $\begin{array}{l}0.071 \\
(0.821)\end{array}$ & $\begin{array}{l}-1.519^{c} \\
(0872)\end{array}$ \\
\hline EFS & $\begin{array}{l}-1.219^{a} \\
(0.467)\end{array}$ & $\begin{array}{l}-3.560^{b} \\
(1.488)\end{array}$ & $\begin{array}{l}-2.062^{b} \\
(0.970)\end{array}$ & $\begin{array}{l}-0.393 \\
(1.068)\end{array}$ & $\begin{array}{l}-1.226^{b} \\
(0.472)\end{array}$ & $\begin{array}{l}-3.582^{b} \\
(1.515)\end{array}$ & $\begin{array}{l}-2.181^{b} \\
(0.992)\end{array}$ & $\begin{array}{l}-0.287 \\
(1.096)\end{array}$ \\
\hline Joint $\mathrm{F}$ & $2.691^{b}$ & 1.575 & $2.803^{a}$ & $1.917^{c}$ & $2.117^{b}$ & $1.906^{b}$ & $3.652^{a}$ & 1.370 \\
\hline $\mathrm{R}^{2}$ & 0.254 & 0.350 & 0.368 & 0.336 & 0.256 & 0.352 & 0.375 & 0.338 \\
\hline Obs & 287 & 287 & 287 & 287 & 287 & 287 & 287 & 287 \\
\hline
\end{tabular}


Table C.4: Regression analysis of percentage CAR (polar custom score) limited to the sample of manufacturing cartels.

CAR $[-1,1] \quad$ CAR $[-10,10] \quad$ CAR $[-10,-1] \quad$ CAR $[1,10] \quad$ CAR $[-1,1] \quad$ CAR $[-10,10] \quad$ CAR $[-10,-1] \quad$ CAR $[1,10]$ no controls with controls $\dagger$

\begin{tabular}{|c|c|c|c|c|c|c|c|c|}
\hline \multirow[b]{2}{*}{ cons } & \multicolumn{8}{|c|}{ linear regression } \\
\hline & $\begin{array}{l}-0.459^{c} \\
(0.262)\end{array}$ & $\begin{array}{l}-2.490^{a} \\
(0.745)\end{array}$ & $\begin{array}{l}-1.536^{a} \\
(0.493)\end{array}$ & $\begin{array}{l}-0.825 \\
(0.518)\end{array}$ & $\begin{array}{l}-0.164 \\
(1.345)\end{array}$ & $\begin{array}{l}0.024 \\
(3.874)\end{array}$ & $\begin{array}{l}1.792 \\
(2.663)\end{array}$ & $\begin{array}{l}-1.257 \\
(2.886)\end{array}$ \\
\hline $\mathrm{E}$ & $\begin{array}{l}-0.118 \\
(0.279)\end{array}$ & $\begin{array}{l}1.393^{b} \\
(0.684)\end{array}$ & $\begin{array}{l}1.165^{b} \\
(0.537)\end{array}$ & $\begin{array}{l}0.364 \\
(0.549)\end{array}$ & $\begin{array}{l}-0.068 \\
(0.353)\end{array}$ & $\begin{array}{l}1.944^{b} \\
(0.873)\end{array}$ & $\begin{array}{l}1.897^{a} \\
(0.678)\end{array}$ & $\begin{array}{l}0.187 \\
(0.679)\end{array}$ \\
\hline $\mathrm{F}$ & $\begin{array}{l}-1.081^{a} \\
(0.366)\end{array}$ & $\begin{array}{l}-0.834 \\
(0.937)\end{array}$ & $\begin{array}{l}-0.340 \\
(0.659)\end{array}$ & $\begin{array}{l}0.080 \\
(0.404)\end{array}$ & $\begin{array}{l}-1.012^{a} \\
(0.354)\end{array}$ & $\begin{array}{l}-0.475 \\
(1.054)\end{array}$ & $\begin{array}{l}-0.248 \\
(0.780)\end{array}$ & $\begin{array}{l}0.302 \\
(0.488)\end{array}$ \\
\hline S & $\begin{array}{l}0.302 \\
(0.312)\end{array}$ & $\begin{array}{l}2.541^{b} \\
(1.036)\end{array}$ & $\begin{array}{l}1.762^{b} \\
(0.789)\end{array}$ & $\begin{array}{l}0.382 \\
(0.739)\end{array}$ & $\begin{array}{l}0.168 \\
(0.362)\end{array}$ & $\begin{array}{l}1.386 \\
(1.110)\end{array}$ & $\begin{array}{l}1.408 \\
(0.891)\end{array}$ & $\begin{array}{l}-0.166 \\
(0.705)\end{array}$ \\
\hline \multirow{3}{*}{$\begin{array}{l}\text { Joint } F \\
\mathrm{R}^{2}\end{array}$} & $3.380^{b}$ & $3.724^{b}$ & $2.679^{c}$ & 0.206 & $2.585^{a}$ & $4.959^{a}$ & $4.517^{a}$ & $1.948^{b}$ \\
\hline & 0.091 & 0.058 & 0.054 & 0.004 & 0.102 & 0.100 & 0.077 & 0.041 \\
\hline & \multicolumn{8}{|c|}{ linear regression with interactions } \\
\hline cons & $\begin{array}{l}-0.543^{c} \\
(0.287)\end{array}$ & $\begin{array}{l}-3.141^{a} \\
(0.797)\end{array}$ & $\begin{array}{l}-1.858^{a} \\
(0.555)\end{array}$ & $\begin{array}{l}-1.046^{c} \\
(0.551)\end{array}$ & $\begin{array}{l}-0.127 \\
(1.352)\end{array}$ & $\begin{array}{l}0.583 \\
(4.021)\end{array}$ & $\begin{array}{l}2.293 \\
(2.698)\end{array}$ & $\begin{array}{l}-1.285 \\
(2.929)\end{array}$ \\
\hline $\mathrm{E}$ & $\begin{array}{l}-0.242 \\
(0.326)\end{array}$ & $\begin{array}{l}0.863 \\
(0.760)\end{array}$ & $\begin{array}{l}0.929 \\
(0.573)\end{array}$ & $\begin{array}{l}0.213 \\
(0.597)\end{array}$ & $\begin{array}{l}-0.198 \\
(0.394)\end{array}$ & $\begin{array}{l}1.361 \\
(0.897)\end{array}$ & $\begin{array}{l}1.696^{b} \\
(0.693)\end{array}$ & $\begin{array}{l}-0.055 \\
(0.699)\end{array}$ \\
\hline $\mathrm{F}$ & $-1.265^{a}$ & -1.523 & -0.615 & -0.136 & $-1.193^{a}$ & -1.100 & -0.481 & 0.102 \\
\hline & $(0.350)$ & $(0.955)$ & $(0.578)$ & $(0.560)$ & $(0.346)$ & $(0.995)$ & $(0.651)$ & $(0.602)$ \\
\hline $\mathrm{S}$ & 0.179 & 1.472 & $1.218^{c}$ & 0.019 & 0.132 & 0.846 & 1.076 & -0.316 \\
\hline & $(0.337)$ & (1.009) & $(0.721)$ & $(0.722)$ & $(0.368)$ & $(1.065)$ & $(0.842)$ & $(0.692)$ \\
\hline $\mathrm{EF}$ & $\begin{array}{l}-0.266 \\
(0.684)\end{array}$ & $\begin{array}{l}-1.938 \\
(1606)\end{array}$ & -0.970 & -0.597 & $\begin{array}{l}-0.299 \\
(0692)\end{array}$ & $\begin{array}{l}-2.122 \\
(1563)\end{array}$ & $\begin{array}{l}-0.952 \\
(1059)\end{array}$ & -0.778 \\
\hline ES & $\begin{array}{l}(0.004) \\
-0.267\end{array}$ & $-2.395^{b}$ & $-1.070^{c}$ & $\begin{array}{l}(1.105) \\
-1.005\end{array}$ & $\begin{array}{l}(0.092) \\
-0.124\end{array}$ & -1.727 & $\begin{array}{l}(1.059) \\
-0.889\end{array}$ & -0.702 \\
\hline 20 & $(0.391)$ & (1.089) & $(0.620)$ & $(0.776)$ & $(0.437)$ & $(1.270)$ & $(0.789)$ & $(0.831)$ \\
\hline FS & -0.225 & -0.406 & 0.714 & -1.067 & -0.181 & -0.208 & 0.851 & -1.024 \\
\hline \multirow{3}{*}{ EFS } & $(0.404)$ & (1.194) & $(0.648)$ & $(0.811)$ & $(0.410)$ & $(1.205)$ & $(0.696)$ & $(0.787)$ \\
\hline & $-0.866^{c}$ & -2.850 & $\begin{array}{l}-1.545 \\
0.036\end{array}$ & -0.311 & $\begin{array}{l}-0.832^{c} \\
(0.436)\end{array}$ & -2.656 & -1.480 & -0.222 \\
\hline & $(0.442)$ & (1.764) & $(0.936)$ & (1.161) & $(0.436)$ & (1.849) & (1.012) & (1.241) \\
\hline \multirow{2}{*}{$\begin{array}{l}\text { Joint } F \\
\mathrm{R}^{2}\end{array}$} & $2.337^{b}$ & $3.357^{a}$ & $3.911^{a}$ & 0.734 & 2.211 & 4.689 & 5.356 & 1.460 \\
\hline & 0.103 & 0.096 & 0.097 & 0.023 & 0.112 & 0.129 & 0.120 & 0.055 \\
\hline Obs & 206 & 206 & 206 & 206 & 206 & 206 & 206 & 206 \\
\hline
\end{tabular}


Table C.5: Regression analysis of percentage CAR (squared polar custom score)

CAR[-1,1] CAR[-10,10] CAR[-10,-1] CAR[1,10]

CAR $[-1,1] \quad$ CAR $[-10,10] \quad$ CAR[-10,-1]

CAR $[1,10]$

no controls

with controls $\dagger$

\begin{tabular}{|c|c|c|c|c|c|c|c|c|}
\hline \multirow[b]{2}{*}{ cons } & \multicolumn{8}{|c|}{ linear regression } \\
\hline & $\begin{array}{l}-0.595^{b} \\
(0.229)\end{array}$ & $\begin{array}{l}-2.072^{a} \\
(0.662)\end{array}$ & $\begin{array}{l}-1.110^{b} \\
(0.435)\end{array}$ & $\begin{array}{l}-0.728 \\
(0.443)\end{array}$ & $\begin{array}{c}-0.662 \\
(0.897)\end{array}$ & $\begin{array}{l}-0.345 \\
(2.764)\end{array}$ & $\begin{array}{l}-0.267 \\
(1.959)\end{array}$ & $\begin{array}{l}0.127 \\
(2.095)\end{array}$ \\
\hline $\mathrm{E}$ & -0.167 & $0.956^{c}$ & 0.628 & 0.515 & -0.253 & $1.094^{c}$ & $0.833^{c}$ & 0.485 \\
\hline$F$ & $(0.204)$ & $(0.504)$ & $(0.404)$ & $(0.396)$ & $(0.226)$ & $(0.582)$ & $(0.445)$ & $(0.438)$ \\
\hline $\mathrm{F}$ & $\begin{array}{l}-1.038^{\circ} \\
(0.334)\end{array}$ & $\begin{array}{l}-1.007 \\
(0.837)\end{array}$ & $\begin{array}{l}-0.408 \\
(0.577)\end{array}$ & $\begin{array}{l}-0.047 \\
(0.388)\end{array}$ & $\begin{array}{l}-0.991^{a} \\
(0.336)\end{array}$ & $\begin{array}{l}-0.760 \\
(0.915)\end{array}$ & $\begin{array}{l}-0.410 \\
(0.633)\end{array}$ & $\begin{array}{l}0.179 \\
(0.459)\end{array}$ \\
\hline S & $\begin{array}{l}0.188 \\
(0.241)\end{array}$ & $\begin{array}{l}2.366^{a} \\
(0.817)\end{array}$ & $\begin{array}{l}1.940^{a} \\
(0.636)\end{array}$ & $\begin{array}{l}0.181 \\
(0.538)\end{array}$ & $\begin{array}{l}0.238 \\
(0.268)\end{array}$ & $\begin{array}{l}2.083^{b} \\
(0.880)\end{array}$ & $\begin{array}{l}1.717^{b} \\
(0.726)\end{array}$ & $\begin{array}{l}0.078 \\
(0.563)\end{array}$ \\
\hline \multirow{3}{*}{$\begin{array}{l}\text { Joint } F \\
\mathrm{R}^{2}\end{array}$} & $3.789^{b}$ & $3.798^{b}$ & $3.481^{b}$ & 0.604 & $2.955^{a}$ & $3.949^{a}$ & $4.077^{a}$ & $1.701^{c}$ \\
\hline & 0.069 & 0.056 & 0.064 & 0.005 & 0.075 & 0.072 & 0.073 & 0.026 \\
\hline & \multicolumn{8}{|c|}{ linear regression with interactions } \\
\hline cons & $\begin{array}{l}-0.580^{b} \\
(0.243)\end{array}$ & $\begin{array}{l}-2.542^{a} \\
(0.690)\end{array}$ & $\begin{array}{l}-1.315^{a} \\
(0.479)\end{array}$ & $\begin{array}{l}-0.937^{b} \\
(0.465)\end{array}$ & $\begin{array}{c}-0.596 \\
(0.901)\end{array}$ & $\begin{array}{l}-0.003 \\
(2.817)\end{array}$ & $\begin{array}{l}0.223 \\
(1.924)\end{array}$ & $\begin{array}{l}-0.175 \\
(2.122)\end{array}$ \\
\hline $\mathrm{E}$ & -0.200 & 0.157 & 0.213 & 0.271 & -0.272 & 0.276 & 0.536 & 0.082 \\
\hline $\mathrm{F}$ & $\begin{array}{l}(0.24 /) \\
-1.158^{a}\end{array}$ & $\begin{array}{l}(0.582) \\
-1.833^{b}\end{array}$ & $\begin{array}{l}(0.442) \\
-0.929^{c}\end{array}$ & $\begin{array}{l}(0.441) \\
-0.144\end{array}$ & $\begin{array}{l}(0.280) \\
-1.105^{a}\end{array}$ & $\begin{array}{l}(0.053) \\
-1.582^{c}\end{array}$ & $\begin{array}{l}(0.4 / 3) \\
-0.921^{c}\end{array}$ & $\begin{array}{l}(0.491) \\
0.076\end{array}$ \\
\hline & $(0.354)$ & $(0.837)$ & $(0.508)$ & $(0.552)$ & $(0.361)$ & $(0.883)$ & $(0.545)$ & $(0.614)$ \\
\hline S & 0.220 & $2.061^{a}$ & $1.851^{a}$ & -0.017 & 0.249 & $1.881^{b}$ & $1.649^{b}$ & -0.030 \\
\hline & $(0.242)$ & $(0.731)$ & $(0.592)$ & $(0.506)$ & $(0.267)$ & $(0.794)$ & $(0.688)$ & $(0.536)$ \\
\hline $\mathrm{EF}$ & $\begin{array}{c}-0.134 \\
(0.528)\end{array}$ & $\begin{array}{l}-1.424 \\
(1.215)\end{array}$ & $\begin{array}{l}-1.039 \\
(0.761)\end{array}$ & $\begin{array}{l}0.056 \\
0.809)\end{array}$ & $\begin{array}{c}-0.119 \\
(0.535)\end{array}$ & $\begin{array}{l}-1.494 \\
(1.193)\end{array}$ & $\begin{array}{c}-1.032 \\
(0.782)\end{array}$ & $\begin{array}{l}0.002 \\
(0.812)\end{array}$ \\
\hline ES & 0.057 & $-1.393^{b}$ & -0.641 & -0.595 & 0.025 & $-1.380^{b}$ & -0.510 & $-0.703^{\circ}$ \\
\hline $5 \mathrm{C}$ & $(0.217)$ & $(0.564)$ & $(0.395)$ & $(0.384)$ & $(0.233)$ & $(0.609)$ & $(0.448)$ & $(0.413)$ \\
\hline FS & $\begin{array}{l}-0.039 \\
(0.371)\end{array}$ & $\begin{array}{l}-0.129 \\
(0.874)\end{array}$ & $\begin{array}{l}0.595 \\
(0.575)\end{array}$ & $\begin{array}{l}-0.807 \\
(0.607)\end{array}$ & $\begin{array}{l}-0.012 \\
(0.386\end{array}$ & $\begin{array}{l}-0.018 \\
(0.869)\end{array}$ & $\begin{array}{l}0.683 \\
(0.594)\end{array}$ & $\begin{array}{l}-0.793 \\
(0.592)\end{array}$ \\
\hline EFS & -0.476 & $-2.930^{a}$ & $\begin{array}{l}-1.749^{b} \\
0745\end{array}$ & -0.477 & -0.444 & $-2.897^{a}$ & $-1.763^{b}$ & -0.435 \\
\hline Joint F & $2.162^{b}$ & $4.170^{a}$ & $3.754^{a}$ & 1.450 & $2.252^{a}$ & $4.430^{a}$ & $4.662^{a}$ & $1.788^{b}$ \\
\hline $\mathrm{R}^{2}$ & 0.074 & 0.092 & 0.098 & 0.022 & 0.079 & 0.107 & 0.107 & 0.043 \\
\hline Obs & 287 & 287 & 287 & 287 & 287 & 287 & 287 & 287 \\
\hline
\end{tabular}

Notes: This table shows OLS regressions on the cumulative abnormal rate of return, using a squared version of custom sentiment score (preserving original sign). Significance level: ${ }^{a} p<0.01,{ }^{b} p<0.05,{ }^{c} p<0.10$. Clustered (by firm) standard error in parenthesis. †Controls: number of cartel members, cartel duration, dummy for observations with no data on cartel duration, dummy for recidivist firm, dummy indicating whether the firm received leniency, time trend, and firm market capitalisation (proxy for firm size). 
Table C.6: Regression analysis of percentage CAR (polar custom score) limited to cartels convicted before 2005.

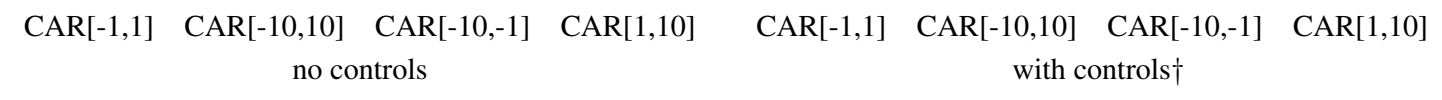

\begin{tabular}{|c|c|c|c|c|c|c|c|c|}
\hline \multirow[b]{2}{*}{ cons } & \multicolumn{8}{|c|}{ linear regression } \\
\hline & $\begin{array}{l}-0.256 \\
(0.355)\end{array}$ & $\begin{array}{l}-1.048 \\
(0.889)\end{array}$ & $\begin{array}{l}-0.445 \\
(0.683)\end{array}$ & $\begin{array}{l}-0.307 \\
(0.579)\end{array}$ & $\begin{array}{l}-0.364 \\
(1.353)\end{array}$ & $\begin{array}{l}0.801 \\
(4.559)\end{array}$ & $\begin{array}{l}0.318 \\
(2.864)\end{array}$ & $\begin{array}{l}0.527 \\
(3.533)\end{array}$ \\
\hline $\mathrm{E}$ & 0.672 & 1.958 & 0.707 & 1.421 & 0.514 & $2.694^{c}$ & 1.184 & 1.779 \\
\hline & $(0.614)$ & $(1.435)$ & (1.151) & $(1.012)$ & $(0.706)$ & $(1.584)$ & $(1.219)$ & $(1.215)$ \\
\hline $\mathrm{F}$ & -0.796 & -0.457 & -0.194 & 0.148 & -0.721 & -0.062 & -0.058 & 0.408 \\
\hline$S$ & $\begin{array}{l}(0.530) \\
0.163\end{array}$ & $\begin{array}{l}(1.245) \\
2.651^{a}\end{array}$ & $\begin{array}{l}(0.686) \\
1345^{b}\end{array}$ & $\begin{array}{l}(0.755) \\
0.925\end{array}$ & $\begin{array}{l}(0.525) \\
0.271\end{array}$ & $\begin{array}{l}(1.300) \\
2359^{c}\end{array}$ & $\begin{array}{l}(0.750) \\
0.883\end{array}$ & $\begin{array}{l}(0.815) \\
0.949\end{array}$ \\
\hline S & $(0.330)$ & $(0.961)$ & $(0.636)$ & $(0.749)$ & $(0.366)$ & $(1.250)$ & $(0.783)$ & $(0.739)$ \\
\hline \multirow{3}{*}{$\begin{array}{l}\text { Joint F } \\
\mathrm{R}^{2}\end{array}$} & 1.094 & $3.097^{b}$ & $2.702^{b}$ & 0.832 & 0.756 & $1.858^{c}$ & 0.941 & 1.217 \\
\hline & 0.025 & 0.070 & 0.036 & 0.017 & 0.050 & 0.104 & 0.053 & 0.088 \\
\hline & \multicolumn{8}{|c|}{ linear regression with interactions } \\
\hline cons & $\begin{array}{l}-0.441 \\
(0.524)\end{array}$ & $\begin{array}{l}-1.323 \\
(1.091)\end{array}$ & $\begin{array}{l}-0.247 \\
(0.725)\end{array}$ & $\begin{array}{l}-0.615 \\
(0.783)\end{array}$ & $\begin{array}{l}-0.556 \\
(1.431)\end{array}$ & $\begin{array}{l}1.362 \\
(4.960)\end{array}$ & $\begin{array}{l}2.323 \\
(2.748)\end{array}$ & $\begin{array}{c}-0.912 \\
(4.129)\end{array}$ \\
\hline \multirow[t]{2}{*}{$\mathrm{E}$} & 0.395 & 1.593 & 0.650 & 1.449 & 0.220 & 2.620 & 2.056 & 1.300 \\
\hline & $(0.820)$ & (1.779) & (1.197) & $(1.338)$ & $(1.036)$ & $(2.289)$ & $(1.439)$ & (1.791) \\
\hline \multirow[t]{2}{*}{$\mathrm{F}$} & -0.408 & -1.156 & -0.404 & -0.594 & -0.127 & -0.863 & -0.884 & -0.001 \\
\hline & $(0.728)$ & (1.691) & $(0.830)$ & $(1.740)$ & $(0.755)$ & $(2.052)$ & $(1.043)$ & (1.953) \\
\hline \multirow[t]{2}{*}{ S } & -0.320 & 1.748 & 1.550 & 0.279 & -0.120 & 1.839 & 2.056 & -0.090 \\
\hline & $(0.872)$ & $(1.678)$ & (1.069) & (1.192) & $(0.968)$ & $(2.102)$ & $(1.281)$ & $(1.570)$ \\
\hline \multirow[t]{2}{*}{$\mathrm{EF}$} & 1.141 & -0.148 & -0.113 & -0.416 & 1.459 & -0.594 & -1.171 & 0.001 \\
\hline & (1.036) & $(2.290)$ & (1.028) & $(2.325)$ & (1.104) & $(2.523)$ & (1.190) & $(2.530)$ \\
\hline \multirow[t]{2}{*}{$\mathrm{ES}$} & -0.695 & -1.401 & 0.110 & -0.830 & -0.561 & -0.854 & 1.558 & -1.438 \\
\hline & (1.109) & (2.391) & (1.442) & (1.733) & (1.215) & (3.272) & (1.980) & $(2.231)$ \\
\hline \multirow[t]{2}{*}{ FS } & -0.183 & -1.840 & 1.031 & -3.853 & -0.026 & -1.462 & 0.028 & -2.724 \\
\hline & $(1.470)$ & $(2.676)$ & $(1.443)$ & (2.788) & $(1.566)$ & $(3.302)$ & $(1.794)$ & (3.087) \\
\hline \multirow[t]{2}{*}{ EFS } & -1.152 & -4.270 & -1.465 & -3.105 & -0.880 & -4.036 & -3.040 & -1.627 \\
\hline & $(1.875)$ & $(3.629)$ & $(1.921)$ & (3.686) & (1.983) & $(4.405)$ & $(2.343)$ & $(4.072)$ \\
\hline Joint F & 0.842 & $5.133^{a}$ & $5.406^{a}$ & $3.918^{a}$ & 0.707 & $4.038^{a}$ & $4.225^{a}$ & $3.284^{a}$ \\
\hline $\mathrm{R}^{2}$ & 0.045 & 0.084 & 0.090 & 0.058 & 0.070 & 0.120 & 0.120 & 0.124 \\
\hline Obs & 148 & 148 & 148 & 148 & 148 & 148 & 148 & 148 \\
\hline
\end{tabular}

Notes: This table shows OLS regressions on the cumulative abnormal rate of return, using the custom sentiment lexicon, where the analysis is limited to cartels convicted before 2005. Significance level: ${ }^{a} p<0.01,{ }^{b} p<0.05,{ }^{c} p<0.10$. Clustered (by firm) standard error in parenthesis. †Controls: number of cartel members, cartel duration, dummy for observations with no data on cartel duration, dummy for recidivist firm, dummy indicating whether the firm received leniency, time trend, and firm market capitalisation (proxy for firm size). 
Table C.7: Regression analysis of percentage CAR (polar custom score) limited to cartels convicted after 2004

CAR $[-1,1] \quad$ CAR $[-10,10] \quad$ CAR[-10,-1] CAR[1,10] CAR[-1,1] CAR[-10,10] CAR[-10,-1] CAR[1,10] no controls with controls $\dagger$

\begin{tabular}{|c|c|c|c|c|c|c|c|c|}
\hline \multirow[b]{2}{*}{ cons } & \multicolumn{8}{|c|}{ linear regression } \\
\hline & $\begin{array}{l}-0.358 \\
(0.370)\end{array}$ & $\begin{array}{l}-2.946^{a} \\
(1.076)\end{array}$ & $\begin{array}{l}-1.686^{b} \\
(0.672)\end{array}$ & $\begin{array}{l}-1.064 \\
(0.674)\end{array}$ & $\begin{array}{l}2.539 \\
(2.934)\end{array}$ & $\begin{array}{l}-2.743 \\
(9.024)\end{array}$ & $\begin{array}{l}-1.878 \\
(5.739)\end{array}$ & $\begin{array}{l}-2.431 \\
(6.016)\end{array}$ \\
\hline $\mathrm{E}$ & -0.343 & $1.192^{c}$ & 0.862 & 0.551 & -0.353 & 0.814 & 0.729 & 0.305 \\
\hline & $(0.238)$ & $(0.660)$ & $(0.531)$ & $(0.475)$ & $(0.247)$ & $(0.616)$ & $(0.494)$ & $(0.479)$ \\
\hline $\mathrm{F}$ & $-1.184^{a}$ & -1.103 & -0.454 & -0.050 & $-1.183^{a}$ & -0.918 & -0.432 & 0.099 \\
\hline & $(0.428)$ & (1.031) & $(0.756)$ & $(0.444)$ & $(0.428)$ & (1.196) & $(0.903)$ & $(0.526)$ \\
\hline S & $\begin{array}{l}0.451 \\
(0.446)\end{array}$ & $\begin{array}{l}1.926 \\
(1.357)\end{array}$ & $\begin{array}{l}2.062^{b} \\
(1.021)\end{array}$ & $\begin{array}{l}-0.287 \\
(0.828)\end{array}$ & $\begin{array}{l}0.345 \\
(0.471)\end{array}$ & $\begin{array}{l}1.968 \\
(1.380)\end{array}$ & $\begin{array}{l}2.027^{c} \\
(1.048)\end{array}$ & $\begin{array}{c}-0.176 \\
(0.860)\end{array}$ \\
\hline \multirow{3}{*}{$\begin{array}{l}\text { Joint F } \\
\mathrm{R}^{2}\end{array}$} & $3.553^{b}$ & 1.907 & 1.572 & 0.706 & $3.028^{a}$ & $2.685^{a}$ & $3.272^{a}$ & 1.274 \\
\hline & 0.145 & 0.046 & 0.063 & 0.010 & 0.159 & 0.063 & 0.074 & 0.034 \\
\hline & \multicolumn{8}{|c|}{ linear regression with interactions } \\
\hline cons & $\begin{array}{l}-0.393 \\
(0.371)\end{array}$ & $\begin{array}{l}-3.436^{a} \\
(1.124)\end{array}$ & $\begin{array}{c}-1.944^{b} \\
(0.743)\end{array}$ & $\begin{array}{c}-1.240^{c} \\
(0.699)\end{array}$ & $\begin{array}{l}2.726 \\
(2.942)\end{array}$ & $\begin{array}{l}-6.506 \\
(9.241)\end{array}$ & $\begin{array}{l}-3.488 \\
(5.826)\end{array}$ & $\begin{array}{l}-4.645 \\
(6.141)\end{array}$ \\
\hline \multirow[t]{2}{*}{$\mathrm{E}$} & -0.468 & 0.259 & 0.513 & 0.098 & -0.442 & -0.426 & 0.303 & -0.404 \\
\hline & $(0.303)$ & $(0.796)$ & $(0.597)$ & $(0.539)$ & $(0.336)$ & $(0.860)$ & $(0.656)$ & $(0.609)$ \\
\hline $\mathrm{F}$ & $\begin{array}{l}-1.319^{a} \\
(0.405)\end{array}$ & $-1.931^{c}$ & -0.664 & -0.522 & $\begin{array}{l}-1.303^{a} \\
(0.406)\end{array}$ & $\begin{array}{l}-1.685 \\
(1.082)\end{array}$ & -0.595 & -0.374 \\
\hline \multirow[t]{2}{*}{ S } & 0.400 & $\begin{array}{l}1.725 \\
1.72)\end{array}$ & $1.940^{c}$ & $\begin{array}{l}(0.300) \\
-0.314\end{array}$ & $\begin{array}{l}(0.400) \\
0.308\end{array}$ & $\begin{array}{l}(1.082) \\
1.753\end{array}$ & $1.899^{c}$ & $\begin{array}{l}(0.480) \\
-0.209\end{array}$ \\
\hline & $(0.440)$ & $(1.258)$ & $(0.991)$ & $(0.774)$ & $(0.465)$ & (1.264) & $(0.986)$ & $(0.790)$ \\
\hline $\mathrm{EF}$ & -0.399 & -2.015 & -1.125 & -0.257 & -0.438 & -2.425 & -1.242 & -0.461 \\
\hline \multirow{2}{*}{ ES } & $\begin{array}{l}(0.5 / 9) \\
-0.128\end{array}$ & $\begin{array}{l}(1.802) \\
-1.744^{c}\end{array}$ & $\begin{array}{l}(1.20 /) \\
-0.729\end{array}$ & $\begin{array}{l}(0.9 / 0) \\
-0.919^{c}\end{array}$ & $\begin{array}{l}(0.01 /) \\
-0.024\end{array}$ & $\begin{array}{l}(1.825) \\
-2.301^{b}\end{array}$ & $\begin{array}{l}(1.327) \\
-0.805\end{array}$ & $\begin{array}{l}(1.023) \\
-1.482^{b}\end{array}$ \\
\hline & $\begin{array}{l}-0.120 \\
(0.353)\end{array}$ & $(0.984)$ & $(0.733)$ & $(0.541)$ & $(0.381)$ & $(1.090)$ & $(0.853)$ & $(0.630)$ \\
\hline \multirow[t]{2}{*}{ FS } & -0.366 & 0.367 & 0.462 & 0.154 & -0.368 & 0.322 & 0.353 & 0.239 \\
\hline & $(0.508)$ & (1.549) & $(0.980)$ & $(0.706)$ & $(0.546)$ & (1.514) & $(1.085)$ & $(0.659)$ \\
\hline EFS & $\begin{array}{l}-0.635 \\
(0.633)\end{array}$ & $\begin{array}{l}-4.527^{c} \\
(2.474)\end{array}$ & $\begin{array}{l}-1.428 \\
(1.709)\end{array}$ & $\begin{array}{l}-2.281^{b} \\
(1.070)\end{array}$ & $\begin{array}{l}-0.586 \\
(0.645)\end{array}$ & $\begin{array}{l}-4.657^{b} \\
(2.312)\end{array}$ & $\begin{array}{l}-1.419 \\
(1.771)\end{array}$ & $\begin{array}{l}-2.436^{a} \\
(0.912)\end{array}$ \\
\hline Joint F & $3.189^{a}$ & 1.491 & 0.964 & $1.992^{c}$ & $3.092^{a}$ & $2.628^{a}$ & $2.622^{a}$ & $2.675^{a}$ \\
\hline $\mathrm{R}^{2}$ & 0.154 & 0.091 & 0.080 & 0.045 & 0.168 & 0.114 & 0.090 & 0.080 \\
\hline Obs & 139 & 139 & 139 & 139 & 139 & 139 & 139 & 139 \\
\hline
\end{tabular}

Notes: This table shows OLS regressions on the cumulative abnormal rate of return, using the custom sentiment lexicon, where the analysis is limited to cartels convicted after 2004. Significance level: ${ }^{a} p<0.01,{ }^{b} p<0.05,{ }^{c} p<0.10$. Clustered (by firm) standard error in parenthesis. †Controls: number of cartel members, cartel duration, dummy for observations with no data on cartel duration, dummy for recidivist firm, dummy indicating whether the firm received leniency, time trend, and firm market capitalisation (proxy for firm size). 
Table C.8: Regression analysis of percentage CAR (polar custom score weighted by the circulation of news)

\author{
CAR $[-1,1] \quad$ CAR $[-10,10] \quad$ CAR[-10,-1] CAR[1,10] CAR[-1,1] CAR[-10,10] CAR[-10,-1] CAR[1,10] \\ no controls \\ with controls $\dagger$
}

\begin{tabular}{|c|c|c|c|c|c|c|c|c|}
\hline \multirow[b]{2}{*}{ cons } & \multicolumn{8}{|c|}{ linear regression } \\
\hline & $\begin{array}{l}-0.595^{b} \\
(0.229)\end{array}$ & $\begin{array}{l}-2.072^{a} \\
(0.661)\end{array}$ & $\begin{array}{l}-1.110^{b} \\
(0.439)\end{array}$ & $\begin{array}{l}-0.728 \\
(0.442)\end{array}$ & $\begin{array}{l}-0.617 \\
(0.908)\end{array}$ & $\begin{array}{l}0.441 \\
(2.880)\end{array}$ & $\begin{array}{l}0.275 \\
(2.028)\end{array}$ & $\begin{array}{l}0.294 \\
(2.141)\end{array}$ \\
\hline $\mathrm{E}$ & $\begin{array}{l}-0.172 \\
(0.209)\end{array}$ & $\begin{array}{l}1.078^{b} \\
(0.528)\end{array}$ & $\begin{array}{l}0.656 \\
(0.421)\end{array}$ & $\begin{array}{l}0.607 \\
(0.408)\end{array}$ & $\begin{array}{l}-0.245 \\
(0.232)\end{array}$ & $\begin{array}{l}1.343^{b} \\
(0.618)\end{array}$ & $\begin{array}{l}0.990^{b} \\
(0.479)\end{array}$ & $\begin{array}{l}0.557 \\
(0.468)\end{array}$ \\
\hline $\mathrm{F}$ & $\begin{array}{l}-1.038^{a} \\
(0.332)\end{array}$ & $\begin{array}{l}-0.986 \\
(0.845)\end{array}$ & $\begin{array}{l}-0.399 \\
(0.591)\end{array}$ & $\begin{array}{l}-0.036 \\
(0.388)\end{array}$ & $\begin{array}{l}-0.994^{a} \\
(0.333)\end{array}$ & $\begin{array}{l}-0.762 \\
(0.919)\end{array}$ & $\begin{array}{l}-0.417 \\
(0.643)\end{array}$ & $\begin{array}{l}0.186 \\
(0.459)\end{array}$ \\
\hline S & $\begin{array}{l}0.154 \\
(0.248)\end{array}$ & $\begin{array}{l}2.462^{a} \\
(0.830)\end{array}$ & $\begin{array}{l}1.814^{a} \\
(0.625)\end{array}$ & $\begin{array}{l}0.422 \\
(0.572)\end{array}$ & $\begin{array}{l}0.167 \\
(0.271)\end{array}$ & $\begin{array}{l}2.150^{b} \\
(0.892)\end{array}$ & $\begin{array}{l}1.585^{b} \\
(0.681)\end{array}$ & $\begin{array}{l}0.323 \\
(0.581)\end{array}$ \\
\hline \multirow{3}{*}{$\begin{array}{l}\text { Joint } F \\
\mathrm{R}^{2}\end{array}$} & $3.742^{b}$ & $3.947^{a}$ & $3.298^{b}$ & 0.773 & $2.861^{a}$ & $4.055^{a}$ & $4.401^{a}$ & $1.644^{c}$ \\
\hline & 0.068 & 0.058 & 0.055 & 0.007 & 0.073 & 0.074 & 0.067 & 0.028 \\
\hline & \multicolumn{8}{|c|}{ linear regression with interactions } \\
\hline cons & $\begin{array}{l}-0.525^{b} \\
(0.249)\end{array}$ & $\begin{array}{l}-2.452^{a} \\
(0.686)\end{array}$ & $\begin{array}{l}-1.332^{a} \\
(0.479)\end{array}$ & $\begin{array}{l}-0.894^{c} \\
(0.456)\end{array}$ & $\begin{array}{l}-0.531 \\
(0.897)\end{array}$ & $\begin{array}{l}0.973 \\
(2.950)\end{array}$ & $\begin{array}{l}0.831 \\
(2.013)\end{array}$ & $\begin{array}{l}0.086 \\
(2.172)\end{array}$ \\
\hline $\mathrm{E}$ & $\begin{array}{l}-0.105 \\
(0.273)\end{array}$ & $\begin{array}{l}0.282 \\
(0.630)\end{array}$ & $\begin{array}{l}0.133 \\
(0.444)\end{array}$ & $\begin{array}{l}0.391 \\
(0.469)\end{array}$ & $\begin{array}{l}-0.164 \\
(0.307)\end{array}$ & $\begin{array}{l}0.491 \\
(0.710)\end{array}$ & $\begin{array}{l}0.569 \\
(0.478)\end{array}$ & $\begin{array}{l}0.155 \\
(0.538)\end{array}$ \\
\hline $\mathrm{F}$ & $\begin{array}{l}-1.001^{b} \\
(0.396)\end{array}$ & $\begin{array}{l}-1.439^{c} \\
(0.768)\end{array}$ & $\begin{array}{l}-0.713 \\
(0.506)\end{array}$ & $\begin{array}{l}-0.125 \\
(0.516)\end{array}$ & $\begin{array}{l}-0.952^{b} \\
(0.407)\end{array}$ & $\begin{array}{l}-1.222 \\
(0.819)\end{array}$ & $\begin{array}{l}-0.722 \\
(0.540)\end{array}$ & $\begin{array}{l}0.080 \\
(0.577)\end{array}$ \\
\hline $\mathrm{S}$ & $\begin{array}{l}0.249 \\
(0.261)\end{array}$ & $\begin{array}{l}2.093^{b} \\
(0.819)\end{array}$ & $\begin{array}{l}1.651^{a} \\
(0.599)\end{array}$ & $\begin{array}{l}0.180 \\
(0.544)\end{array}$ & $\begin{array}{l}0.239 \\
(0.283)\end{array}$ & $\begin{array}{l}1.890^{b} \\
(0.868)\end{array}$ & $\begin{array}{l}1.519^{b} \\
(0.654)\end{array}$ & $\begin{array}{l}0.095 \\
(0.561)\end{array}$ \\
\hline $\mathrm{EF}$ & $\begin{array}{l}0.247 \\
(0.625)\end{array}$ & $\begin{array}{l}-1.163 \\
(1.225)\end{array}$ & $\begin{array}{l}-1.210 \\
0.740)\end{array}$ & 0.207 & 0.245 & $\begin{array}{l}-1.000) \\
-(1216)\end{array}$ & $\begin{array}{l}(0.034) \\
-1.241\end{array}$ & $\begin{array}{l}(0.081) \\
0.081 \\
(0.890)\end{array}$ \\
\hline ES & 0.130 & $-1.239^{c}$ & $-0.767^{c}$ & -0.427 & 0.097 & $-1.284^{c}$ & $\begin{array}{l}(0.161) \\
-0.634\end{array}$ & $\begin{array}{l}(0.892) \\
-0.601\end{array}$ \\
\hline & $(0.242)$ & $(0.651)$ & $(0.418)$ & $(0.383)$ & $(0.267)$ & $(0.721)$ & $(0.473)$ & $(0.419)$ \\
\hline FS & $\begin{array}{l}0.517 \\
(0494)\end{array}$ & 0.084 & $\begin{array}{l}0.644 \\
(0.574)\end{array}$ & $\begin{array}{l}-1.024 \\
(0.773)\end{array}$ & 0.537 & $\begin{array}{l}0.152 \\
(1.112)\end{array}$ & $\begin{array}{l}0.730 \\
(0606)\end{array}$ & $\begin{array}{l}-1.045 \\
(0.737)\end{array}$ \\
\hline EFS & $\begin{array}{l}-0.062 \\
(0.461)\end{array}$ & $\begin{array}{l}-2.444 \\
(1.577)\end{array}$ & $\begin{array}{l}-1.572^{c} \\
(0.858)\end{array}$ & $\begin{array}{l}-0.506 \\
(0.830)\end{array}$ & $\begin{array}{l}-0.027 \\
(0.480)\end{array}$ & $\begin{array}{l}-2.511 \\
(1.539)\end{array}$ & $\begin{array}{l}-1.606^{c} \\
(0.884)\end{array}$ & $\begin{array}{l}-0.536 \\
(0.812)\end{array}$ \\
\hline Joint F & $1.857^{c}$ & $4.218^{a}$ & $4.626^{a}$ & 1.181 & $2.154^{b}$ & $4.806^{a}$ & $5.538^{a}$ & $1.682^{c}$ \\
\hline $\mathrm{R}^{2}$ & 0.077 & 0.080 & 0.086 & 0.022 & 0.082 & 0.097 & 0.099 & 0.043 \\
\hline Obs & 287 & 287 & 287 & 287 & 287 & 287 & 287 & 287 \\
\hline
\end{tabular}

Notes: This table shows OLS regressions on the cumulative abnormal rate of return, using the custom sentiment lexicon weighted by circulation of news. Significance level: ${ }^{a} p<0.01,{ }^{b} p<0.05,{ }^{c} p<0.10$. Clustered (by firm) standard error in parenthesis. $\dagger$ Controls: number of cartel members, cartel duration, dummy for observations with no data on cartel duration, dummy for recidivist firm, dummy indicating whether the firm received leniency, time trend, and firm market capitalisation (proxy for firm size). 
Table C.9: Regression analysis of percentage CAR (polar custom score) limited to cartels with $\leq 9$ members

CAR $[-1,1] \quad$ CAR $[-10,10] \quad$ CAR[-10,-1] CAR[1,10]

no controls
CAR[-1,1] CAR[-10,10] CAR[-10,-1] CAR[1,10] with controls $\dagger$

\begin{tabular}{|c|c|c|c|c|c|c|c|c|}
\hline \multirow[b]{2}{*}{ cons } & \multicolumn{8}{|c|}{ linear regression } \\
\hline & $\begin{array}{c}-0.659^{b} \\
(0.288)\end{array}$ & $\begin{array}{l}-2.344^{a} \\
(0.804)\end{array}$ & $\begin{array}{l}-1.193^{c} \\
(0.612)\end{array}$ & $\begin{array}{l}-0.925 \\
(0.570)\end{array}$ & $\begin{array}{l}-3.023 \\
(1.918)\end{array}$ & $\begin{array}{l}-2.174 \\
(3.924)\end{array}$ & $\begin{array}{l}1.829 \\
(3.755)\end{array}$ & $\begin{array}{l}-3.432 \\
(3.507)\end{array}$ \\
\hline $\mathrm{E}$ & $\begin{array}{l}0.451 \\
(0.331)\end{array}$ & $\begin{array}{l}2.776^{a} \\
(0.886)\end{array}$ & $\begin{array}{l}0.910 \\
(0.617)\end{array}$ & $\begin{array}{l}1.834^{a} \\
(0.593)\end{array}$ & $\begin{array}{l}0.202 \\
(0.418)\end{array}$ & $\begin{array}{l}2.604^{b} \\
(1.045)\end{array}$ & $\begin{array}{l}1.254 \\
(0.823)\end{array}$ & $\begin{array}{l}1.365^{c} \\
(0.724)\end{array}$ \\
\hline $\mathrm{F}$ & $\begin{array}{c}-0.798^{a} \\
(0.296)\end{array}$ & $\begin{array}{l}-0.800 \\
(0.989)\end{array}$ & $\begin{array}{l}-0.746 \\
(0.710)\end{array}$ & $\begin{array}{l}0.359 \\
(0.540)\end{array}$ & $\begin{array}{l}-0.844^{b} \\
(0.325)\end{array}$ & $\begin{array}{l}-0.527 \\
(1.251)\end{array}$ & $\begin{array}{l}-0.550 \\
(0.897)\end{array}$ & $\begin{array}{l}0.448 \\
(0.658)\end{array}$ \\
\hline $\mathrm{S}$ & $\begin{array}{l}-0.038 \\
(0.451)\end{array}$ & $\begin{array}{l}2.081 \\
(1.449)\end{array}$ & $\begin{array}{l}2.671^{c} \\
(1.447)\end{array}$ & $\begin{array}{l}-0.635 \\
(0.927)\end{array}$ & $\begin{array}{l}0.067 \\
(0.477)\end{array}$ & $\begin{array}{l}1.912 \\
(1.476)\end{array}$ & $\begin{array}{l}2.526^{c} \\
(1.372)\end{array}$ & $\begin{array}{l}-0.660 \\
(1.005)\end{array}$ \\
\hline \multirow{3}{*}{$\begin{array}{l}\text { Joint } \mathrm{F} \\
\mathrm{R}^{2}\end{array}$} & $3.117^{b}$ & $5.132^{a}$ & $2.260^{c}$ & 3.335 & $4.372^{a}$ & $7.932^{a}$ & $14.211^{a}$ & $1.935^{c}$ \\
\hline & 0.079 & 0.093 & 0.073 & 0.062 & 0.121 & 0.127 & 0.098 & 0.076 \\
\hline & \multicolumn{8}{|c|}{ linear regression with interactions } \\
\hline cons & $\begin{array}{l}-0.631^{b} \\
(0.295)\end{array}$ & $\begin{array}{l}-2.544^{a} \\
(0.851)\end{array}$ & $\begin{array}{c}-1.298^{b} \\
(0.644)\end{array}$ & $\begin{array}{l}-1.046^{c} \\
(0.587)\end{array}$ & $\begin{array}{l}-3.703^{c} \\
(1.886)\end{array}$ & $\begin{array}{l}-0.676 \\
(4.515)\end{array}$ & $\begin{array}{l}3.655 \\
(4.138)\end{array}$ & $\begin{array}{l}-3.430 \\
(3.767)\end{array}$ \\
\hline \multirow[t]{2}{*}{$\mathrm{E}$} & 0.617 & 1.262 & -0.215 & $1.384^{c}$ & 0.292 & 1.304 & 0.317 & 0.983 \\
\hline & $(0.411)$ & $(1.089)$ & $(0.665)$ & $(0.774)$ & $(0.482)$ & $(1.358)$ & $(0.866)$ & $(0.945)$ \\
\hline $\mathrm{F}$ & $\begin{array}{l}-0.924^{a} \\
(0.246)\end{array}$ & $\begin{array}{l}-0.975 \\
(0.702)\end{array}$ & $\begin{array}{l}-0.576 \\
(0.402)\end{array}$ & $\begin{array}{l}0.055 \\
(0.501)\end{array}$ & $\begin{array}{l}-1.018^{a} \\
(0.322)\end{array}$ & $\begin{array}{l}-0.580 \\
(0.781)\end{array}$ & $\begin{array}{l}-0.215 \\
(0.521)\end{array}$ & $\begin{array}{l}0.113 \\
(0.565)\end{array}$ \\
\hline $\mathrm{S}$ & $\begin{array}{l}-0.019 \\
(0.453)\end{array}$ & $\begin{array}{l}2.185 \\
(1.330)\end{array}$ & $\begin{array}{l}2.753^{b} \\
(1.387)\end{array}$ & $\begin{array}{l}-0.644 \\
(0.927)\end{array}$ & $\begin{array}{l}0.135 \\
(0.475)\end{array}$ & $\begin{array}{l}2.030 \\
(1.320)\end{array}$ & $\begin{array}{l}2.542^{c} \\
(1.289)\end{array}$ & $\begin{array}{l}-0.616 \\
(0.979)\end{array}$ \\
\hline EF & $\begin{array}{l}0.954 \\
(0.954)\end{array}$ & $\begin{array}{l}-4.980^{c} \\
(2.571)\end{array}$ & $\begin{array}{l}-3.746^{b} \\
(1.520)\end{array}$ & $\begin{array}{l}-1.916 \\
(1.640)\end{array}$ & $\begin{array}{l}0.996 \\
(1.037)\end{array}$ & $\begin{array}{l}-5.558^{c} \\
(2.928)\end{array}$ & $\begin{array}{l}-4.292^{b} \\
(1.918)\end{array}$ & $\begin{array}{l}-1.887 \\
(1.825)\end{array}$ \\
\hline ES & $\begin{array}{l}0.418 \\
(0.531)\end{array}$ & $\begin{array}{l}-4.155^{a} \\
(1.581)\end{array}$ & $\begin{array}{l}-2.773^{b} \\
(1.124)\end{array}$ & $\begin{array}{l}-1.501 \\
(1.071)\end{array}$ & $\begin{array}{l}0.664 \\
(0.526)\end{array}$ & $\begin{array}{l}-4.061^{b} \\
(1.663)\end{array}$ & $\begin{array}{l}-2.958^{b} \\
(1.184)\end{array}$ & $\begin{array}{l}-1.363 \\
(1.121)\end{array}$ \\
\hline FS & $\begin{array}{l}-0.393 \\
(0.457)\end{array}$ & $\begin{array}{l}-0.094 \\
(0.970)\end{array}$ & $\begin{array}{l}0.839 \\
(0.527)\end{array}$ & $\begin{array}{l}-0.831 \\
(0.824)\end{array}$ & $\begin{array}{l}-0.444 \\
(0.511)\end{array}$ & $\begin{array}{l}0.214 \\
(1.002)\end{array}$ & $\begin{array}{l}1.195^{b} \\
(0.574)\end{array}$ & $\begin{array}{c}-0.904 \\
(0.842)\end{array}$ \\
\hline EFS & $\begin{array}{l}0.363 \\
(0.986)\end{array}$ & $\begin{array}{l}-4.830^{c} \\
(2.802)\end{array}$ & $\begin{array}{l}-3.797^{b} \\
(1.501)\end{array}$ & $\begin{array}{l}-0.990 \\
(1.940)\end{array}$ & $\begin{array}{l}0.288 \\
(1.032)\end{array}$ & $\begin{array}{l}-5.241^{c} \\
(2.970)\end{array}$ & $\begin{array}{l}-4.155^{b} \\
(1.733)\end{array}$ & $\begin{array}{l}-0.951 \\
(2.021)\end{array}$ \\
\hline Joint F & $2.488^{b}$ & $3.679^{a}$ & $3.468^{a}$ & $3.319^{a}$ & $3.243^{a}$ & $6.179^{a}$ & $12.979^{a}$ & $1.911^{b}$ \\
\hline $\mathrm{R}^{2}$ & 0.098 & 0.165 & 0.126 & 0.091 & 0.146 & 0.199 & 0.163 & 0.102 \\
\hline Obs & 131 & 131 & 131 & 131 & 131 & 131 & 131 & 131 \\
\hline
\end{tabular}


Table C.10: Regression analysis of percentage CAR (polar custom score) limited to cartels with $>9$ members

CAR[-1,1] CAR[-10,10] CAR[-10,-1] CAR[1,10] CAR[-1,1] CAR[-10,10] CAR[-10,-1] CAR[1,10]

no controls

with controls $\uparrow$

\begin{tabular}{|c|c|c|c|c|c|c|c|c|}
\hline \multirow[b]{2}{*}{ cons } & \multicolumn{8}{|c|}{ linear regression } \\
\hline & $\begin{array}{l}-0.618 \\
(0.450)\end{array}$ & $\begin{array}{c}-2.520^{b} \\
(1.074)\end{array}$ & $\begin{array}{l}-0.868 \\
(0.580)\end{array}$ & $\begin{array}{l}-1.290^{c} \\
(0.693)\end{array}$ & $\begin{array}{l}0.317 \\
(1.272)\end{array}$ & $\begin{array}{l}4.567 \\
(4.528)\end{array}$ & $\begin{array}{l}-1.175 \\
(2.829)\end{array}$ & $\begin{array}{l}5.623^{c} \\
(2.962)\end{array}$ \\
\hline $\mathrm{E}$ & $\begin{array}{c}-0.567^{b} \\
(0.277)\end{array}$ & $\begin{array}{l}-0.105 \\
(0.723)\end{array}$ & $\begin{array}{l}0.215 \\
(0.472)\end{array}$ & $\begin{array}{l}-0.012 \\
(0.576)\end{array}$ & $\begin{array}{l}-0.525^{c} \\
(0.276)\end{array}$ & $\begin{array}{l}0.325 \\
(0.828)\end{array}$ & $\begin{array}{l}0.535 \\
(0.525)\end{array}$ & $\begin{array}{l}0.053 \\
(0.604)\end{array}$ \\
\hline $\mathrm{F}$ & $\begin{array}{l}-1.842^{b} \\
(0.868)\end{array}$ & $\begin{array}{l}-1.757 \\
(1.749)\end{array}$ & $\begin{array}{l}-0.532 \\
(0.845)\end{array}$ & $\begin{array}{l}0.036 \\
(0.863)\end{array}$ & $\begin{array}{c}-1.891^{b} \\
(0.894)\end{array}$ & $\begin{array}{l}-2.272 \\
(1.810)\end{array}$ & $\begin{array}{l}-1.233 \\
(0.855)\end{array}$ & $\begin{array}{l}0.256 \\
(0.983)\end{array}$ \\
\hline S & $\begin{array}{l}0.204 \\
(0.354)\end{array}$ & $\begin{array}{l}0.706 \\
(1.077)\end{array}$ & $\begin{array}{l}0.712 \\
(0.511)\end{array}$ & $\begin{array}{l}-0.331 \\
(0.698)\end{array}$ & $\begin{array}{l}0.256 \\
(0.460)\end{array}$ & $\begin{array}{l}0.715 \\
(1.294)\end{array}$ & $\begin{array}{l}0.148 \\
(0.613)\end{array}$ & $\begin{array}{l}0.162 \\
(0.807)\end{array}$ \\
\hline \multirow{3}{*}{$\begin{array}{l}\text { Joint F } \\
\mathrm{R}^{2}\end{array}$} & 2.897 & 0.549 & 0.815 & 0.092 & 1.567 & 0.626 & 0.868 & 1.134 \\
\hline & 0.109 & 0.019 & 0.017 & 0.002 & 0.112 & 0.061 & 0.084 & 0.065 \\
\hline & \multicolumn{8}{|c|}{ linear regression with interactions } \\
\hline cons & $\begin{array}{l}-0.875 \\
(0.562)\end{array}$ & $\begin{array}{l}-2.475^{b} \\
(1.177)\end{array}$ & $\begin{array}{l}-0.275 \\
(0.684)\end{array}$ & $\begin{array}{l}-1.513^{c} \\
(0.818)\end{array}$ & $\begin{array}{l}-0.009 \\
(1.384)\end{array}$ & $\begin{array}{l}4.499 \\
(4.609)\end{array}$ & $\begin{array}{l}-0.571 \\
(2.813)\end{array}$ & $\begin{array}{l}5.377^{c} \\
(3.088)\end{array}$ \\
\hline $\mathrm{E}$ & $\begin{array}{l}-0.804^{c} \\
(0.484)\end{array}$ & $\begin{array}{l}0.319 \\
(1.080)\end{array}$ & $\begin{array}{l}1.324^{c} \\
(0.732)\end{array}$ & $\begin{array}{l}-0.333 \\
(0.866)\end{array}$ & $\begin{array}{l}-0.779 \\
(0.524)\end{array}$ & $\begin{array}{l}0.826 \\
(1.372)\end{array}$ & $\begin{array}{l}1.924^{b} \\
(0.819)\end{array}$ & $\begin{array}{l}-0.519 \\
(1.035)\end{array}$ \\
\hline $\mathrm{F}$ & $\begin{array}{c}-2.607^{b} \\
(1.076)\end{array}$ & $\begin{array}{l}-2.203 \\
(2.030)\end{array}$ & $\begin{array}{l}0.391 \\
(1.141)\end{array}$ & $\begin{array}{l}-0.251 \\
(1.181)\end{array}$ & $\begin{array}{l}-2.732^{b} \\
(1.086)\end{array}$ & $\begin{array}{l}-3.071 \\
(2.037)\end{array}$ & $\begin{array}{l}-0.630 \\
(1.120)\end{array}$ & $\begin{array}{l}0.023 \\
(1.384)\end{array}$ \\
\hline S & $\begin{array}{l}0.094 \\
(0.634)\end{array}$ & $\begin{array}{l}1.432 \\
(1.373)\end{array}$ & $\begin{array}{l}1.968^{b} \\
(0.847)\end{array}$ & $\begin{array}{l}-0.625 \\
(0.955)\end{array}$ & $\begin{array}{l}0.040 \\
(0.725)\end{array}$ & $\begin{array}{l}1.428 \\
(1.759)\end{array}$ & $\begin{array}{l}1.643^{c} \\
(0.953)\end{array}$ & $\begin{array}{l}-0.285 \\
(1.179)\end{array}$ \\
\hline $\mathrm{EF}$ & $\begin{array}{l}-0.654 \\
(1.170)\end{array}$ & $\begin{array}{l}2.982 \\
(2.370)\end{array}$ & $\begin{array}{l}3.324^{b} \\
(1.369)\end{array}$ & $\begin{array}{l}1.466 \\
(1.894)\end{array}$ & $\begin{array}{l}-0.705 \\
(1.106)\end{array}$ & $\begin{array}{l}2.782 \\
(2.562)\end{array}$ & $\begin{array}{l}3.115^{b} \\
(1.367)\end{array}$ & $\begin{array}{l}1.582 \\
(2.104)\end{array}$ \\
\hline ES & $\begin{array}{l}-0.440 \\
(0.660)\end{array}$ & $\begin{array}{l}0.377 \\
(1.307)\end{array}$ & $\begin{array}{l}1.657^{c} \\
(0.895)\end{array}$ & $\begin{array}{l}-0.738 \\
(0.991)\end{array}$ & $\begin{array}{l}-0.480 \\
(0.668)\end{array}$ & $\begin{array}{l}0.480 \\
(1.534)\end{array}$ & $\begin{array}{l}2.037^{b} \\
(0.964)\end{array}$ & $\begin{array}{l}-1.055 \\
(1.155)\end{array}$ \\
\hline FS & $\begin{array}{l}0.855 \\
(1.547)\end{array}$ & $\begin{array}{l}4.256 \\
(2.975)\end{array}$ & $\begin{array}{l}3.506^{c} \\
(1.818)\end{array}$ & $\begin{array}{l}0.822 \\
(1.858)\end{array}$ & $\begin{array}{l}0.862 \\
(1.543)\end{array}$ & $\begin{array}{l}4.585 \\
(2.925)\end{array}$ & $\begin{array}{l}3.749^{b} \\
(1.699)\end{array}$ & $\begin{array}{l}0.950 \\
(2.018)\end{array}$ \\
\hline EFS & $\begin{array}{l}-1.096 \\
(1.704)\end{array}$ & $\begin{array}{l}0.733 \\
(3.265)\end{array}$ & $\begin{array}{l}3.845^{c} \\
(2.001)\end{array}$ & $\begin{array}{l}-0.895 \\
(2.391)\end{array}$ & $\begin{array}{l}-1.211 \\
(1.638)\end{array}$ & $\begin{array}{l}0.387 \\
(3.619)\end{array}$ & $\begin{array}{l}3.427 \\
(2.075)\end{array}$ & $\begin{array}{l}-0.677 \\
(2.734)\end{array}$ \\
\hline Joint $\mathrm{F}$ & $2.536^{b}$ & 1.358 & 1.660 & $2.940^{a}$ & $1.778^{c}$ & 1.282 & 1.407 & $1.968^{b}$ \\
\hline $\mathrm{R}^{2}$ & 0.145 & 0.056 & 0.053 & 0.035 & 0.150 & 0.105 & 0.132 & 0.103 \\
\hline Obs & 120 & 120 & 120 & 120 & 120 & 120 & 120 & 120 \\
\hline
\end{tabular}


Table C.11: Regression analysis of percentage CAR (polar custom score) excluding bid-rigging cartels CAR[-1,1] CAR[-10,10] CAR[-10,-1] CAR[1,10]

CAR $[-1,1] \quad$ CAR $[-10,10] \quad$ CAR $[-10,-1] \quad$ CAR $[1,10]$ no controls with controls $\dagger$

\begin{tabular}{|c|c|c|c|c|c|c|c|c|}
\hline \multirow[b]{2}{*}{ cons } & \multicolumn{8}{|c|}{ linear regression } \\
\hline & $\begin{array}{l}-0.680^{c} \\
(0.404)\end{array}$ & $\begin{array}{c}-1.970^{b} \\
(0.766)\end{array}$ & $\begin{array}{c}-0.724 \\
(0.532)\end{array}$ & $\begin{array}{l}-0.888 \\
(0.548)\end{array}$ & $\begin{array}{l}-0.909 \\
(1.072)\end{array}$ & $\begin{array}{l}0.501 \\
(2.998)\end{array}$ & $\begin{array}{l}-1.687 \\
(2.012)\end{array}$ & $\begin{array}{l}2.565 \\
(2.223)\end{array}$ \\
\hline $\mathrm{E}$ & -0.218 & 0.505 & 0.188 & 0.514 & -0.322 & 0.760 & 0.380 & 0.616 \\
\hline & $(0.240)$ & $(0.490)$ & $(0.373)$ & $(0.399)$ & $(0.238)$ & $(0.601)$ & $(0.414)$ & $(0.420)$ \\
\hline $\mathrm{F}$ & $-1.065^{a}$ & -1.511 & -1.077 & $\begin{array}{l}0.273 \\
(0.523)\end{array}$ & $-1.017^{b}$ & $\begin{array}{l}-1.499 \\
(0.927)\end{array}$ & $-1.267^{b}$ & $\begin{array}{l}0.452 \\
(0.608)\end{array}$ \\
\hline S & $\begin{array}{l}0.030 \\
(0.488)\end{array}$ & $\begin{array}{l}1.185 \\
(1.103)\end{array}$ & $\begin{array}{l}1.103^{c} \\
(0.611)\end{array}$ & $\begin{array}{l}-0.086 \\
(0.800)\end{array}$ & $\begin{array}{l}0.110 \\
(0.485)\end{array}$ & $\begin{array}{l}1.240 \\
(1.162)\end{array}$ & $\begin{array}{l}1.013 \\
(0.655)\end{array}$ & $\begin{array}{l}0.004 \\
(0.812)\end{array}$ \\
\hline \multirow{3}{*}{$\begin{array}{l}\text { Joint } \mathrm{F} \\
\mathrm{R}^{2}\end{array}$} & $2.592^{c}$ & 1.724 & 2.093 & 0.634 & $3.348^{a}$ & $1.976^{b}$ & $3.672^{a}$ & 1.048 \\
\hline & 0.072 & 0.038 & 0.046 & 0.008 & 0.091 & 0.047 & 0.105 & 0.040 \\
\hline & \multicolumn{8}{|c|}{ linear regression with interactions } \\
\hline cons & $\begin{array}{l}-0.712^{c} \\
(0.409)\end{array}$ & $\begin{array}{c}-1.897^{b} \\
(0.770)\end{array}$ & $\begin{array}{l}-0.648 \\
(0.530)\end{array}$ & $\begin{array}{l}-0.871 \\
(0.555)\end{array}$ & $\begin{array}{l}-0.957 \\
(1.102)\end{array}$ & $\begin{array}{l}0.644 \\
(3.048)\end{array}$ & $\begin{array}{l}-1.509 \\
(2.054)\end{array}$ & $\begin{array}{l}2.573 \\
(2.259)\end{array}$ \\
\hline $\mathrm{E}$ & $\begin{array}{l}-0.415 \\
(0.412)\end{array}$ & $\begin{array}{l}0.653 \\
(0.706)\end{array}$ & $\begin{array}{l}0.563 \\
(0.526)\end{array}$ & $\begin{array}{l}0.697 \\
(0.573)\end{array}$ & $\begin{array}{l}-0.563 \\
(0.429)\end{array}$ & $\begin{array}{l}0.948 \\
(0.779)\end{array}$ & $\begin{array}{l}0.898 \\
(0.550)\end{array}$ & $\begin{array}{l}0.690 \\
(0.602)\end{array}$ \\
\hline $\mathrm{F}$ & $\begin{array}{l}-1.218^{a} \\
(0.285)\end{array}$ & $\begin{array}{l}-1.052 \\
(0.653)\end{array}$ & $\begin{array}{l}-0.548 \\
(0.408)\end{array}$ & $\begin{array}{l}0.240 \\
(0.384)\end{array}$ & $\begin{array}{c}-1.166^{a} \\
(0.293)\end{array}$ & $\begin{array}{l}-1.021 \\
(0.647)\end{array}$ & $\begin{array}{c}-0.695^{b} \\
(0.326)\end{array}$ & $\begin{array}{l}0.386 \\
(0.463)\end{array}$ \\
\hline S & $\begin{array}{l}-0.048 \\
(0.498)\end{array}$ & $\begin{array}{l}1.368 \\
(1.099)\end{array}$ & $\begin{array}{l}1.307^{b} \\
(0.604)\end{array}$ & $\begin{array}{l}-0.060 \\
(0.815)\end{array}$ & $\begin{array}{l}0.042 \\
(0.497)\end{array}$ & $\begin{array}{l}1.390 \\
(1.185)\end{array}$ & $\begin{array}{l}1.166^{c} \\
(0.639)\end{array}$ & $\begin{array}{l}0.069 \\
(0.843)\end{array}$ \\
\hline $\mathrm{EF}$ & $\begin{array}{l}-0.630 \\
(0.884)\end{array}$ & $\begin{array}{l}0.387 \\
(1.504)\end{array}$ & $\begin{array}{l}0.762 \\
(1.166)\end{array}$ & $\begin{array}{l}0.837 \\
(1.095)\end{array}$ & $\begin{array}{l}-0.696 \\
(0.909)\end{array}$ & $\begin{array}{l}0.398 \\
(1.496)\end{array}$ & $\begin{array}{l}0.889 \\
(1.166)\end{array}$ & $\begin{array}{l}0.832 \\
(1.163)\end{array}$ \\
\hline $\mathrm{ES}$ & $\begin{array}{l}-0.239 \\
(0.587)\end{array}$ & $\begin{array}{l}0.133 \\
(0.904)\end{array}$ & $\begin{array}{l}0.551 \\
(0.674)\end{array}$ & $\begin{array}{l}0.154 \\
(0.779)\end{array}$ & $\begin{array}{l}-0.326 \\
(0.606)\end{array}$ & $\begin{array}{l}0.117 \\
(0.887)\end{array}$ & $\begin{array}{l}0.728 \\
(0.679)\end{array}$ & $\begin{array}{c}-0.023 \\
(0.790)\end{array}$ \\
\hline FS & $\begin{array}{l}-0.466 \\
(0.425)\end{array}$ & $\begin{array}{l}1.479^{c} \\
(0.800)\end{array}$ & $\begin{array}{l}1.626^{a} \\
(0.548)\end{array}$ & $\begin{array}{l}-0.143 \\
(0.724)\end{array}$ & $\begin{array}{l}-0.455 \\
(0.451)\end{array}$ & $\begin{array}{l}1.527^{c} \\
(0.864)\end{array}$ & $\begin{array}{l}1.823^{a} \\
(0.447)\end{array}$ & $\begin{array}{c}-0.324 \\
(0.770)\end{array}$ \\
\hline EFS & $\begin{array}{l}-1.233 \\
(1.461)\end{array}$ & $\begin{array}{l}1.143 \\
(2.263)\end{array}$ & $\begin{array}{l}2.133 \\
(1.684)\end{array}$ & $\begin{array}{l}1.414 \\
(2.022)\end{array}$ & $\begin{array}{l}-1.280 \\
(1.517)\end{array}$ & $\begin{array}{l}1.188 \\
(2.244)\end{array}$ & $\begin{array}{l}1.993 \\
(1.685)\end{array}$ & $\begin{array}{l}1.702 \\
(1.999)\end{array}$ \\
\hline Joint $\mathrm{F}$ & $5.898^{a}$ & 1.175 & $2.319^{b}$ & 0.485 & 5.259 & 1.669 & 4.389 & 0.869 \\
\hline $\mathrm{R}^{2}$ & 0.080 & 0.047 & 0.075 & 0.011 & 0.098 & 0.057 & 0.136 & 0.045 \\
\hline Obs & 183 & 183 & 183 & 183 & 183 & 183 & 183 & 183 \\
\hline
\end{tabular}


Table C.12: Regression analysis of percentage CAR (polar custom score) excluding cartels with a ring-leader

\author{
CAR[-1,1] CAR[-10,10] CAR[-10,-1] CAR[1,10] CAR[-1,1] CAR[-10,10] CAR[-10,-1] CAR[1,10]
}

no controls

with controls $\dagger$

\begin{tabular}{|c|c|c|c|c|c|c|c|c|}
\hline \multirow[b]{2}{*}{ cons } & \multicolumn{8}{|c|}{ linear regression } \\
\hline & $\begin{array}{l}-0.436 \\
(0.430)\end{array}$ & $\begin{array}{l}-1.561^{c} \\
(0.918)\end{array}$ & $\begin{array}{l}-0.616 \\
(0.624)\end{array}$ & $\begin{array}{l}-0.752 \\
(0.610)\end{array}$ & $\begin{array}{l}0.020 \\
(1.806)\end{array}$ & $\begin{array}{l}3.181 \\
(5.969)\end{array}$ & $\begin{array}{l}1.122 \\
(3.204)\end{array}$ & $\begin{array}{l}2.705 \\
(3.898)\end{array}$ \\
\hline $\mathrm{E}$ & $\begin{array}{l}0.234 \\
(0.480)\end{array}$ & $\begin{array}{l}0.188 \\
(1.011)\end{array}$ & $\begin{array}{l}-1.108 \\
(0.681)\end{array}$ & $\begin{array}{l}1.235 \\
(0.758)\end{array}$ & $\begin{array}{l}0.349 \\
(0.583)\end{array}$ & $\begin{array}{l}1.501 \\
(1.587)\end{array}$ & $\begin{array}{l}-0.477 \\
(0.843)\end{array}$ & $\begin{array}{l}1.723 \\
(1.137)\end{array}$ \\
\hline $\mathrm{F}$ & $\begin{array}{l}-1.030^{b} \\
(0.401)\end{array}$ & $\begin{array}{l}-1.728^{b} \\
(0.813)\end{array}$ & $\begin{array}{l}-1.050^{c} \\
(0.582)\end{array}$ & $\begin{array}{l}-0.221 \\
(0.366)\end{array}$ & $\begin{array}{l}-0.846^{b} \\
(0.378)\end{array}$ & $\begin{array}{l}-1.625^{c} \\
(0.905)\end{array}$ & $\begin{array}{l}-1.238^{b} \\
(0.604)\end{array}$ & $\begin{array}{l}-0.066 \\
(0.454)\end{array}$ \\
\hline S & $\begin{array}{l}0.167 \\
(0.696)\end{array}$ & $\begin{array}{l}2.087 \\
(1.734)\end{array}$ & $\begin{array}{l}1.794^{c} \\
(0.908)\end{array}$ & $\begin{array}{l}0.312 \\
(1.182)\end{array}$ & $\begin{array}{l}0.212 \\
(0.630)\end{array}$ & $\begin{array}{l}1.834 \\
(1.761)\end{array}$ & $\begin{array}{l}1.434 \\
(0.910)\end{array}$ & $\begin{array}{l}0.400 \\
(1.170)\end{array}$ \\
\hline \multirow{3}{*}{$\begin{array}{l}\text { Joint } \mathrm{F} \\
\mathrm{R}^{2}\end{array}$} & $2.357^{c}$ & $2.141^{c}$ & $2.989^{b}$ & 1.296 & $2.423^{b}$ & $3.477^{a}$ & $7.701^{a}$ & 1.008 \\
\hline & 0.089 & 0.052 & 0.070 & 0.019 & 0.122 & 0.079 & 0.104 & 0.051 \\
\hline & \multicolumn{8}{|c|}{ linear regression with interactions } \\
\hline cons & $\begin{array}{l}-0.456 \\
(0.428)\end{array}$ & $-1.720^{c}$ & $\begin{array}{l}-0.716 \\
(0.629)\end{array}$ & -0.814 & -0.163 & 3.710 & 1.317 & 2.887 \\
\hline $\mathrm{E}$ & $\begin{array}{l}0.016 \\
(0.556)\end{array}$ & $\begin{array}{l}-0.128 \\
(1.129)\end{array}$ & $\begin{array}{l}-1.249^{c} \\
(0.712)\end{array}$ & $\begin{array}{l}1.093 \\
(0.809)\end{array}$ & $\begin{array}{l}-0.030 \\
(0.635)\end{array}$ & $\begin{array}{l}1.211 \\
(1.769)\end{array}$ & $\begin{array}{l}-0.578 \\
(0.941)\end{array}$ & $\begin{array}{l}1.487 \\
(1.284)\end{array}$ \\
\hline $\mathrm{F}$ & $\begin{array}{l}-1.173^{a} \\
(0.318)\end{array}$ & $\begin{array}{l}-1.378^{b} \\
(0.591)\end{array}$ & $\begin{array}{l}-0.750^{b} \\
(0.335)\end{array}$ & $\begin{array}{l}-0.086 \\
(0.297)\end{array}$ & $\begin{array}{l}-1.014^{a} \\
(0.330)\end{array}$ & $\begin{array}{l}-1.141^{c} \\
(0.592)\end{array}$ & $\begin{array}{l}-0.835^{b} \\
(0.331)\end{array}$ & $\begin{array}{l}0.105 \\
(0345)\end{array}$ \\
\hline S & 0.122 & 1.916 & $1.598^{c}$ & $\begin{array}{l}0.325 \\
(1208)\end{array}$ & 0.147 & 1.634 & $\begin{array}{l}1.229 \\
(0.866)\end{array}$ & 0.400 \\
\hline $\mathrm{EF}$ & 0.132 & -0.912 & -0.189 & -0.651 & -0.165 & -1.437 & 0.155 & -1.224 \\
\hline & $(0.798)$ & (1.406) & $(0.855)$ & $(0.803)$ & $(0.912)$ & $(1.595)$ & $(0.914)$ & $(0.926)$ \\
\hline ES & $\begin{array}{l}-1.082 \\
(1.205)\end{array}$ & $\begin{array}{l}-3.776 \\
(2.554)\end{array}$ & $\begin{array}{l}-2.167 \\
(1.412)\end{array}$ & $\begin{array}{l}-1.724 \\
(2.070)\end{array}$ & $\begin{array}{l}-1.098 \\
(1.165)\end{array}$ & $\begin{array}{l}-3.895 \\
(2.690)\end{array}$ & $\begin{array}{l}-2.153 \\
(1.586)\end{array}$ & $\begin{array}{l}-2.169 \\
(2.253)\end{array}$ \\
\hline FS & $\begin{array}{l}-0.476 \\
(0.410)\end{array}$ & $\begin{array}{l}1.336^{c} \\
(0.787)\end{array}$ & $\begin{array}{l}1.470^{a} \\
(0.465)\end{array}$ & $\begin{array}{l}0.194 \\
(0.439)\end{array}$ & $\begin{array}{l}-0.436 \\
(0.445)\end{array}$ & $\begin{array}{l}1.594^{c} \\
(0.836)\end{array}$ & $\begin{array}{l}1.667^{a} \\
(0.440)\end{array}$ & $\begin{array}{l}0.193 \\
(0.474)\end{array}$ \\
\hline EFS & $\begin{array}{l}-1.179 \\
(1.598)\end{array}$ & $\begin{array}{l}4.109^{c} \\
(2.463)\end{array}$ & $\begin{array}{l}2.212 \\
(1.570)\end{array}$ & $\begin{array}{l}2.480^{b} \\
(1.226)\end{array}$ & $\begin{array}{l}-1.202 \\
(1.668)\end{array}$ & $\begin{array}{l}4.193 \\
(2.618)\end{array}$ & $\begin{array}{l}2.325 \\
(1.610)\end{array}$ & $\begin{array}{l}2.447^{c} \\
(1.351)\end{array}$ \\
\hline Joint F & $3.213^{a}$ & $4.988^{a}$ & $5.929^{a}$ & $2.074^{c}$ & $2.299^{a}$ & $5.022^{a}$ & $11.527^{a}$ & $1.758^{c}$ \\
\hline $\mathrm{R}^{2}$ & 0.108 & 0.092 & 0.116 & 0.044 & 0.134 & 0.129 & 0.152 & 0.085 \\
\hline Obs & 138 & 138 & 138 & 138 & 138 & 138 & 138 & 138 \\
\hline
\end{tabular}




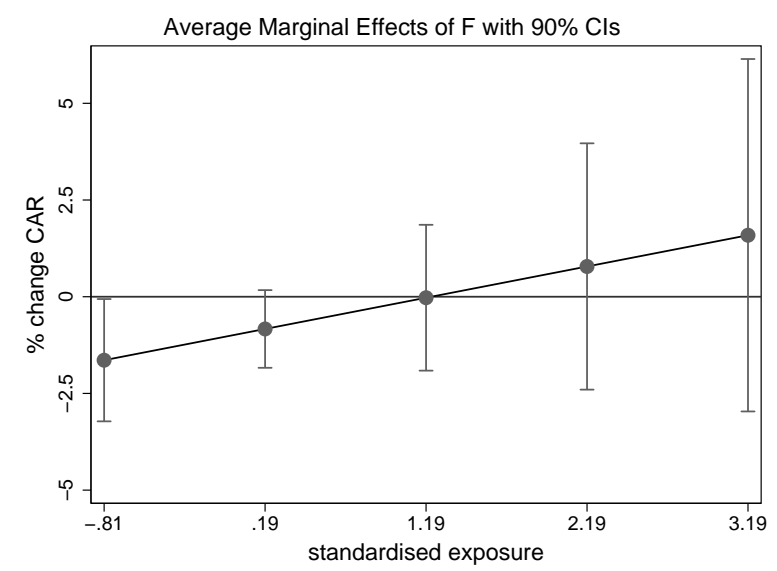

(a) Negative sentiment (CAR[-1,1])

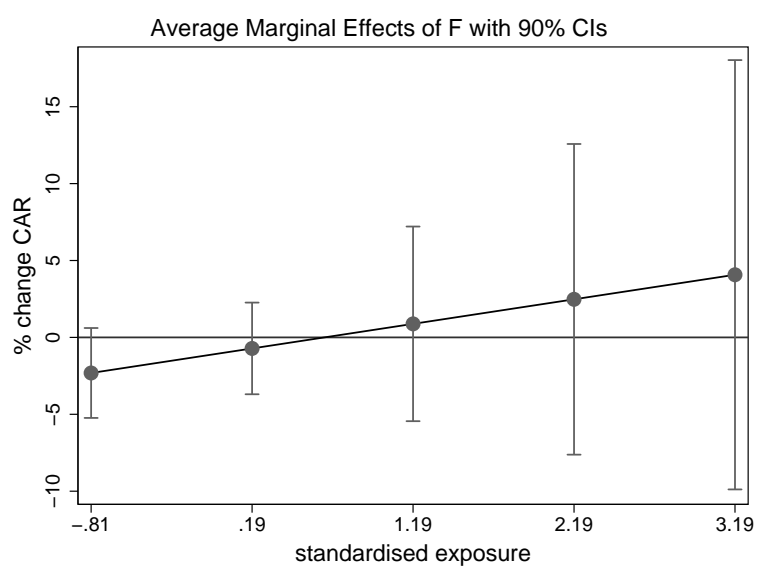

(c) Negative sentiment (CAR[-10,10])

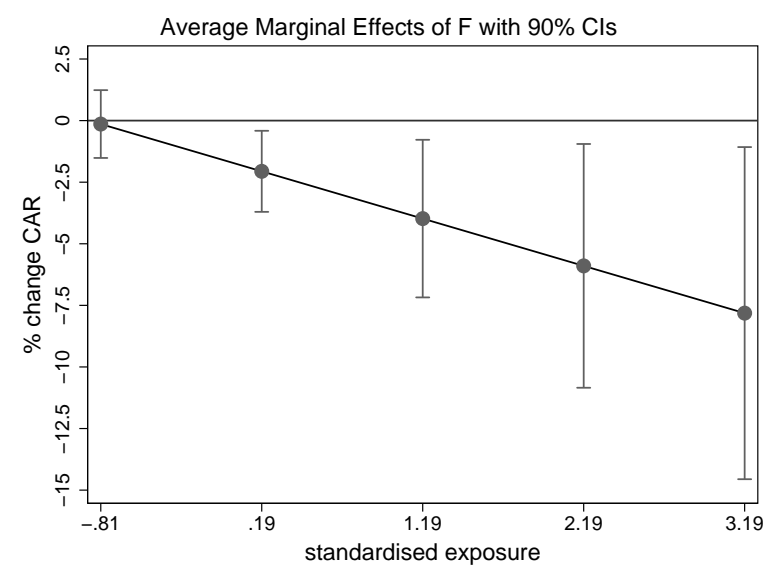

(b) Neutral/Positive sentiment (CAR[-1,1])

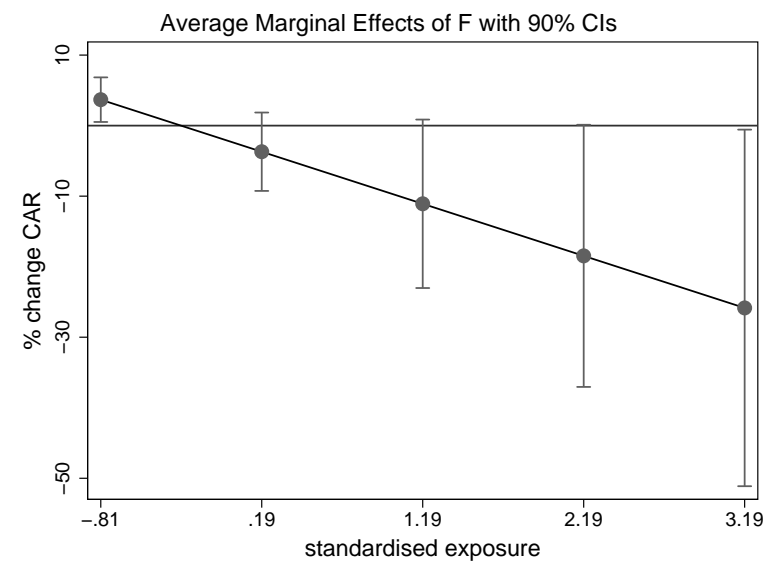

(d) Neutral/Positive sentiment (CAR[-10,10])

Figure C.1: Marginal effects (\% change in CAR) of a 1 standard deviation increase in fine (standardised), as a function of media exposure - manufacturing cartels only. Notes: The figures show how the marginal effect of fine on CAR changes for different levels of media exposure and sentiment. The panels on the left are calculated at a negative value of sentiment ( $5^{t h}$ percentile of the sentiment distribution). The panels on the right are calculated at a neutral/positive value of sentiment $\left(95^{\text {th }}\right.$ percentile of the sentiment distribution). The top panel depicts the effect on the proximity of the decision; the bottom panel depicts the effect around a wider time window. 


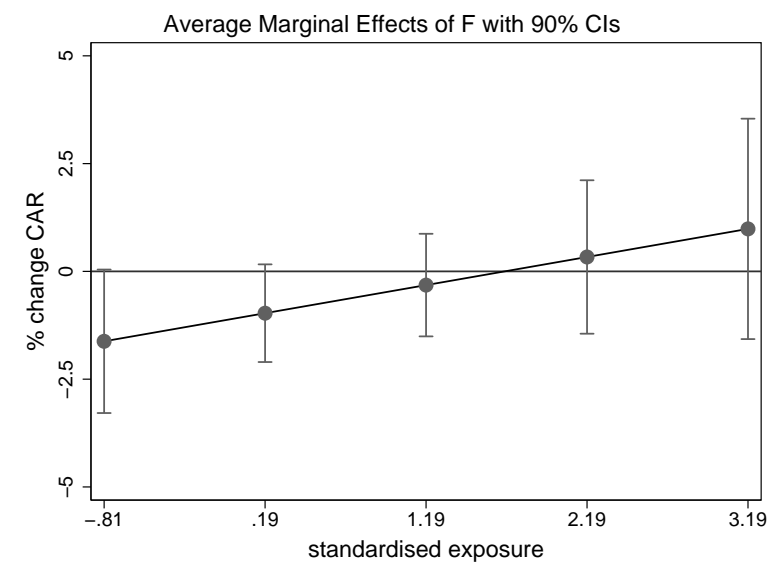

(a) Negative sentiment (CAR[-1,1])

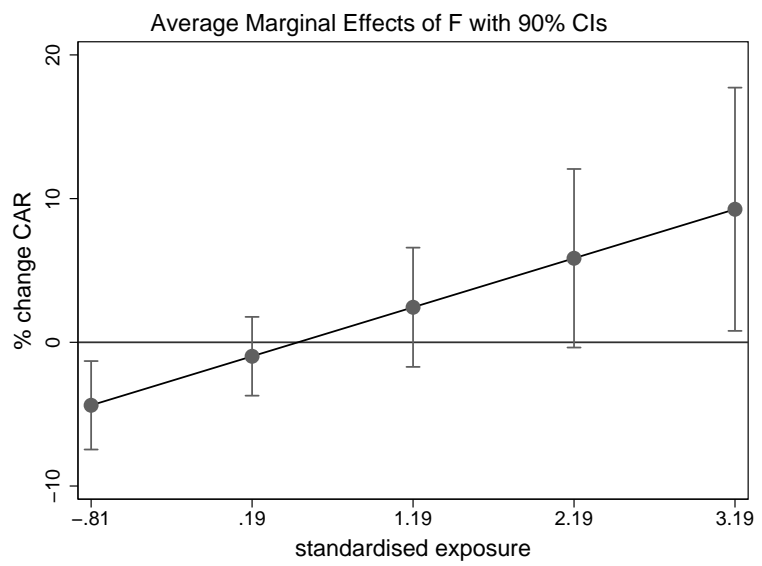

(c) Negative sentiment (CAR[-10,10])

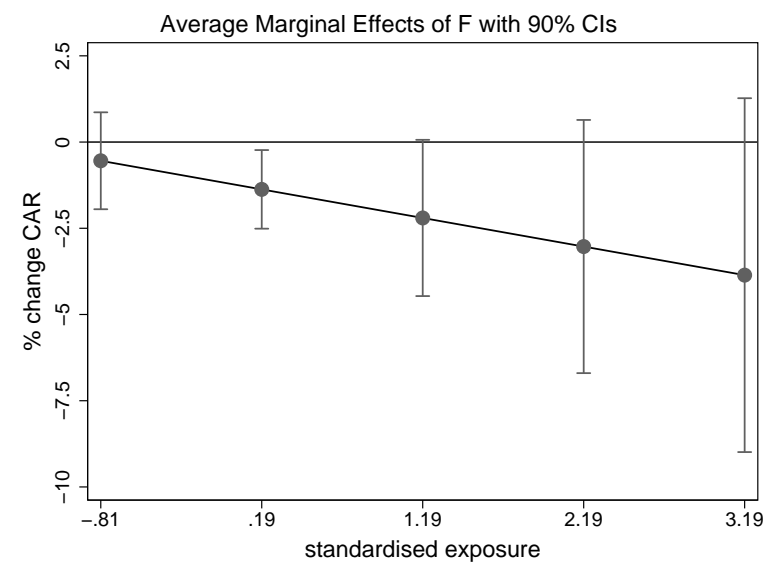

(b) Neutral/Positive sentiment (CAR[-1,1])

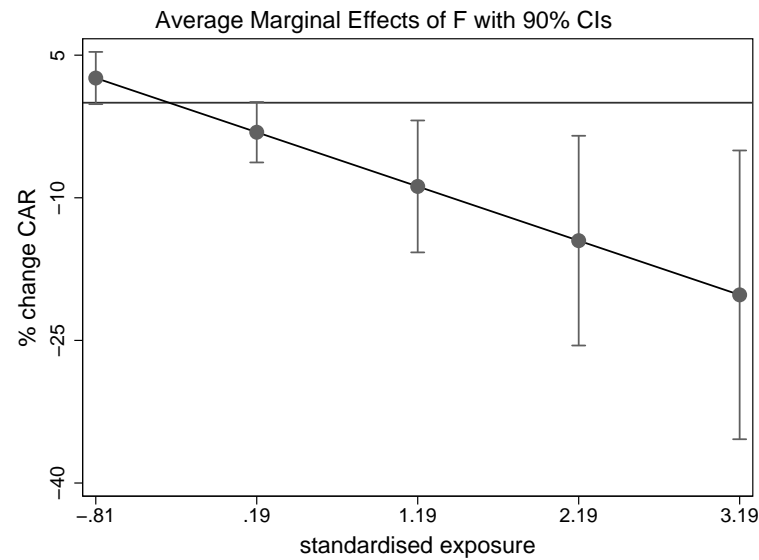

(d) Neutral/Positive sentiment (CAR[-10,10])

Figure C.2: Marginal effects (\% change in CAR) of a 1 standard deviation increase in fine (standardised), as a function of media exposure - squared custom sentiment score. Notes: The figures show how the marginal effect of fine on CAR changes for different levels of media exposure and sentiment. The panels on the left are calculated at a negative value of sentiment $\left(5^{\text {th }}\right.$ percentile of the sentiment distribution). The panels on the right are calculated at a neutral/positive value of sentiment $\left(95^{\text {th }}\right.$ percentile of the sentiment distribution). The top panel depicts the effect on the proximity of the decision; the bottom panel depicts the effect around a wider time window. 


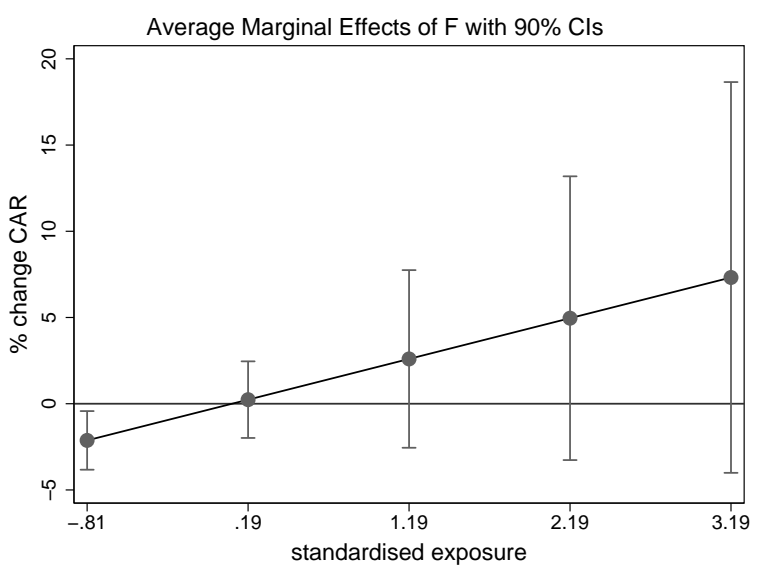

(a) Negative sentiment (CAR[-1,1])

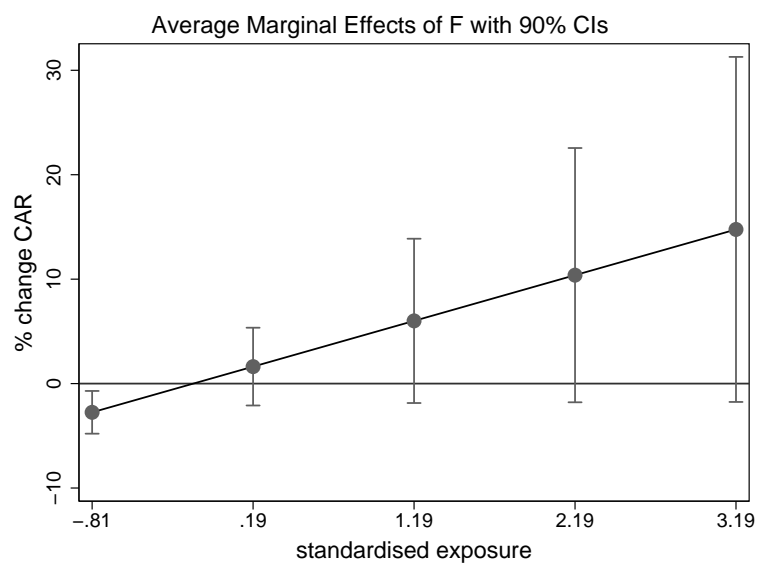

(c) Negative sentiment (CAR[-10,10])

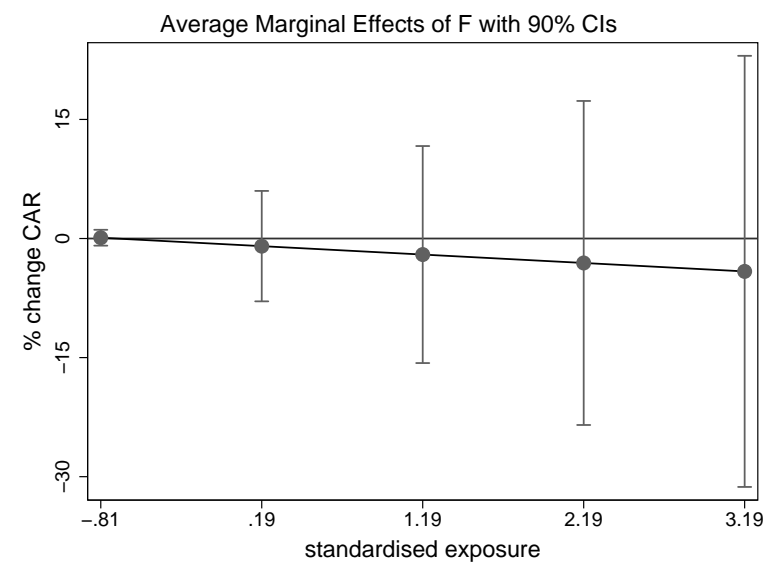

(b) Neutral/Positive sentiment (CAR[-1,1])

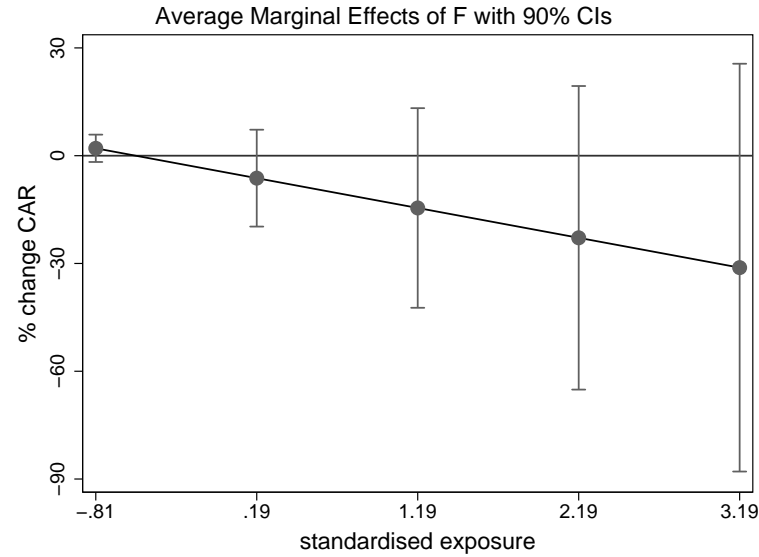

(d) Neutral/Positive sentiment (CAR[-10,10])

Figure C.3: Marginal effects (\% change in CAR) of a 1 standard deviation increase in fine (standardised), as a function of media exposure - cartels convicted before 2005. Notes: The figures show how the marginal effect of fine on CAR changes for different levels of media exposure and sentiment. The panels on the left are calculated at a negative value of sentiment ( $5^{\text {th }}$ percentile of the sentiment distribution). The panels on the right are calculated at a neutral/positive value of sentiment $\left(95^{t h}\right.$ percentile of the sentiment distribution). The top panel depicts the effect on the proximity of the decision; the bottom panel depicts the effect around a wider time window. 


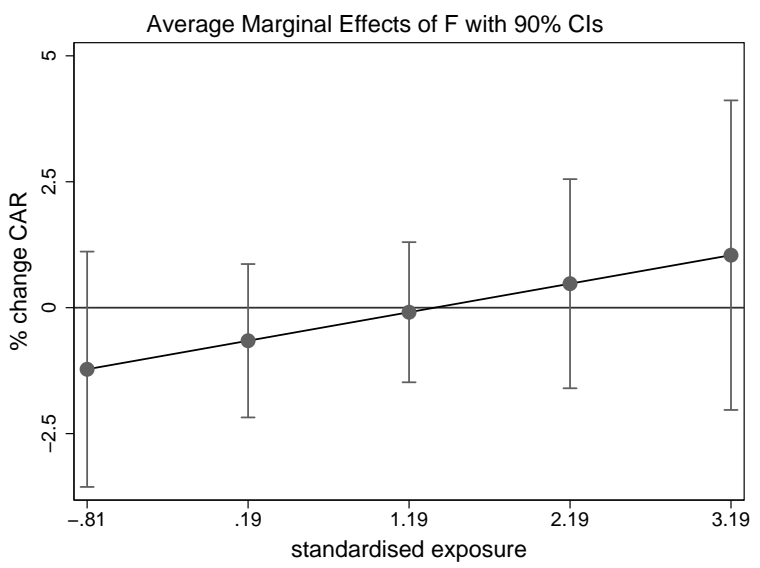

(a) Negative sentiment (CAR[-1,1])

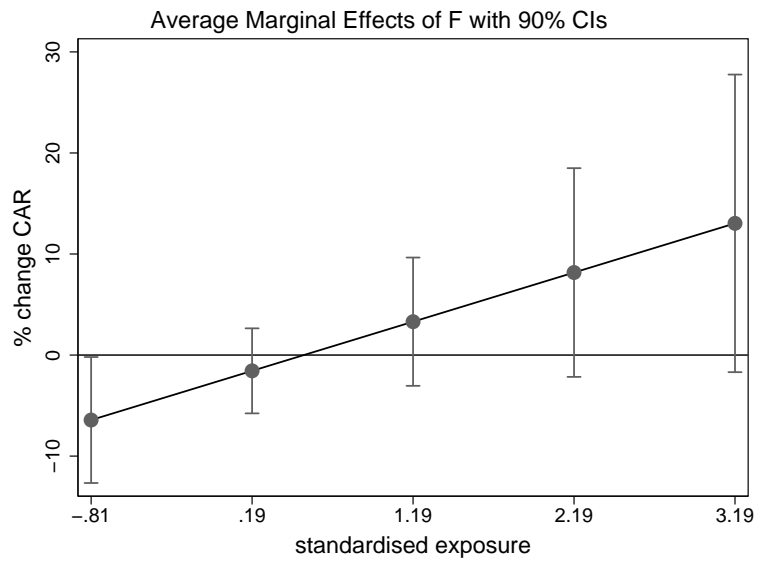

(c) Negative sentiment (CAR[-10,10])

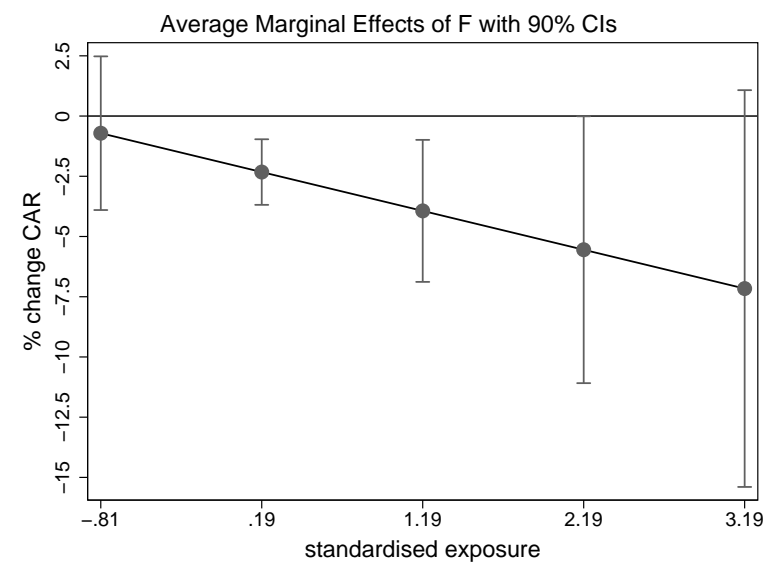

(b) Neutral/Positive sentiment (CAR[-1,1])

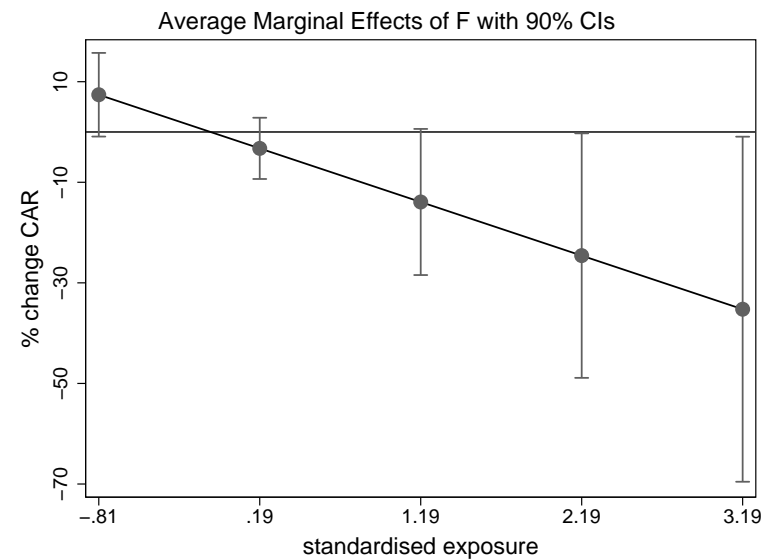

(d) Neutral/Positive sentiment (CAR[-10,10])

Figure C.4: Marginal effects (\% change in CAR) of a 1 standard deviation increase in fine (standardised), as a function of media exposure - cartels convicted after 2004. Notes: The figures show how the marginal effect of fine on CAR changes for different levels of media exposure and sentiment. The panels on the left are calculated at a negative value of sentiment $\left(5^{\text {th }}\right.$ percentile of the sentiment distribution). The panels on the right are calculated at a neutral/positive value of sentiment $\left(95^{\text {th }}\right.$ percentile of the sentiment distribution). The top panel depicts the effect on the proximity of the decision; the bottom panel depicts the effect around a wider time window. 


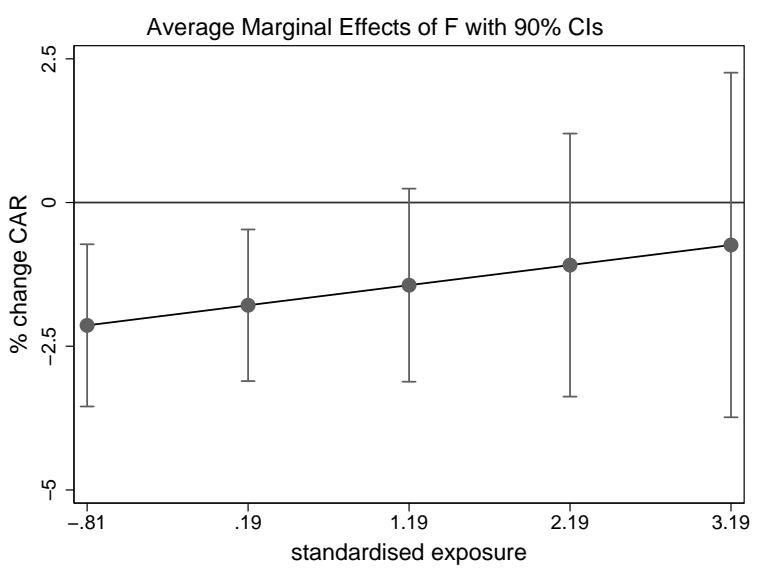

(a) Negative sentiment (CAR[-1,1])

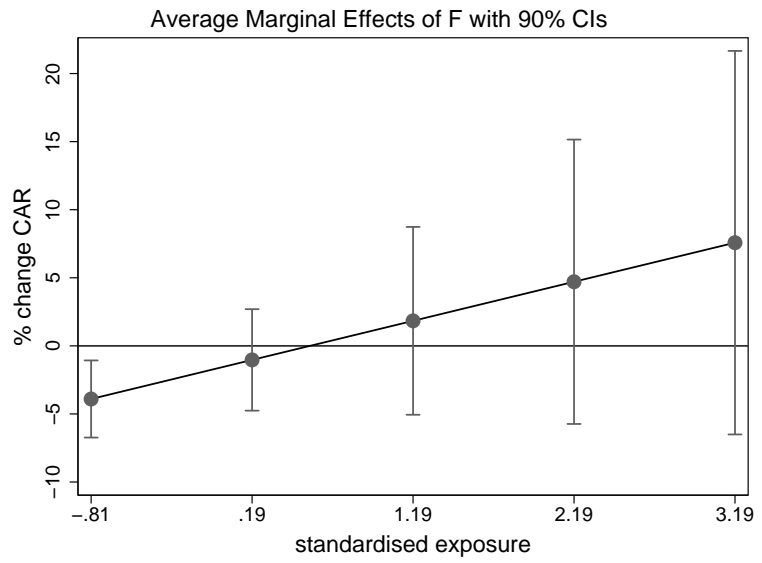

(c) Negative sentiment (CAR[-10,10])

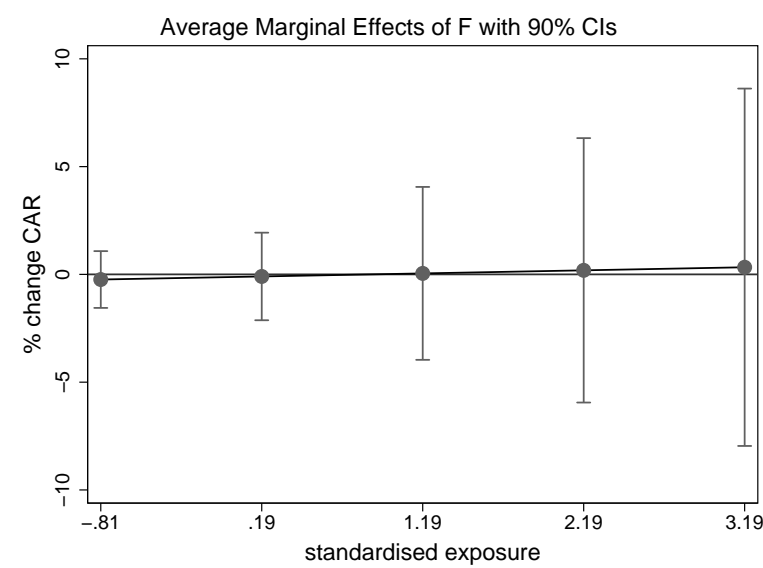

(b) Neutral/Positive sentiment (CAR[-1,1])

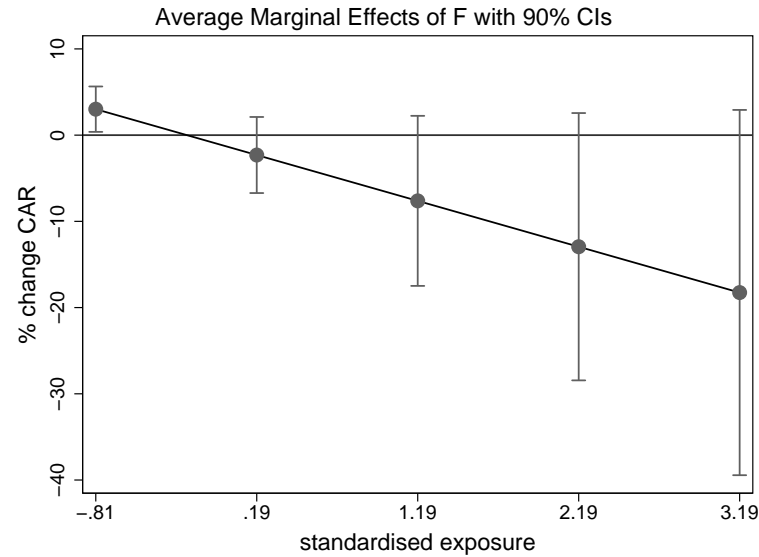

(d) Neutral/Positive sentiment (CAR[-10,10])

Figure C.5: Marginal effects (\% change in CAR) of a 1 standard deviation increase in fine (standardised), as a function of media exposure - custom sentiment score weighted by news circulation). Notes: The figures show how the marginal effect of fine on CAR changes for different levels of media exposure and sentiment. The panels on the left are calculated at a negative value of sentiment $\left(5^{\text {th }}\right.$ percentile of the sentiment distribution). The panels on the right are calculated at a neutral/positive value of sentiment $\left(95^{t h}\right.$ percentile of the sentiment distribution). The top panel depicts the effect on the proximity of the decision; the bottom panel depicts the effect around a wider time window. 


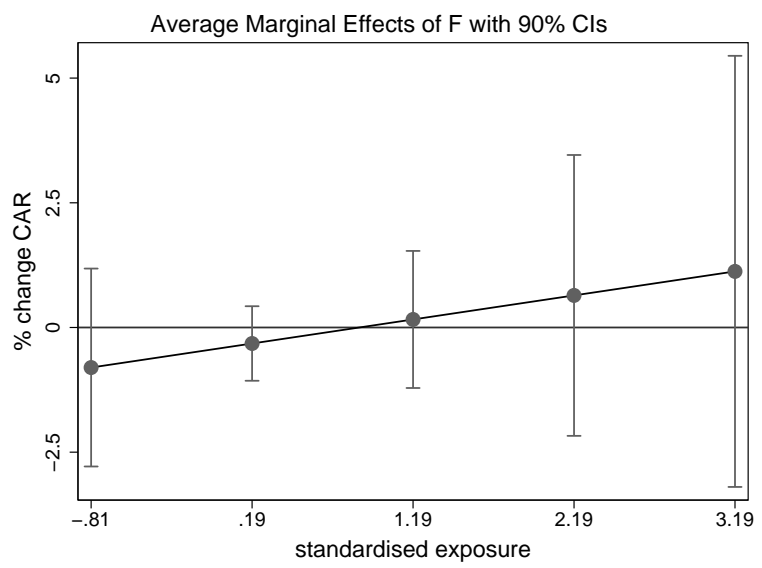

(a) Negative sentiment (CAR[-1,1])

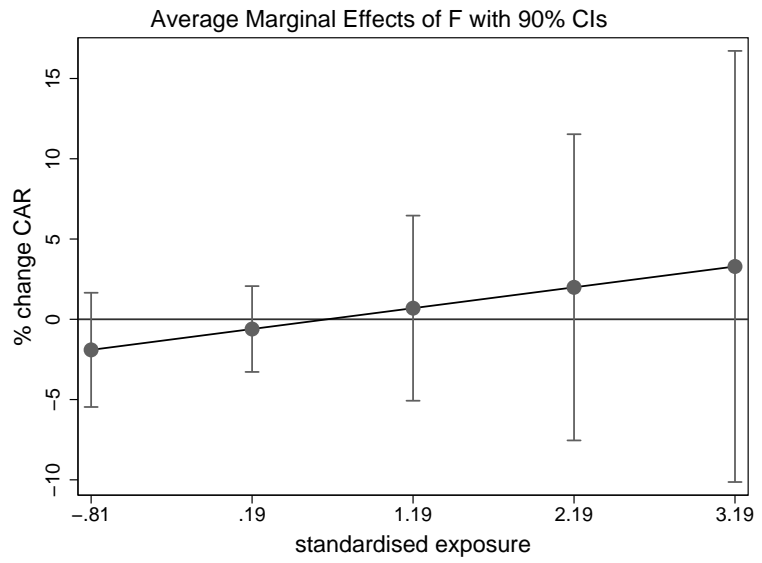

(c) Negative sentiment (CAR[-10,10])

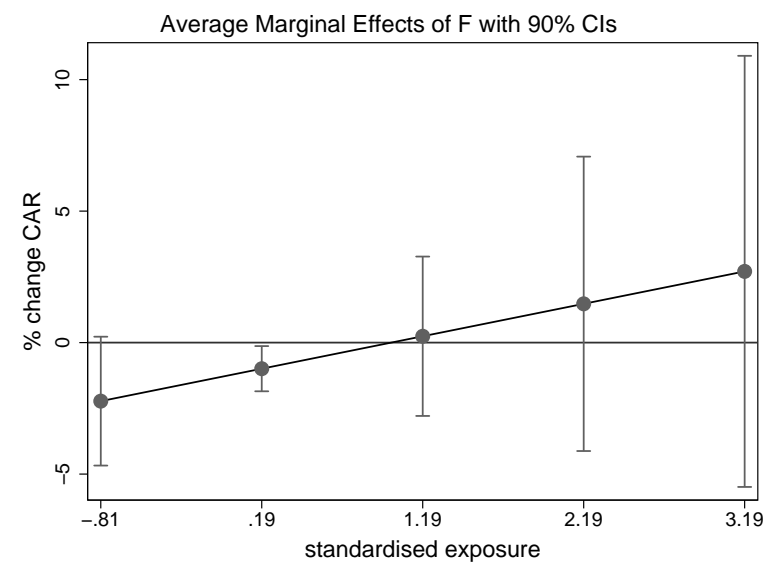

(b) Neutral/Positive sentiment (CAR[-1,1])

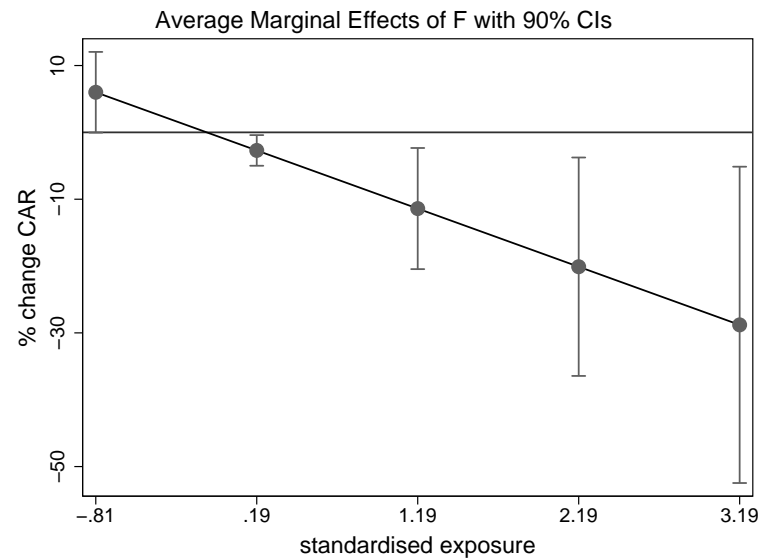

(d) Neutral/Positive sentiment (CAR[-10,10])

Figure C.6: Marginal effects (\% change in CAR) of a 1 standard deviation increase in fine (standardised), as a function of media exposure - cartels with leq 9 members. Notes: The figures show how the marginal effect of fine on CAR changes for different levels of media exposure and sentiment. The panels on the left are calculated at a negative value of sentiment $\left(5^{\text {th }}\right.$ percentile of the sentiment distribution). The panels on the right are calculated at a neutral/positive value of sentiment $\left(95^{\text {th }}\right.$ percentile of the sentiment distribution). The top panel depicts the effect on the proximity of the decision; the bottom panel depicts the effect around a wider time window. 


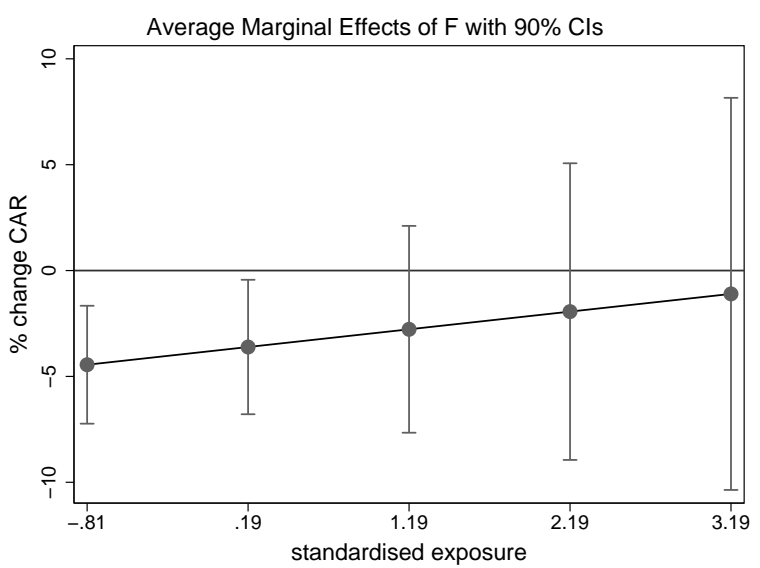

(a) Negative sentiment (CAR[-1,1])

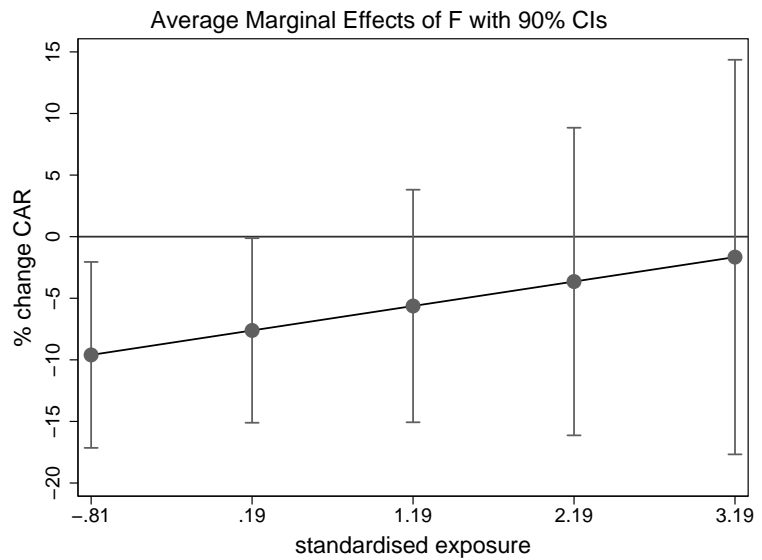

(c) Negative sentiment (CAR[-10,10])

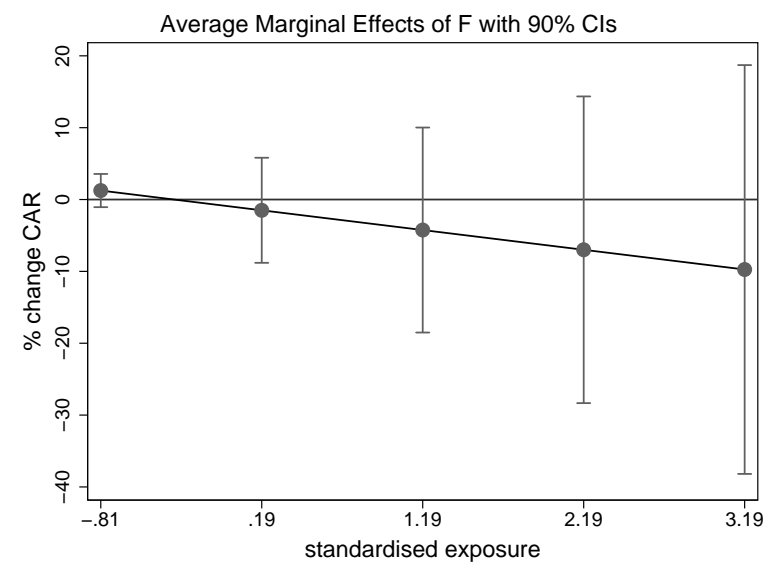

(b) Neutral/Positive sentiment (CAR[-1,1])

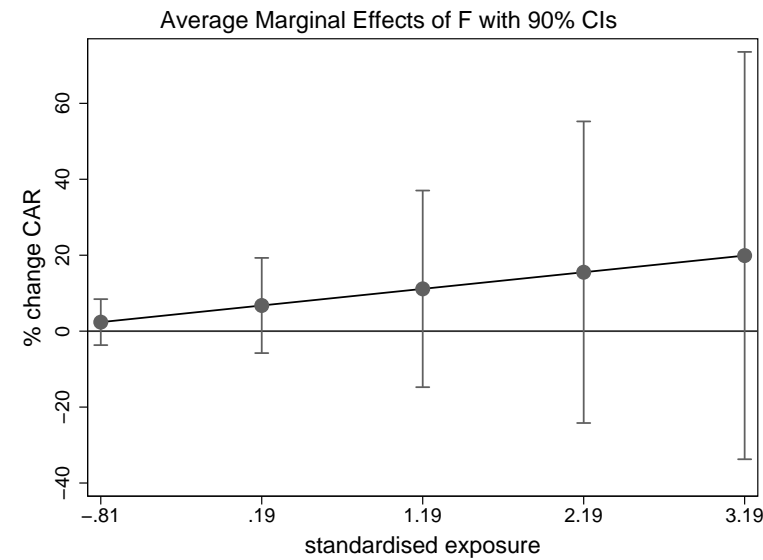

(d) Neutral/Positive sentiment (CAR[-10,10])

Figure C.7: Marginal effects (\% change in CAR) of a 1 standard deviation increase in fine (standardised), as a function of media exposure - cartels with $>9$ members. Notes: The figures show how the marginal effect of fine on CAR changes for different levels of media exposure and sentiment. The panels on the left are calculated at a negative value of sentiment ( $5^{t h}$ percentile of the sentiment distribution). The panels on the right are calculated at a neutral/positive value of sentiment $\left(95^{\text {th }}\right.$ percentile of the sentiment distribution). The top panel depicts the effect on the proximity of the decision; the bottom panel depicts the effect around a wider time window. 


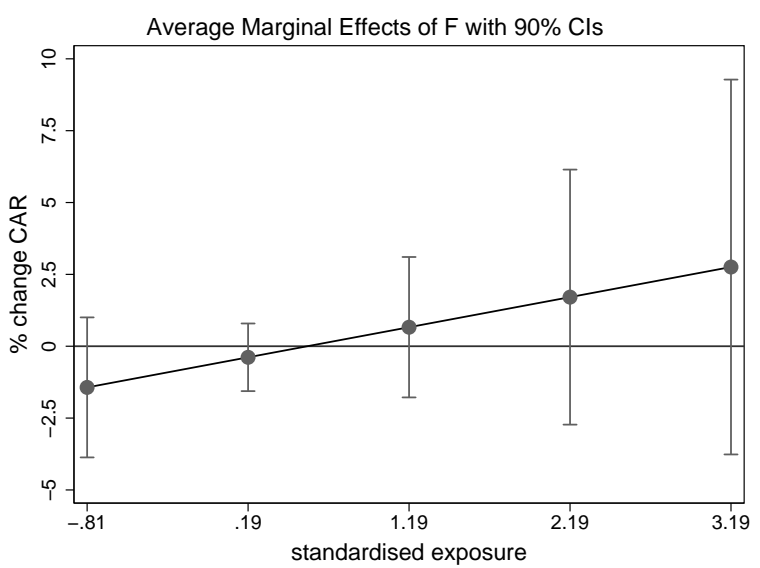

(a) Negative sentiment (CAR[-1,1])

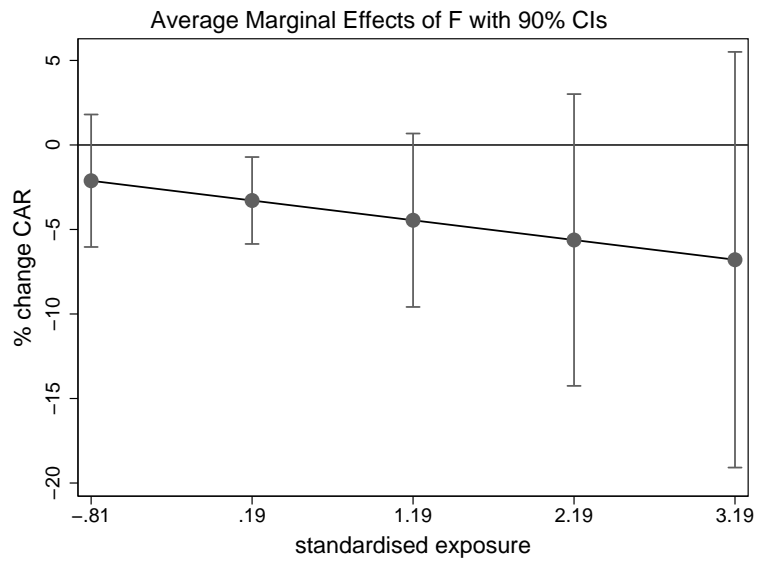

(c) Negative sentiment (CAR[-10,10])

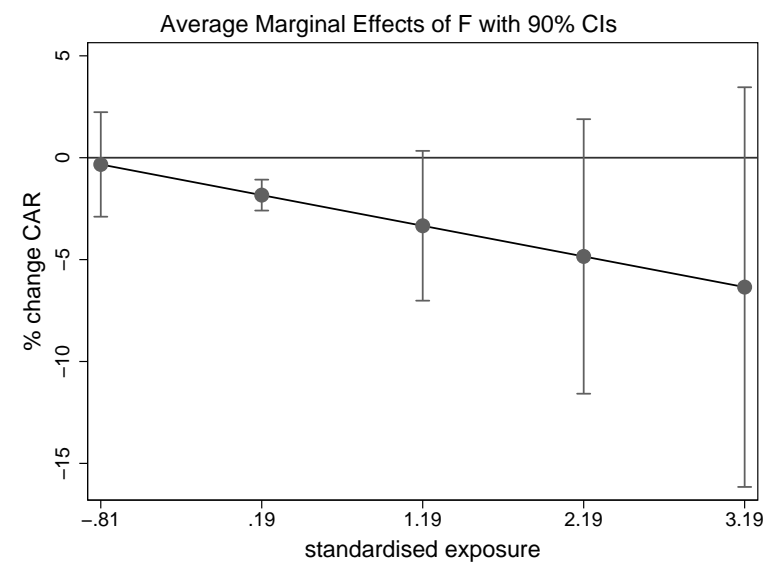

(b) Neutral/Positive sentiment (CAR[-1,1])

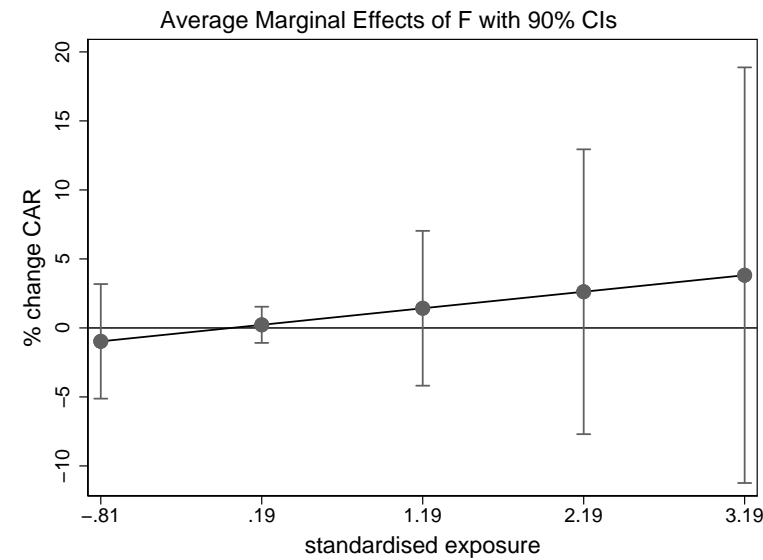

(d) Neutral/Positive sentiment (CAR[-10,10])

Figure C.8: Marginal effects (\% change in CAR) of a 1 standard deviation increase in fine (standardised), as a function of media exposure - excluding bid-rigging cartels. Notes: The figures show how the marginal effect of fine on CAR changes for different levels of media exposure and sentiment. The panels on the left are calculated at a negative value of sentiment ( $5^{\text {th }}$ percentile of the sentiment distribution). The panels on the right are calculated at a neutral/positive value of sentiment $\left(95^{t h}\right.$ percentile of the sentiment distribution). The top panel depicts the effect on the proximity of the decision; the bottom panel depicts the effect around a wider time window. 


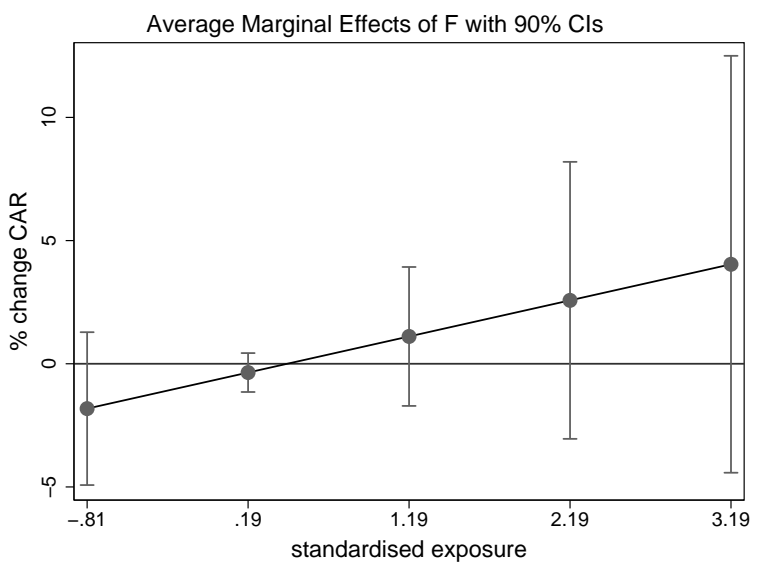

(a) Negative sentiment (CAR[-1,1])

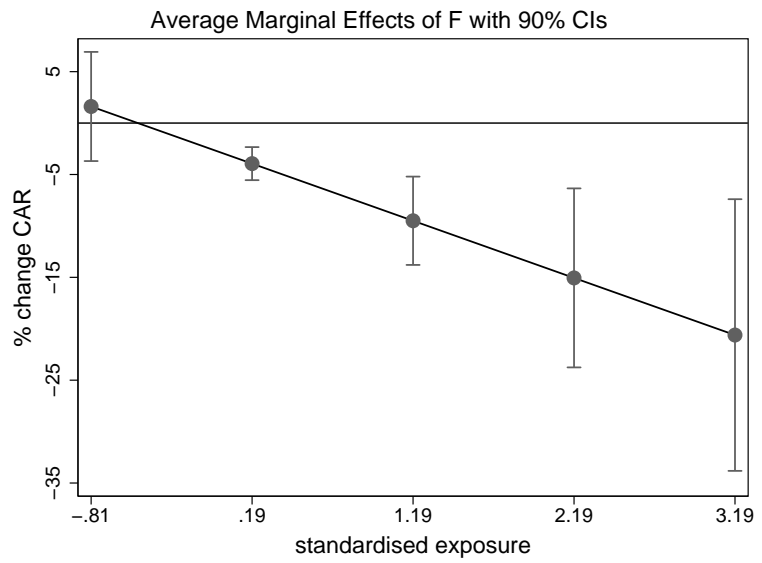

(c) Negative sentiment (CAR[-10,10])

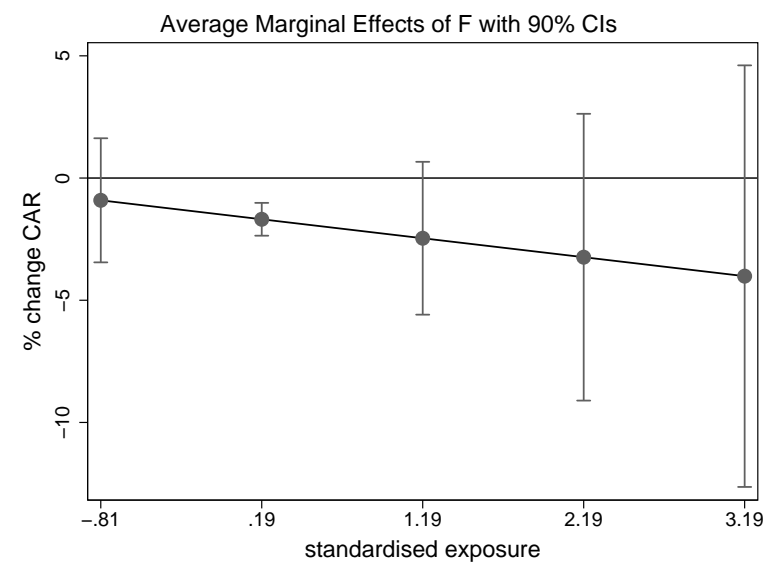

(b) Neutral/Positive sentiment (CAR[-1,1])

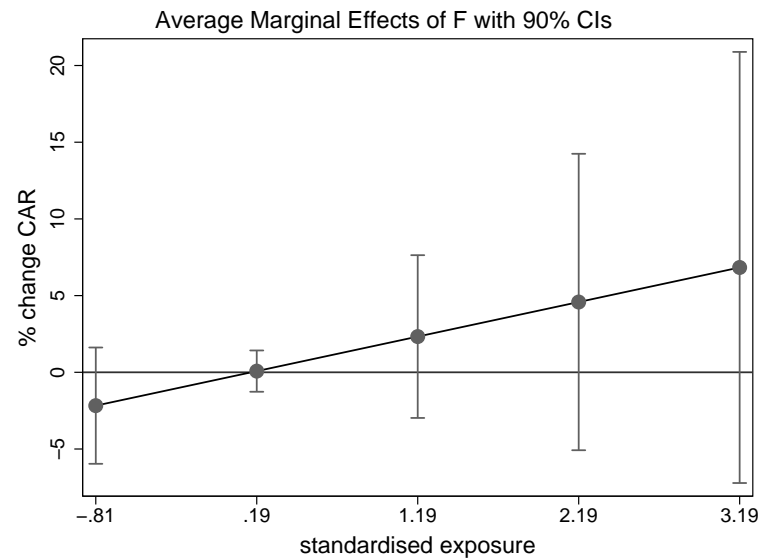

(d) Neutral/Positive sentiment (CAR[-10,10])

Figure C.9: Marginal effects (\% change in CAR) of a 1 standard deviation increase in fine (standardised), as a function of media exposure - excluding cartels with a ring-leader. Notes: The figures show how the marginal effect of fine on CAR changes for different levels of media exposure and sentiment. The panels on the left are calculated at a negative value of sentiment ( $5^{\text {th }}$ percentile of the sentiment distribution). The panels on the right are calculated at a neutral/positive value of sentiment $\left(95^{\text {th }}\right.$ percentile of the sentiment distribution). The top panel depicts the effect on the proximity of the decision; the bottom panel depicts the effect around a wider time window. 


\section{Creation of the sentiment scores}

For each token (unigram, bigram or trigram) we surveyed 10 colleagues at the Centre for Competition Policy (including Mariuzzo and Ormosi), to acquire a simple lexicon of sentiment scores $-1,0,1$ indicating whether the reader thinks a given token is negative, neutral, or positive. Table D.13 shows a sample of our custom lexicon. We then took the mode sentiment score for each token. The words and the mode sentiment score was then added to the general sentiment dictionary.

Table D.13: Sample custom lexicon scores.

\begin{tabular}{|c|c|c|c|c|c|c|c|c|c|c|c|c|c|}
\hline count & n-gram & frequency & a1 & $\mathrm{a} 2$ & a3 & a4 & a5 & a6 & a7 & $\mathrm{a} 8$ & a9 & a10 & mode \\
\hline 1 & cartel & 16379 & -1 & -1 & -1 & -1 & -1 & -1 & -1 & 0 & -1 & -1 & -1 \\
\hline 2 & fined & 9666 & -1 & -1 & -1 & -1 & -1 & -1 & -1 & -1 & -1 & -1 & -1 \\
\hline 3 & fines & 8812 & -1 & -1 & -1 & -1 & 0 & 0 & -1 & 0 & -1 & 0 & -1 \\
\hline 4 & competition & 5857 & 1 & 1 & 1 & 1 & 1 & 1 & 1 & 1 & 1 & 1 & 1 \\
\hline 5 & market & 4308 & 0 & 0 & 0 & 0 & 0 & 0 & 0 & 0 & 0 & 0 & 0 \\
\hline 6 & price & 3818 & 0 & 0 & 0 & 0 & 0 & 0 & 0 & 0 & 0 & 0 & 0 \\
\hline 7 & cartels & 3138 & -1 & -1 & -1 & -1 & -1 & -1 & -1 & -1 & -1 & -1 & -1 \\
\hline 8 & pay & 2994 & 0 & 0 & -1 & 0 & 0 & 0 & 0 & 0 & 0 & 0 & 0 \\
\hline 9 & imposed & 2971 & -1 & 0 & -1 & -1 & -1 & -1 & -1 & -1 & -1 & -1 & -1 \\
\hline 10 & decision & 2916 & 0 & 0 & -1 & 0 & 0 & 0 & 0 & 0 & 0 & 0 & 0 \\
\hline 11 & investigation & 2864 & 0 & 0 & -1 & 0 & 0 & 0 & 0 & 0 & 0 & 0 & 0 \\
\hline 12 & information & 2754 & 0 & 0 & 0 & 0 & 0 & 0 & 0 & 0 & 0 & 0 & 0 \\
\hline 13 & commissioner & 2603 & 0 & 0 & 0 & 0 & 0 & 0 & 1 & 0 & 0 & 0 & 0 \\
\hline 14 & used & 2427 & 0 & 0 & 0 & 0 & 0 & 0 & -1 & 0 & 0 & -1 & 0 \\
\hline 15 & involved & 2233 & 0 & 0 & -1 & 0 & 0 & 0 & 0 & 0 & 0 & 0 & 0 \\
\hline 16 & pricefixing & 2076 & -1 & -1 & -1 & -1 & -1 & -1 & -1 & -1 & -1 & -1 & -1 \\
\hline
\end{tabular}

Notes: The table shows the most frequent unigram tokens in our sample of cartel news articles, and the corresponding scores given by our colleagues who are specialised in the area of competition policy. The full table is available here: https://github.com/Peterormosi/ private_v_public_sanctions

We used the R package sentimentr to then calculate the polarity (sentiment) scores for each newspaper article. The following discussion draws on the manual of the relevant $\mathrm{R}$ package. ${ }^{31}$ The equation used by the algorithm to assign value to polarity of each news item first takes the above lexicon to tag polarised words. Each news item $i$ is broken into sentences $s_{i}=\left\{s_{i, 1}, s_{i, 2}, \cdots, s_{i, n_{i}}\right\}$, and each sentence $j$ is further broken down into an ordered bag of words $w_{i, j}=\left\{w_{i, j, 1}, w_{i, j, 2}, \cdots, w_{i, j, n_{i, j}}\right\}$. Punctuation is removed with the exception of pause punctuations (commas, colons, semicolons) which are considered a word within the sentence (denote these pause words as $c w$ ). Each word $k$ is then represented as $w_{i, j, k}$; e.g. $w_{3,2,5}$ would be the fifth word of the second sentence of the third news item. The words in each sentence are searched and compared to a dictionary of polarised words. Positive $\left(w_{i, j, k^{+}}\right)$and negative $\left(w_{i, j, k^{-}}\right)$words are tagged with $\mathrm{a}+1$ and -1 respectively (denote polarised words as $p w$ ). These form a polar cluster $\left(c_{i, j, k}\right)$ which is a subset of the words in the sentence $s_{i, j}$.

The polarized context cluster of words $\left(c_{i, j, k}\right)$ is pulled from around the polarised words $(p w)$ and defaults to four words before and two words after the $p w$ to be considered as valence shifters. The cluster can be represented as $\left(c_{i, j, k}=p w_{i, j, k-n b}, \ldots, p w_{i, j, k}, \ldots, p w_{i, j, k+n a}\right)$, where $n b$ and $n a$ are the parameters $n . b e f o r e$ and n.after. The words in this polarised context cluster are tagged as neutral $\left(w_{i, j, k}^{0}\right)$, negator $\left(w_{i, j, k}^{n}\right)$, amplifier (intensifier) $\left(w_{i, j, k}^{a}\right)$, or de-amplifier (downtoner) $\left(w_{i, j, k}^{d}\right)$. Neutral words hold no value in the equation but do affect word count. Each polarised word is then weighted by the function and number of the valence shifters directly surrounding the positive or negative polarity word. Pause $(\mathrm{cw})$ locations

${ }^{31}$ https://rdrr.io/cran/sentimentr/man/sentiment.html 
(punctuation that denotes a pause including commas, colons, and semicolons) are indexed and considered in calculating the upper and lower bounds in the polarized context cluster. This is because these marks indicate a change in thought, and words prior are not necessarily connected with words after these punctuation marks.

The core value in the cluster of the polarised word is acted upon by valence shifters. Amplifiers (intensifiers) increase the polarity. Amplifiers become de-amplifiers if the context cluster contains an odd number of negators. De-amplifiers (downtoners) work to decrease the polarity. Negation acts on amplifiers/deamplifiers as discussed but also flips the sign of the polarised word. Negation is determined by raising -1 to the power of the number of negators. Simply, this is a result of the assumption that two negatives equal a positive, three negatives a negative and so on.

The adversative conjunctions (i.e., 'but', 'however', and 'although') also weight the context cluster. An adversative conjunction before the polarized word up-weights the cluster, whereas an adversative conjunction after the polarized word down-weights the cluster. This corresponds to the belief that an adversative conjunction makes the next clause of greater values while lowering the value placed on the prior clause. Finally, the weighted context clusters are summed and divided by the square root of the word count yielding an unbounded polarity score $(C)$ for each sentence and for each news item.

For demonstration, take the following two stylised examples: (1) British Airways formed a cartel with its competitors, and (2) British Airways did not form a cartel with its competitors. The first sentence is 8 words long, and, according to our lexicon, contains one negative word, 'cartel'. There are no valence shifters or adversative conjunctions, therefore the polarity score is: $C=-1 / \sqrt{8}=-0.35$. The second sentence is 10 words long, there is one negative word, 'cartel', but there is a valence shifter (a negation), and no adversarial conjunction, therefore the polarity score is: $C=-(-1 / \sqrt{10})=0.32$.

To give an example from our sample, regarding the Airfreight cartel, Agence France Presse reported the following: Australia's Qantas on Wednesday acknowledged improper conduct in its freight division, after a European watchdog fined it and 10 other airlines 1.1 billion US dollars for price-fixing. The European Commission (EC) hit 11 carriers, including Air France-KLM, British Airways and Japan Airlines, with fines of between 8.2 million and 310 million euros Tuesday for running a global cargo cartel from 1999 to 2006. It is deplorable that so many major airlines coordinated their pricing to the detriment of European businesses and European consumers, competition commissioner Joaquin Almunia said. \%Qantas said its share of the fine for price-fixing conduct within its freight division between 2000 and 2006 was 8.8 million euros (12.1 million US dollars), adding it would consider in detail the EC's full decision when it was received next week. We have acknowledged the improper conduct by the Qantas Freight division over this period, a spokesman for the airline said. Qantas was a leniency applicant and we have fully cooperated with the EC. We have also cooperated fully with all other global regulators. The fine comes three years after Qantas was fined 40 million US dollars for price-fixing in the North American air cargo market. \%And it follows a decision by Australia's competition watchdog to fine Qantas 20 million dollars over the same cartel. The European Commission said the cargo carriers coordinated their action on surcharges for fuel and security without discounts over a six-year period. The commission said it dropped charges against another 11 carriers and one consultancy firm which it did not name. Air New Zealand said it was one of the airlines the EC had dropped the charges against, describing the decision as positive. The carrier refused to comment on why the case against it was dropped.

The text can be tokenised into 11 sentences. The table below summarises the polarity score calculations for each sentence, and the mean across all sentences, which is what we use as the news item polarity score. 
Table D.14: Polarity score - example

\begin{tabular}{rrllr}
\hline sentence\# & word count & positive words & negative words & polarity \\
\hline 1 & 25 & - & improper, fined, pricefixing & -0.60 \\
2 & 31 & - & fines, cartel & -0.36 \\
3 & 25 & competition & deplorable, detriment & -0.20 \\
4 & 20 & - & improper & -0.22 \\
5 & 13 & leniency, cooperated & - & 0.55 \\
6 & 10 & cooperated & - & 0.32 \\
7 & 21 & fine & fined, pricefixing & -0.22 \\
8 & 22 & - & carriers coordinated, surcharges & -0.64 \\
9 & 18 & - & - & 0 \\
10 & 22 & positive & - & 0.21 \\
11 & 13 & - & refused & -0.28 \\
\hline News item level score: & & -0.13 \\
\hline
\end{tabular}

